\title{
Traditional Food Crop Production and Marketing in Sub-Saharan Africa: The Case of Finger Millet in Western Kenya
}

\author{
Dissertation \\ zur Erlangung des Doktorgrades \\ der Fakultät für Agrarwissenschaften \\ der Georg-August-Universität Göttingen
}

vorgelegt von

Christina Handschuch,

geboren in Oldenburg

Göttingen, Februar 2014 
1. Referentin: Prof. Dr. Meike Wollni

2. Korreferent: Prof. Dr. Matin Qaim

Tag der mündlichen Prüfung: 13. Februar 2014 


\section{Summary}

Despite remarkable advances, overcoming rural poverty and food insecurity in developing countries remains one of the biggest challenges of the $21^{\text {st }}$ century. Increasing production and income opportunities in the agricultural sector is one of the key factors to achieve these goals. While researchers and policy makers have not paid a lot of attention to traditional food crops like millets, fonio, or tef in the past decades, these crops could make a valuable contribution to poverty alleviation and food security in many regions of the developing world.

In this dissertation we examine the potential and constraints in the production and marketing of the traditional food crop finger millet in western Kenya. Finger millet (Eleusine coracana) used to be one of the most important food crops in western Kenya, but was almost completely replaced by maize over the past century. While maize offers a higher yield potential and requires less labor input than finger millet, the limits of a maize-based production system and maize-based diets have become visible over the past decades. Maize yields have been stagnating or declining due to increasingly erratic rainfall patterns and ongoing soil erosion. Furthermore, maize-based diets have led to widespread micronutrient deficiencies in the region. Finger millet is not only more nutritious than maize, but also better adapted to poor soils and erratic weather conditions. In addition, finger millet prices have been far higher than maize prices over the past years.

The analyses of the present dissertation are based on household data from 270 finger millet producers that was collected in western Kenya in 2012. In a first part of our empirical analysis, we examine the determinants of the adoption of improved agricultural practices in finger millet and maize production and their effect on finger millet yields. In a second part, we assess the factors that influence market participation of small-scale farmers and the selling prices obtained by the farmers. Finally, we compare the profitability and the technical efficiency estimates of finger millet and maize production and assess the factors that influence the efficiency in the production of the two crops.

Adoption of improved agricultural practices is essential to achieve production and productivity increases in the agricultural sector. We estimate a multivariate probit model to analyze the factors that influence the adoption of modern varieties and chemical fertilizer in finger millet and maize production. The results show that social networks and connectedness have a strong impact on the adoption of improved finger millet practices, but are of marginal importance in the adoption of improved maize practices. These findings reflect the sparse availability of information and modern seeds in the case of finger millet, which makes connectedness, e.g. through participation in village groups, ownership of a cell phone, or access to extension services, more important in the adoption 
process. A Cobb-Douglas production function demonstrates that modern varieties and chemical fertilizer significantly increase finger millet yields.

Besides increasing agricultural production, increasing farm incomes is a key to lift small-scale farmers out of poverty. The poorest and least endowed farmers are often excluded from agricultural markets, especially high-value agricultural markets, due to high transaction costs. Furthermore, female farmers often face particularly high market barriers, e.g. due to a weak bargaining position. A probit model on the households' decision to market finger millet shows that there are no particular market barriers for poor households or female producers in the case of finger millet. However, the selling price varies greatly between households. A linear regression model on selling prices shows that female farmers face price disadvantages unless they are organized in groups.

To assess whether finger millet is an economically viable cropping alternative to maize, we compare the per-acre profitability of finger millet and maize. As long as labor opportunity costs are not taken into account, the per-acre profits obtained from finger millet and maize production do not differ substantially. However, accounting for labor opportunity costs, maize profits are more than twice as large as finger millet profits. We estimate the technical efficiency in finger millet and maize production using a stochastic frontier approach. For both crops, the average technical efficiency is substantially lower than the technical efficiency of the best performing farms. However, the efficiency gap is considerably higher in finger millet production. Results of the efficiency equation show that in the case of finger millet, group membership increases efficiency, while female farmers produce less efficiently than male farmers on the average.

We conclude that a mix of technological and institutional changes is necessary to make finger millet more attractive to the farmers. In terms of technology, the yield potential has to be increased and the labor requirements decreased. In terms of institutions, social networks such as village groups are of particular importance in the production of traditional food crops and foster the adoption of improved and more efficient production technologies. Village groups are of particular importance for female farmers, who face larger challenges in the production and marketing of finger millet than their male counterparts. 


\section{Zusammenfassung}

Trotz beachtlicher Fortschritte bleibt die Bekämpfung von Hunger und extremer Armut in Entwicklungsländern eine der größten Herausforderungen des 21. Jahrhunderts. Insbesondere in ländlichen Gebieten gehören Produktionssteigerungen und eine Verbesserung der Einkommensmöglichkeiten in der Landwirtschaft zu den wichtigsten Handlungsfeldern. Obwohl traditionelle Grundnahrungsmittel wie zum Beispiel verschiedene Hirsearten hierbei einen wichtigen Beitrag leisten können, haben Forscher und politische Entscheidungsträger diesen Feldfrüchten in den vergangenen Jahrzehnten kaum Beachtung geschenkt.

In der vorliegenden Dissertation werden die Potentiale und Hemmnisse in der Produktion und Vermarktung des traditionellen Getreides Fingerhirse in Westkenia untersucht. Fingerhirse (Eleusine coracana) war bis zu Beginn der Kolonialzeit eines der wichtigsten Grundnahrungsmittel in der Region, wurde jedoch im Laufe des letzten Jahrhunderts fast vollständig durch Mais ersetzt. Obwohl Mais ein höheres Ertragspotential besitzt und einen geringeren Arbeitsaufwand erfordert, wurden die Grenzen einer maisbasierten Produktions- und Ernährungweise in den letzten Jahrzehnten sichtbar: Bodenerosion und zunehmend unberechenbare Regenzeiten führten zu stagnierenden oder sinkenden Maiserträgen, zudem lässt sich ein weit verbreiteter Mangel an Mikronährstoffen beobachten, der auf eine einseitige, maisbasierte Ernährung zurückzuführen ist. Fingerhirse ist nicht nur nahrhafter als Mais, sondern auch besser an nährstoffarme Böden und Trockenheit angepasst. Weiterhin waren die Marktpreise für Fingerhirse in den vergangenen Jahren deutlich höher als die Marktpreise für Mais.

Die in der vorliegenden Dissertation analysierten Daten wurden 2012 in einer Haushaltsbefragung von 270 Fingerhirseproduzenten in Westkenia erhoben. Im ersten Teil der empirischen Analyse wurde der Einfluss unterschiedlicher Faktoren auf die Anwendung von verbesserten landwirtschaftlichen Produktionsmethoden im Hirse- und Maisanbau untersucht. Hierzu zählt auch die Wirkung von verbesserten Produktionsmethoden auf die Erträge im Hirseanbau. Der zweite Teil der Dissertation widmet sich derjenigen Faktoren, die den Verkauf und die Verkaufspreise von Hirse beeinflussen. Im dritten Teil wird schließlich die Rentabilität der Hirse- und Maisproduktion verglichen und Faktoren untersucht, die sich auf die Effizienz des Produktionsprozesses auswirken.

Verbesserte Anbaumethoden sind für eine Steigerung der landwirtschaftlichen Produktion und Produktivität unerlässlich. Hierzu wurde eine multivariable Probitanalyse durchgeführt, um die Bedeutung der Anwendung von modernen Sorten und synthetischen Düngemitteln im Hirse- und Maisanbau zu untersuchen. Die Ergebnisse zeigen, dass soziale Netzwerke einen großen Einfluss auf die Anwendung von verbesserten Praktiken im Hirseanbau haben, aber für die Anwendung von 
verbesserten Produktionsmethoden im Maisanbau von untergeordneter Bedeutung sind. Dies verdeutlicht, dass Informationen und modernes Saatgut im Fall von Hirse schwerer zugänglich sind und soziale Netzwerde sowie der Zugang zu landwirtschaftlicher Beratung und modernen Kommunikationsmethoden somit eine größere Rolle spielen. Anhand einer Cobb-Douglas Produktionsfunktion kann gezeigt werden, dass die Anwendung von modernem Saatgut und synthetischen Düngemitteln einen signifikanten und positiven Einfluss auf die Hirseerträge hat.

Neben Ertragssteigerungen ist für Kleinbauern die Steigerung der Einkommen ein wichtiger Weg aus der Armut. Aufgrund hoher Transaktionskosten sind viele Kleinbauern jedoch von landwirtschaftlichen Märkten ausgeschlossen, insbesondere von besonders profitablen Märkten wie der Exportlandwirtschaft. Für Frauen sind die Markteintrittsbarrieren häufig besonders hoch. Die Vermarktung von traditionellen Getreidearten kann daher für die Landwirte, die von anderen Märkten ausgeschlossen sind, eine attraktive Einkommensalternative darstellen. Anhand eines Probit-Modells kann gezeigt werden, dass die Markteintrittsbarrieren für den Verkauf von Hirse gering sind und weder arme Haushalte noch Frauen vom Markt ausgeschlossen sind. Die Verkaufspreise schwanken jedoch stark. Weiterhin legen die Ergebnisse einer linearen Regression der Verkaufspreise nahe, dass Frauen im Durchschnitt niedrigere Preise erzielen als Männer, sofern sie nicht in Gruppen organisiert sind.

Der Vergleich der Rentabilität des Hirseanbaus und des Maisanbaus zeigt, dass sich die Deckungsbeiträge pro Hektar nicht stark unterscheiden, sofern Opportunitätskosten für Familienarbeit nicht berücksichtigt werden. Bei einer Berücksichtigung der Opportunitätskosten sind die Deckungsbeiträge in der Maisproduktion mehr als doppelt so hoch wie die Deckungsbeiträge in der Hirseproduktion. Mit einer stochastischen Grenzfunktion wurden daher die Effizienzen in der Hirse- und Maisproduktion ermittelt und Faktoren untersucht, die einen Einfluss auf die Effizienz haben. Bei beiden Feldfrüchten ist die durchschnittliche Effizienz deutlich geringer als die Effizienz der besten angewandten Technologie. Die Diskrepanz zwischen der durchschnittlichen und der höchsten Effizienz ist jedoch im Hirseanbau stärker. Die Effizienzgleichung im Hirsemodell zeigt, dass Gruppenzugehörigkeit eine effizienzsteigernde Wirkung hat, während Frauen im Schnitt ineffizienter produzieren.

Zusammenfassend kann gesagt werden, dass eine Mischung aus technischen und institutionellen Veränderungen notwendig ist, um Hirse für die Landwirte attraktiver zu machen. In Bezug auf technische Veränderungen sind vor allem eine Steigerung des Ertrags sowie eine Verringerung des Arbeitsbedarfs erforderlich. Institutionelle Veränderungen beinhalten die Förderung von Produzentengruppen, die insbesondere für Frauen sowie im Anbau von traditionellen Grundnahrungsmitteln große Bedeutung besitzen. 


\section{Acknowledgements}

The help and support of many people in Kenya and Germany made this dissertation possible. First, I am grateful to my supervisor Prof. Dr. Meike Wollni for encouraging me to pursue a Ph.D. and for always giving me valuable feedback when I needed it. A number of other people from the Department of Agricultural Economics and Rural Development at the University of Göttingen deserve my gratitude; Prof. Dr. Matin Qaim for co-supervising my dissertation, Prof. Dr. Achim Spiller for serving on the examination committee, and my colleagues and fellow doctoral students for their moral and professional support.

In Kenya I received important support from the International Crops Research Institute for the SemiArid Tropics (ICRISAT) in Nairobi as well as the Kenyan Agricultural Research Institute (KARI) in Kakamega. At ICRISAT, I would like to thank Dr. Alastair Orr for his valuable help and his interest in my research topic and Dr. Christin Schipmann for her great hospitality and her survival tips. At KARI, I am indebted to Dr. Chrispus Oduori for providing me with crucial information on the KARI extension activities. I am furthermore indebted to Richard Shikuku from Kote Mtaani Health and Environment Concerns (KOMHEC), who helped me to contact the village groups and to better understand the research setting. I would also like to thank Catherine Kinyanjui, Hope Wandera, and Laura Ouma for being very skilled and reliable enumerators. I am furthermore deeply thankful to the farmers who patiently answered all my questions and revealed a lot of personal information to complete strangers. Finally, my time in Kenya would not have been such an unforgettable and great experience without all the inspiring and amazing people that I met in Nairobi, in Kisumu, and in the villages of Western Province.

A large part of my doctoral studies was funded by the Dorothea Schlözer Scholarship Program at Göttingen University. Funding for the field work was provided by the Courant Research Centre "Poverty, Equity and Growth in Developing Countries" at Göttingen University, which is funded by the German Research Foundation (DFG).

Last but not least, I would like to thank my friends and family for being a part of my life. I am particularly thankful to my parents for their unconditional love and support. 


\section{Table of contents}

SUMMARY . .1

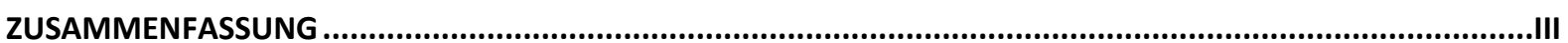

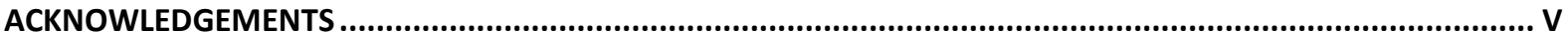

TABLE OF CONTENTS.................................................................................................................................. VII

LIST OF TABLES

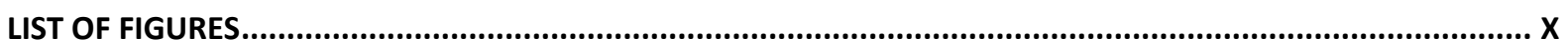

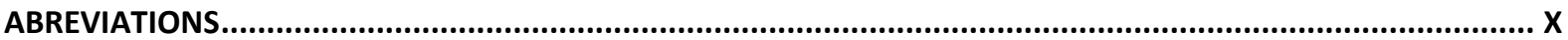

1 GENERAL INTRODUCTION................................................................................................................

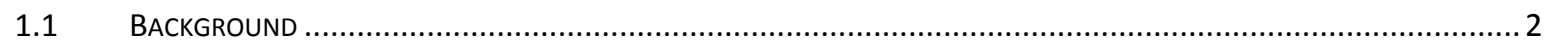

1.1.1 Global challenges for the agricultural sector ..........................................................................

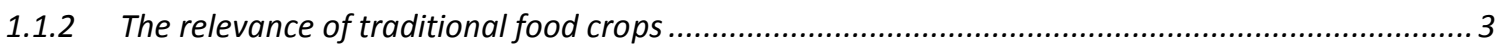

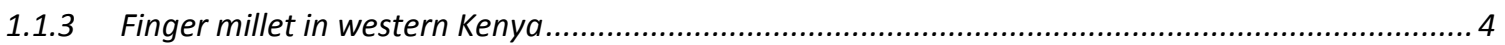

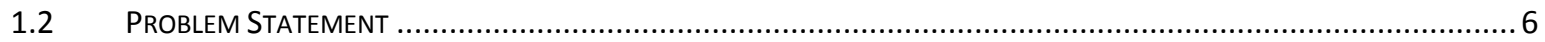

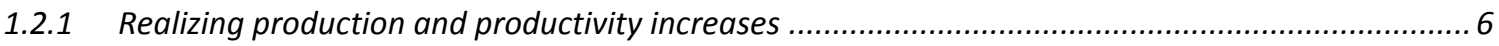

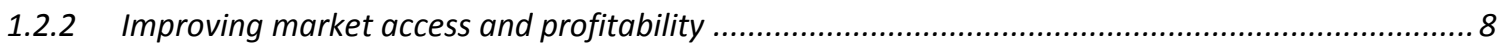

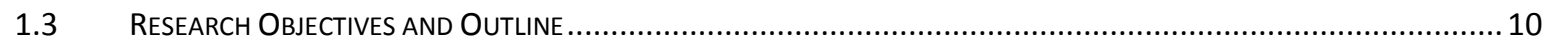

2 IMPROVED PRODUCTION SYSTEMS FOR TRADITIONAL FOOD CROPS: THE CASE OF FINGER MILLET IN

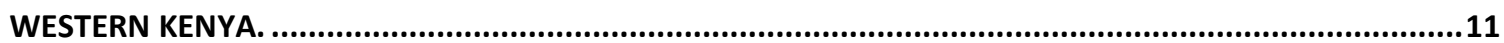

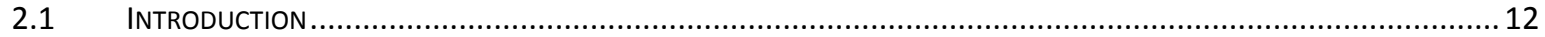

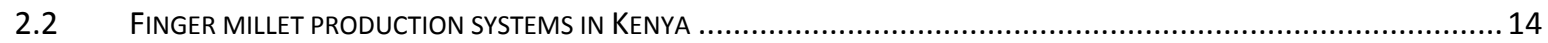

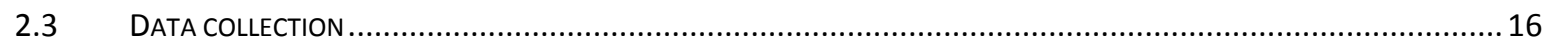

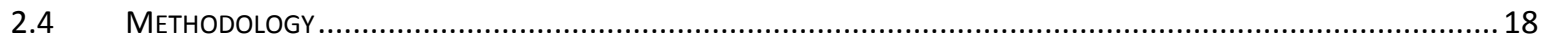

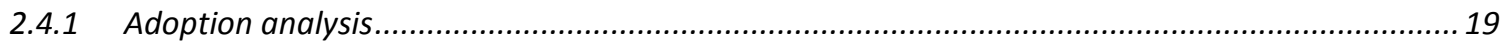

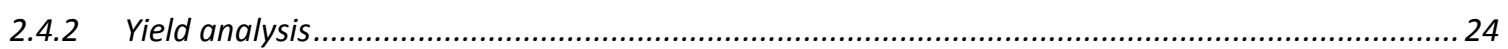

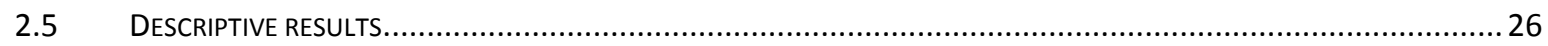

2.5.1 Adoption of improved cropping practices ................................................................................. 26

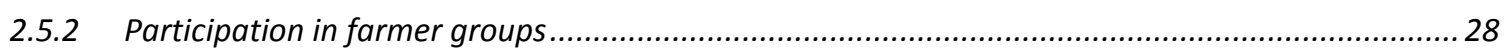

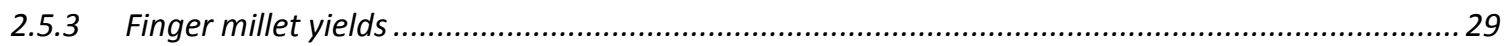


2.5.4 Results on the adoption of improved practices................................................................ 30

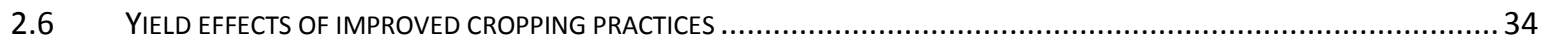

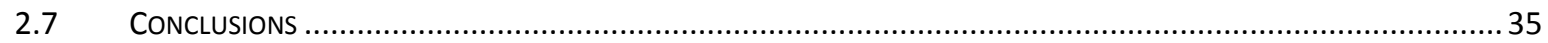

3 TRADITIONAL FOOD CROP MARKETING IN SUB-SAHARAN AFRICA: DOES GENDER MATTER? ...............39

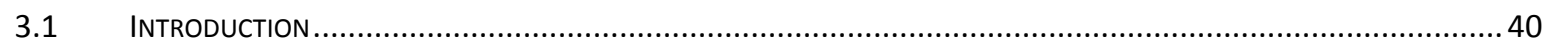

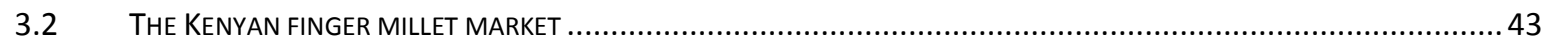

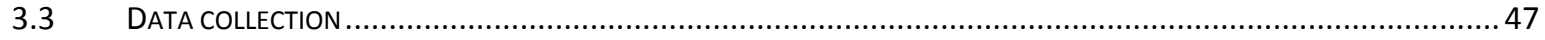

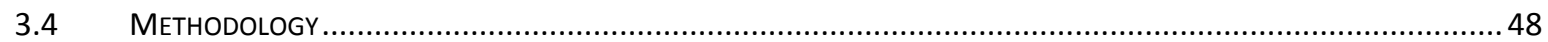

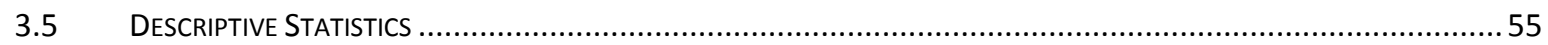

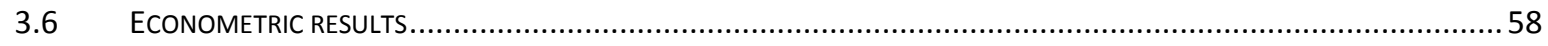

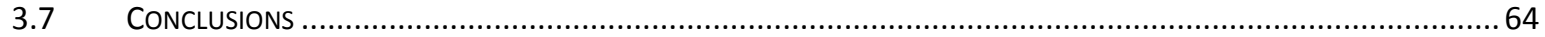

4 TECHNICAL EFFICIENCY AND PROFITABILITY OF TRADITIONAL FOOD CROP PRODUCTION IN SUB-

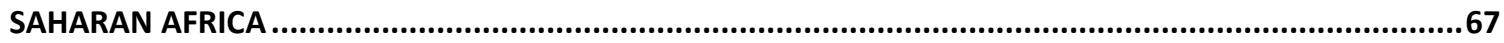

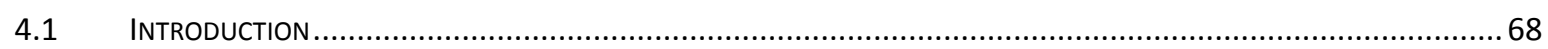

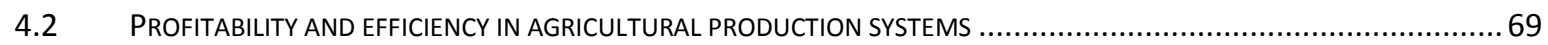

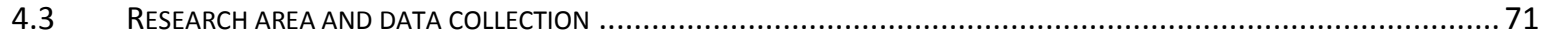

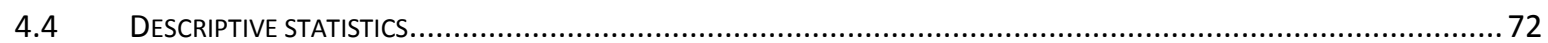

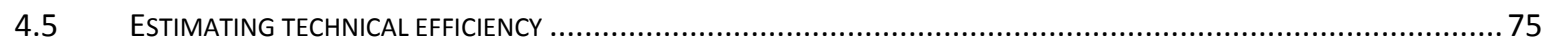

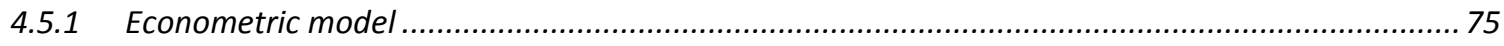

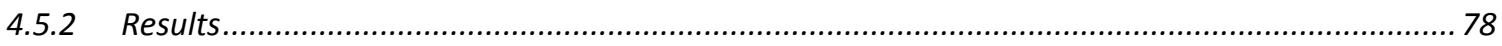

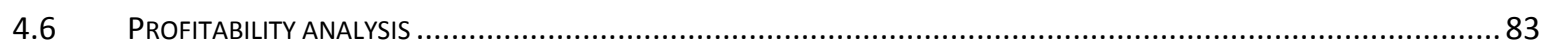

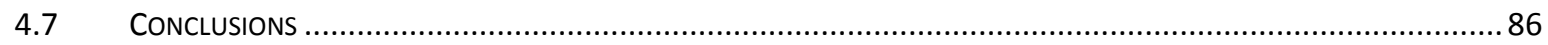

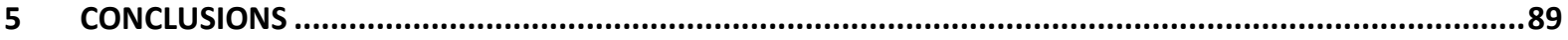

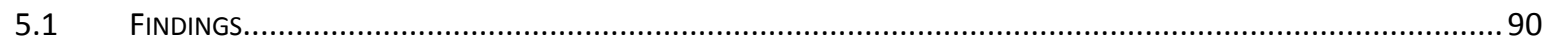

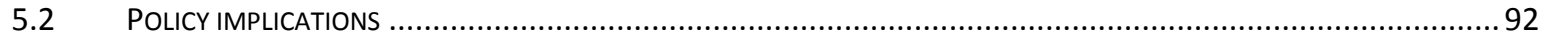

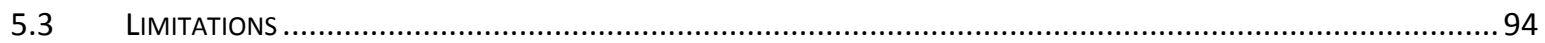

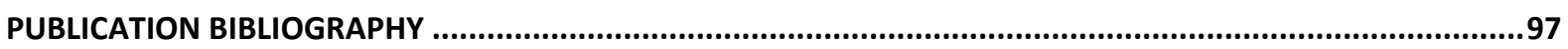

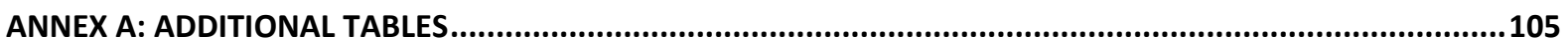

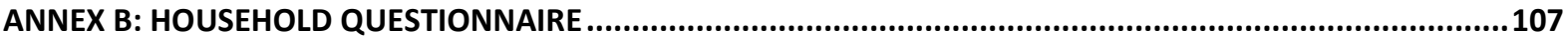




\section{List of Tables}

Table 2.1: Explanatory variables for the adoption of improved finger millet practices

Table 2.2: Variables used in the Cobb-Douglas production function .25

Table 2.3: Relationship between maize and finger millet cropping practices..... .28

Table 2.4: Average yields per acre .29

Table 2.5: Main yield constraints in finger millet production (farmers' perception) 30

Table 2.6: Regression results on the adoption of improved finger millet practices. 31

Table 2.7: Regression results on the adoption of improved maize cropping practices.

Table 2.8: Model statistics of the adoption analysis 34

Table 2.9: Cobb-Douglas production function. 35

Table 3.1: Variables used in regression models. 54

Table 3.2: Participation in village groups 57

Table 3.3: Selling prices. 58

Table 3.4: Market participation .60

Table 3.5: Selling prices. .63

Table 4.1: Composition of female and male farm incomes .73

Table 4.2: Input and yield differences between male and female producers .74

Table 4.3: Efficiency model results .79

Table 4.4: Technical efficiency estimates .80

Table 4.5: Input costs per acre. .84

Table 4.6: Yields and profits .85

Table 4.7: Advantages and disadvantages of finger millet in comparison to maize .86

Table A 1: First stage results of the FIML Heckman selection model. 105

Table A 2: Variables used in efficiency model 106 


\section{List of Figures}

Figure 3.1: Kenyan grain market prices in 2011

Figure 4.1: Finger millet production

Figure 4.2: Female finger millet producers.

Figure 4.3: Male finger millet producers

Figure 4.4: Maize production

Figure 4.5: Female maize producers .82

Figure 4.6: Male maize producers .82

\section{Abreviations}

$\begin{array}{ll}\text { CIMMYT } & \text { International Maize and Wheat Improvement Center } \\ \text { FAO } & \text { Food and Agriculture Organization } \\ \text { ICRISAT } & \text { Full Information Maximum Likelihood } \\ \text { IFAD } & \text { International Crops Research Institute for the Semi-Arid Tropics } \\ \text { KACE } & \text { Kenyan Agricultural Commodity Exchange } \\ \text { KARI } & \text { Kenyan Agricultural Research Institute } \\ \text { KES } & \text { Kenyan Shilling } \\ \text { OLS } & \text { Ordinary Least Squares } \\ \text { PMG } & \text { Producer Marketing Group } \\ \text { TISA } & \text { The Institute for Social Accountability } \\ \text { UNDP } & \text { United Nations Development Programme }\end{array}$




\section{Part one}

1 General introduction 


\subsection{Background}

\subsubsection{Global challenges for the agricultural sector}

Despite remarkable successes in reducing extreme poverty and hunger over the past years, around 0.9 billion people are still chronically undernourished and 1.2 billion people live in extreme poverty today (UNDP 2013). The agricultural sector worldwide is confronted with unprecedented challenges and needs to provide for both, food and income opportunities for the poor.

In terms of food production, the prospects of bringing new land under cultivation are limited, while existing agricultural land is increasingly subject to climate change, soil depletion, and water scarcity. At the same time, the demand for agricultural products is rapidly increasing due to mega-trends such as population growth, changing eating habits towards more meat and dairy products, and an increasing production of biofuels (Godfray et al. 2010; IFAD 2010). According to the International Fund for Agricultural Development (IFAD), global food production will have to increase by $70 \%$ until 2050 in order to achieve global food security (IFAD 2010). Since small farms occupy a large share of the worldwide agricultural land (IAASTD 2009), such an increase in worldwide food production can only be achieved if small-scale farmers in developing countries are able to increase their production. Two crucial ways to achieve this production increases are (a) the adoption of improved technologies and (b) an efficient use of the available inputs and technologies.

In terms of poverty reduction, as much as $76 \%$ of the world's poor live in rural areas, a large majority of them being small-scale farmers or agricultural wage laborers (Dercon 2009). Subsequently, agriculture plays a larger role in poverty reduction than other economic sectors in developing countries (Thirtle et al. 2003; Christiaensen \& Demery 2007). Improving market access for smallscale farmers in developing countries is therefore seen as a key to overcome poverty (von Braun 1995; Barrett 2008; Maertens \& Swinnen 2009; Rao \& Qaim 2011). To implement policies that successfully increase farm incomes, the marketing constraints and the income potential of different crops and cropping systems have to be assessed. 
While much research has been done to better understand the challenges of achieving production and productivity increases as well as better market access for small-scale farmers in developing countries, little attention has been given to traditional food crops such as millets. This dissertation adds to the existing literature by assessing major issues concerning production and income opportunities in the case of a traditional food crop - finger millet - in western Kenya.

\subsubsection{The relevance of traditional food crops}

The production and consumption of traditional food crops in developing countries has continuously declined over the past decades. Indigenous cereals like millets, sorghum or tef have been replaced by main food grains, namely maize, wheat, and rice (Kennedy \& Reardon 1994; National Research Council 1996; Boughton \& Reardon 1997). This decline of traditional food crop production and consumption has been accompanied by an extensive neglect of traditional food crops by researchers and policy makers.

Main food grains allow for high yields and high input productivity and therefore play an important role to achieve global food security. On the other hand, the global dominance of a few main food grains has led to a range of problems in terms of food security. First and foremost, a lack of agrobiodiversity makes agricultural systems less resilient towards disease outbreaks and poor agroecological conditions (Frison et al. 2011). The rapid spread of the wheat rust fungus strain Ug99 across the globe demonstrated how easily global food production can be imperiled by just one pathogen (Ayliffe et al. 2008). In terms of agro-ecological conditions, climate change and an overuse of agricultural resources are leading to depleted soils and erratic water supply in many regions of the world (Godfray et al. 2010). Many traditional food crops are better adapted to poor soils, heat, and droughts than main food grains (Pearce 1990; National Research Council 1996).

Another problem related to the dominance of a few main staple foods is the high prevalence of micronutrient deficiencies in many developing countries. For example, it is estimated that over 2 billion people worldwide suffer from iron deficiency (Welch \& Graham 1999). The diets of the poor 
in developing countries are predominantly based on starchy staple crops, with little consumption of animal products or fresh fruits and vegetables. A diversification of diets is important to prevent micronutrient deficiencies and the related health problems such as anemia. Since the budget constraints of poor people turn meat and dairy products into luxury goods, such a diversification has to take place not only across food groups, but also within food groups (Welch \& Graham 1999; Ruel 2003). A study by Frison et al. (2006) points out the importance that traditional crops play in the provision of micronutrients. Besides a range of traditional vegetables, traditional cereals such as millets and tef contain high amounts of iron and other essential micronutrients (National Research Council 1996).

\subsubsection{Finger millet in western Kenya}

Finger millet (Eleusine coracana) originates in the highlands of Uganda and Ethiopia and is nowadays mainly grown in eastern and southern Africa as well as in India. Although it is a main staple crop for millions of people worldwide, it is widely neglected by policy makers and researchers. Since a couple of decades, this neglect by researchers and policy makers has been accompanied by a rapidly dwindling production area in many regions, including western Kenya (National Research Council 1996).

Finger millet and sorghum used to be the most important cereals in western Kenya in the precolonial era. Since the beginning of the 1930 s, the area dedicated to maize increased rapidly and maize production soon surpassed finger millet production (Crowley \& Carter 2000). Today, maize is by far the most important staple crop in western Kenya, while finger millet is only grown by a minority of farmers. Countrywide, millets ${ }^{1}$ were grown on 0.1 million hectares in 2012 with an average yield of 0.6 tons per hectare. In contrast, maize was grown on 2.2 million hectares with an average yield of 1.7 tons per hectare in 2012 (FAO 2013). Besides the poor reputation of finger millet as being a famine food or bird seed, tangible weaknesses of finger millet contributed to the crop's

\footnotetext{
${ }^{1}$ The FAO is not differentiating between different types of millet.
} 
decline in the region. Most importantly, finger millet does not have the same yield potential as maize, not least due to the wide neglect of the crop by breeders and seed companies. However, finger millet holds a range of advantageous properties and the limits of a maize based production system have become apparent over the past decades.

Although western Kenya is a high potential area with enough rainfall and two cropping seasons, agricultural yields are stagnating or declining for many farmers (Crowley \& Carter 2000). High population pressure has provoked unsustainable cropping practices on very small farms and plots. Fallow periods, crop rotation and the incorporation of crop residues or other organic materials were reduced in the past. This development led to a dramatic decrease in soil fertility and stagnating or declining maize yields over the years (Crowley \& Carter 2000). In addition, climate change is causing more unpredictable weather conditions in the region. While maize is growing well in favorable agroecological conditions, finger millet is better adapted to poor soils, high temperatures, and erratic rainfall and can therefore play an important role for improving food security in the region (Gill \& Turton 2001). The good storability of finger millet is a further advantage, especially against the background that grain post-harvest losses constitute up to $40 \%$ of the grain yields in Kenya (CIMMYT 2013). In contrast to maize, finger millet can be stored for several years and hence improves food security for small-scale farmers who face persistent risks of crop failure and poor market access (Oduori 2005).

The declining agro-biodiversity in western Kenya has been accompanied by a decline in dietary diversity, with maize being by far the most consumed food. Subsequently, micronutrient deficiencies and deficiencies in essential proteins are widespread in the region (Conelly \& Chaiken 2000). Compared to maize, finger millet is rich in important micronutrients like iron and vitamin $A$ and contains high amounts of essential proteins such as methionine (National Research Council 1996). Its high calcium content makes finger millet a valuable food for pregnant and nursing women as well as for small children. The crop is furthermore seen as particularly valuable for HIV patients and diabetics (Mitaru \& Githiri 2007). 
Last but not least, finger millet has the potential to make an important contribution to farm incomes in the region. As opposed to typical cash crops like cotton or sugarcane, food crops can be marketed within the village or on local markets. This makes food crops an important income option, especially for those farmers who do not access high value cash crop markets. While the production of finger millet has been declining, there is still a significant demand for the crop and finger millet prices in Kenya have been far above maize prices or any other cereal prices over the past years (Oduori 2005).

\subsection{Problem Statement}

Although the above mentioned advantages of finger millet over maize have been identified by researchers in the past, little efforts have been made to rigorously assess the potential and the constraints in the production and marketing of finger millet or other traditional food crops. This dissertation assesses several aspects of finger millet production and marketing, including the adoption of improved finger millet practices, the marketing and selling prices, the profitability of the crop, and the technical efficiency in the production of finger millet. Since finger millet has been mainly replaced by maize in the research area, maize is used as the benchmark crop for comparisons in most of the analyses. A review of existing research and research gaps is given before specific research questions are formulated.

\subsubsection{Realizing production and productivity increases}

Western Kenya belongs to the most densely populated regions in Sub-Saharan Africa, were a growing rural population has to make a living from increasingly scarce land resources. Improved cropping practices are necessary to boost yields and avoid further land degradation. In addition, the technical efficiency with which the inputs are used has to be improved (Crowley \& Carter 2000). If policy makers want traditional food crops like finger millet to play a role in the future of the Kenyan farming sector, an adoption of improved cropping practices and an increase in technical efficiency need to be realized in the production of these crops as well. 
Identifying the factors that influence an adoption of improved cropping practices in developing countries has been in the focus of researchers since many decades. Over time, a range of factors such as education, wealth, and farm size have emerged as variables that potentially influence the adoption of improved practices (Feder et al. 1985; Feder \& Umali 1993; Knowler \& Bradshaw 2007). More recent literature has focused on the role of social networks and social learning in the adoption process. Both, formal and informal social networks have been shown to positively affect the adoption of improved practices (Besley \& Case 1993; Foster \& Rosenzweig 1995; Langyintuo \& Mungoma 2008; Wollni et al. 2010). While there has been a lot of research on the adoption of improved cropping practices in the production of main cereals like maize (Kaliba et al. 2000; Groote et al. 2005; Feleke \& Zegeye 2006; Sauer \& Tchale 2009; Mignouna et al. 2011), very little efforts have been made to understand adoption processes in the production of traditional cereals. Only a few studies focus on the adoption of improved sorghum and pearl millet varieties (Nichola 1996; Matuschke \& Qaim 2008; Cavatassi et al. 2011). To the best of our knowledge, there is no study that provides empirical information on the adoption of improved finger millet practices. Although many factors influence the adoption of improved practices similarly across different crop types, there are presumably significant differences between the adoption processes for main staple crops and marginalized traditional food crops. For example, social networks can play a more important role when formal sources of information and inputs are scarce (Wu \& Pretty 2004; Matuschke \& Qaim 2009; Conley \& Udry 2010).

Besides the adoption of improved cropping practices like the use of modern inputs, a technically efficient use of these inputs is essential to obtain high yields. The emergence of literature dealing with technical efficiency in the context of small-scale farmers in developing countries started in the 1960s, when Schultz (1964) formulated his "poor but efficient" hypothesis. There is now an extensive strand of empirical literature that assesses the technical efficiency in the farming sector. Many studies find low levels of technical efficiency (Kaliba 2004; Tchakounte et al. 2012) with a high variability of efficiency estimates across farms (Goyal et al. 2006; Backman et al. 2011). These 
findings underline that an assessment of the factors influencing technical efficiency is important. Existing literature has identified factors such as market access, group membership, and education to have an influence on technical efficiency (Phillips \& Marble 1986; Bravo-Ureta \& Pinheiro 1997; Binam et al. 2003; 2004; Rao et al. 2012; Wollni \& Brümmer 2012). However, very few studies assess technical efficiency with a specific focus on traditional food crops. Whether or not gender has a significant influence on technical efficiency remains inconclusive in the scientific debate. A literature review by Quisumbing (1996) concludes that most studies do not find a significant influence of gender on technical efficiency, On the other side, Quisumbing (1996) also underlines that most efficiency studies suffer from methodological shortcomings in their gender analysis. Against the background that female farmers often face particular constraints in their access to productive resources, more empirical results on the effect of gender on technical efficiency would help to design policies that assist female farmers to improve their production systems. This is of particular importance in the case of traditional food crops, which are often considered as "female crops" (Doss 2002).

\subsubsection{Improving market access and profitability}

Small-scale farmers often face high barriers to enter agricultural markets due to a deficient rural infrastructure and other factors that increase transaction costs (Key et al. 2000; Barrett 2008; Shiferaw et al. 2008). Market barriers are particularly high in the case of high-value agricultural markets like export vegetables due to high quality and standard requirements (Reardon et al. 2009). The sales of food crop surpluses therefore constitute an important source of income for small-scale farmers in developing countries, especially for the smallest and least endowed farmers who do not access high-value agricultural markets or other sources of income. The income derived from food crops can also be of particular importance for female farmers, since women often face higher barriers to access high-value agricultural markets than men (Zeller et al. 1998). 
A number of studies have been conducted to assess the factors that help small-scale farmers to overcome market barriers and obtain higher selling prices are assessed. It has been shown that producer marketing groups (PMGs) or other forms of collective action can decrease transaction costs, increase the farmers' bargaining power, and improve the farmers' access to services and information (Roy \& Thorat 2008; Kaganzi et al. 2009; Narrod et al. 2009; Fischer \& Qaim 2012b; Wollni et al. 2010). However, farmer collective action is not necessarily leading to improved market access and the success of farmer collective action depends on a range of group and product characteristics (Markelova et al. 2009). It remains furthermore unclear in how far farmer collective action improves the situation of female farmers. Collective action is often seen as a way to overcome the particular disadvantages that female farmers face. However, recent research suggests that women are often marginalized in male dominated farmer groups and lose control over their crops (Fischer \& Qaim 2012a). At the same time, women groups have been shown to be disadvantaged in terms of market access and marketing prices when compared to male dominated farmer groups (Barham \& Chitemi 2009). Despite the large amount of literature dealing with smallholder market access, empirical evidence on the marketing of traditional food crops remains scarce. Against the background that the income derived from traditional food crop marketing is of particular importance for the most disadvantaged farmers, marketing constraints and determinants of selling prices for traditional food crops have to be better understood.

Ultimately, the aspects of traditional food production and marketing that are assessed in the present dissertation are decisive for the profitability of traditional food crops. The crops' economic potential in comparison to the economic potential of main staple crops is of crucial importance for the farmers' cropping decisions. Small-scale farmers encounter various challenges to achieve profitability. Especially female farmers are often hampered in obtaining profitability due to a constrained access to in- and output markets as well as farm productive resources such as high quality land (Zeller et al. 1998; Quisumbing \& Pandolfelli 2010; Croppenstedt et al. 2013; Kilic et al. 2013). Although there are studies that compare the profitability of cash crops and traditional 
cropping systems (Rourke 1974; Boateng et al. 1987; Lukanu et al. 2009), we are not aware of any study that is comparing the profitability of main cereals and traditional cereals.

\subsection{Research Objectives and Outline}

As outlined in the previous chapter, this dissertation focuses on improved technologies, technical efficiency, and income opportunities in the production of finger millet in western Kenya. Goal of the dissertation is to assess the potential and constraints in the cultivation and marketing of finger millet. Since finger millet has been widely replaced by maize over the past century and maize is nowadays grown by almost every farmer in the country, most parts of the empirical analysis will provide a comparison between finger millet and maize. A main focus of this dissertation lies on two cross-cutting issues: The role of gender and the role of collective. The specific research questions are as follows:

1. Which factors influence the adoption of improved finger millet and maize technologies?

2. What is the effect of improved cropping practices on finger millet yields?

3. In how far are the decision to market finger millet and the selling prices influenced by factors on the household level?

4. Which factors influence the technical efficiency in finger millet and maize production?

5. What are the per-acre profits obtained from finger millet and maize production?

Research questions one and two are assessed in part two of this dissertation. Part three is assessing research question three. Research questions four and five are assessed in part four. Conclusions, policy implications, and limitations of this dissertation are given in part five. The empirical analysis is based on survey data from 270 households located in three different districts of Western Province in Kenya. The survey contains information of production and marketing practices as well as on a range of household and farm characteristics. The data collection took place in early 2013 in collaboration with ICRISAT Nairobi. A more detailed description of the data collection approach is given in parts two to four of this dissertation. We employ descriptive and econometric analyses in order to provide answers to the above mentioned research questions. 


\section{Part two}

\section{Improved production systems for traditional food crops:} The case of finger millet in western Kenya. ${ }^{2}$

Increasing agricultural productivity through the dissemination of improved cropping practices remains one of the biggest challenges of this century. A considerable amount of literature is dedicated to the adoption of improved cropping practices among smallholder farmers in developing countries. While most studies focus on cash crops or main staple crops, traditional food grains like finger millet have received little attention in the past decades. The present study aims to assess the factors that are influencing adoption decisions among finger millet farmers in western Kenya. Based on cross-sectional household data from 270 farmers, we estimate a multivariate probit model to compare the adoption decisions in finger millet and maize production. While improved practices such as the use of a modern variety or chemical fertilizer are well known in maize production, they are less common in finger millet production. Results show that social networks as well as access to extension services play a crucial role in the adoption of improved finger millet practices, while the same variables are of minor importance for the adoption of improved maize practices. A CobbDouglas production function shows a positive effect of modern varieties and chemical fertilizer on finger millet yields.

\footnotetext{
${ }^{2}$ Submitted to Applied Economic Perspectives and Policy in June 2013
} 


\subsection{Introduction}

In the second half of the $20^{\text {th }}$ century, the agricultural sector worldwide was characterized by remarkable increases in production and productivity. Nevertheless, about one billion people are undernourished today and due to population growth, degrading natural resources, and climate change, a sustainable and substantial growth in agricultural production remains one of the most urgent challenges in the beginning of the $21^{\text {st }}$ century (Godfray et al. 2010; IFAD 2010). Besides the development of new technologies, e.g. new varieties or management practices, closing the gap between actual productivity and the potential productivity that could be obtained by using and adapting currently available technologies is crucial to facing this challenge (Godfray et al. 2010).

This yield gap is especially high in small-scale production systems in developing countries, where farmers do not have enough information or capacities to adopt innovative technologies. Much effort has been made to tackle this problem and a considerable amount of literature is analyzing the adoption decisions of small-scale farmers in developing countries (Feder et al. 1985; Feder \& Umali 1993; Knowler \& Bradshaw 2007). However, while a number of studies assess the adoption of improved technologies in maize production systems in Sub-Saharan Africa (Kaliba et al. 2000; Doss \& Morris 2000; Groote et al. 2005; Sserunkuuma 2005; Feleke \& Zegeye 2006; Langyintuo \& Mungoma 2008; Sauer \& Tchale 2009; Simtowe et al. 2009; Mignouna et al. 2011), very little attention has been given to the adoption of modern production systems in traditional food crop production. Although many factors influence the adoption of improved cropping practices similarly across different crops, there are likely to be notable differences between a common cash crop (like maize) and a traditional food crop (like finger millet).

Various studies acknowledge that participation in formal social networks like farmer groups can foster learning processes and the adoption of improved cropping systems (Besley \& Case 1993; Wollni et al. 2010). Other studies stress the role of informal social networks and neighborhood effects, showing that farmers with experienced and innovative neighbors are more likely to adopt an 
innovation themselves (Conley \& Udry 2010; Foster \& Rosenzweig 1995; Langyintuo \& Mungoma 2008; Matuschke \& Qaim 2009). The role of social networks becomes especially important where other assets and formal sources of information are scarce (Wu \& Pretty 2004; Matuschke \& Qaim 2009), which is likely the case for traditional subsistence crops. In their study on technology adoption in pineapple production systems, Conley and Udry (2010) point out that social networks are of particular importance for technology diffusion and adoption in the context of a newly introduced crop, for which formal information sources are not yet available. Similarly, improved practices have not been widely used in finger millet production systems and thus experience, information, and extension is scarce in western Kenya. We therefore expect social capital, and in particular social networks, to play a crucial role in the dissemination of modern finger millet production practices.

Finger millet has been widely neglected by both researchers and policy makers in the past decades. Yet, traditional cereals like finger millet could make an important contribution towards higher farm incomes and improved food security in many regions of the world. Finger millet is known to be more nutritious and more resilient to poor or unpredictable agro-ecological conditions than main cereals like maize. The dissemination of modern technologies in finger millet production is still low, but field trials indicate that yields can be substantially increased by using modern practices and varieties (Oduori 2005). In this article, we analyze the factors that determine the adoption of improved finger millet cropping practices among smallholder farmers in western Kenya. In addition, we assess the impact of improved finger millet practices on finger millet yields. While a few studies have focused on the adoption of modern sorghum and pearl millet varieties (Nichola 1996; Matuschke \& Qaim 2008; Cavatassi et al. 2011), to the best of our knowledge there is no empirical evidence on the dissemination of modern production systems in finger millet production.

The remainder of the article is structured as follows. In the next section, we discuss the current finger millet production systems in Kenya. Afterwards, we introduce the data collection approach. Section four describes our methodological approach, and sections five to seven present the 
descriptive and econometric results of our adoption and yield analysis. Finally, section eight draws conclusions and outlines policy recommendations for the promotion of traditional cereals.

\subsection{Finger millet production systems in Kenya}

Finger millet (Eleusine coracana) originates in East Africa and is an important food crop for millions in Sub-Saharan Africa and India. Despite its importance, it has received very little attention by researchers and policy makers in the past decades. In western Kenya, finger millet used to be among the most important food crops but was largely replaced by maize over the $20^{\text {th }}$ century. Today the crop is only grown by a minority of farmers and suffers from the poor reputation of being a 'poor person's crop' or a 'birdseed' (National Research Council 1996; Crowley \& Carter 2000). This development ignores the high potential of finger millet in terms of its agronomic properties, its nutritional value, and its marketing opportunities.

Regarding its agronomic properties, finger millet can have advantages over main staple crops, especially in less-favored areas. While maize is growing well under favorable agro-ecological conditions, millets are much better adapted to poor soils, high temperatures, and erratic rainfall and can therefore play an important role in improving food security despite their lower yield potential (Gill \& Turton 2001). This holds especially true against the background of climate change and increasingly degraded soils in many African regions (Crowley \& Carter 2000). A further advantage of finger millet is its good storability, which is of particular importance for the food security of smallscale farmers, who face persistent risks of drought and crop failure (Oduori 2005).

Furthermore, finger millet also represents a promising opportunity to improve nutrient availability to poor households. As in many parts of Sub-Saharan Africa, dietary diversity in western Kenya is low, with maize being the dominant staple crop. Consequently, deficiencies in various proteins and micronutrients are very common (Conelly \& Chaiken 2000). While the level of food energy is roughly the same for finger millet and maize, finger millet is richer in essential proteins, especially methionine, and important micronutrients such as calcium and iron. Some nutritionists claim that 
finger millet represents the key crop against micronutrient deficiencies in Sub-Saharan Africa (National Research Council 1996).

Finally, there are good marketing opportunities for finger millet, especially in local, easily accessible markets. While finger millet is mainly considered a staple crop that farmers grow for subsistence purposes, demand for finger millet is high and finger millet prices in Kenya are far higher than prices for maize or other cereals. Finger millet can also be processed into value added products like cookies or beer by the farmers themselves, or by processors at the local or national levels (Oduori 2005). The crop therefore has the potential to serve as a profitable cash crop for small-scale farmers in western Kenya.

Yet, the potential of finger millet production remains largely untapped. In Kenya, millets ${ }^{3}$ were grown on 0.1 million hectares in 2012 with an average yield of 0.6 tons/hectare. In contrast, maize was grown on 2.2 million hectares with an average yield of 1.7 tons/hectare in 2010 (FAO 2013). The average finger millet yield of 0.6 tons/hectare discloses a big yield gap: In finger millet yield trials, yields of up to 3.8 tons/hectare have been observed (Oduori 2005). Little effort has been made to improve the genetic material of finger millet, and while the first modern maize varieties were already available in the early 1960ies, the first improved finger millet varieties were released in the early 1990s (Byerlee \& Eicher 1997; Oduori 2005). The lack of research and development on finger millet is also reflected in most local extension approaches in developing countries. In Kenya, for example, extension programs generally do not provide specific information on finger millet production, but rather focus on maize production systems. Consequently, finger millet production remains very traditional and the crop's reputation is that of an old-people-crop with little agronomic potential. Farmers often cultivate finger millet on their most marginal plots without adding any organic or chemical fertilizer (Crowley \& Carter 2000).

Overall, the dissemination of modern technologies in finger millet production is low and we know little about adoption processes. Yet, a range of practices to optimize finger millet production

\footnotetext{
${ }^{3}$ The FAO is not differentiating between different types of millet.
} 
systems are available and promoted in western Kenya by specialized extension programs. First and foremost, the use of an improved finger millet variety can have several advantages including a higher yield potential, enhanced resilience to pests and erratic weather conditions, and improved nutritional value. Furthermore, even though finger millet is relatively well adapted to poor soils, fertilizer applications are recommended to provide a good nutrient supply in order to obtain high yields. For a more efficient use of fertilizer, a micro-dosing technique can be applied, where the fertilizer is strewed along the rows instead of being broadcasted (information received from KARI ${ }^{4}$ ). Row-planting is recommended over broadcasting, because it facilitates crop management in terms of weeding, thinning, application of fertilizer, and harvesting. Planting should be done as early as possible, since timely planting protects the crop against insect pests and weeds. Finally, weeding should ideally be done twice; a first time 14 days after germination and a second time 14 days after the first weeding. To assure enough space for the individual plants, a thinning of the rows is recommended during the first weeding (Nyende et al. 2001).

\subsection{Data collection}

Our research was carried out in Western Province, located in the southwest of Kenya. Traditionally, finger millet and sorghums were the most common cereals grown in western Kenya, but the area dedicated to maize production has been increasing rapidly since the beginning of the $20^{\text {th }}$ century (Crowley \& Carter 2000). Today, maize is by far the most important staple crop in western Kenya while finger millet is only grown by a minority of farmers. According to FAO data, about 240,000 hectares were used for maize production in Western Province in 2008 , while only 4,000 hectares were dedicated to millet production (FAO 2012). However, this figure is likely underestimating actual finger millet production, as data for a range of locations is missing or incomplete. Given its untapped potential, finger millet has received growing attention during recent years and the Kenyan

\footnotetext{
${ }^{4}$ Kenyan Agriculture Research Institute
} 
Agricultural Research Institute (KARI) implemented extension programs in Western Province to promote the adoption of improved crop management practices in finger millet production.

We conducted a household survey among 270 finger millet farmers in Western Province in 2012. In a first stage we selected three districts, namely, Teso, Busia and Butere-Mumias out of the total of eight districts located in Western Province ${ }^{5}$. These three districts represent the main area in which KARI has carried out extension programs on millet production. The districts vary with respect to agro-ecological conditions and farming systems. During the interviews with different farmer groups and experts from KARI, a general picture of Teso emerged as having the most traditional and less commercialized farming sector. Located at the border to Uganda, finger millet is still of considerable importance in people's diets and farming systems. Although cash crops such as cotton or tobacco are grown in Teso, farmers mainly cultivate food crops for their subsistence needs. Teso is partly located in mountainous areas with shallow and poor soils. In contrast, farmers in Butere-Mumias have more modern and commercialized farming systems with sugar cane being the most important cash crop and finger millet being of minor importance. Geographically and in terms of its farming systems, Busia is located in between Teso and Butere-Mumias.

In a second step of our sampling procedure, we selected 15 locations situated in Teso, Busia and Butere-Mumias. In 12 of the 15 locations, KARI had provided millet-related extension services to farmers between 2007 and 2010. The 12 locations were randomly chosen from a total of 32 locations were KARI had provided finger millet extension services. To reach the farmers, KARI used a group approach supporting social groups that were interested in finger millet activities. The extension program comprised training on finger millet farming, processing and marketing. In addition, field days with participatory variety selection were organized. To select the farmers for the interviews, we applied a stratified random selection: In each of the 12 KARI locations, we interviewed nine millet farmers who are members of a group that had received finger millet

\footnotetext{
${ }^{5}$ The administrative areas in Kenya were regularly subject to reforms that split districts into smaller units. The last district reform took place in 2007, were e.g. Teso District was split into Teso North and Teso South. For reasons of simplicity, we are referring to the number of districts and district boundaries that existed before the 2007 reform.
} 
extension from KARI and nine millet farmers who are not members. Additionally to the 12 KARI locations, we randomly chose three external locations, where no KARI intervention had taken place. In each of these control villages we interviewed 18 finger millet farmers. Lists of farmers who cultivated finger millet in 2011 were obtained from KARI group leaders (for extension group members) and from village elders (for all millet farmers in the villages). We then selected farmers randomly from the compiled lists for our survey. Our stratified sampling design is oversampling farmers who received finger millet extension through the KARI program. We take this into account by including sampling weights in the econometric analysis.

A standardized questionnaire was used to collect information on farm and household characteristics, cropping practices, and social networks. All agricultural production data is referring to the year 2011 . There are two cropping seasons in western Kenya: The long-rains (approx. from February to July) and the short-rains (approx. from October to December). Since finger millet is only grown during the long- rains, all figures and analyses presented in this article refer exclusively to the long-rains. To obtain further information on finger millet production and typical group activities in the region, we conducted additional interviews with farmer groups and finger millet experts.

\subsection{Methodology}

We model the adoption of improved yield-enhancing technologies including modern varieties and chemical fertilizer using an econometric approach. Our focus lies on the adoption of improved finger millet technologies, but we are also interested in potential differences between adoption decisions in the production of neglected food crops like finger millet and main food crops like maize. The adoption of an improved practice in finger millet production is likely related to the adoption of the same practice for more common food crops. We therefore model the adoption of improved technologies in both finger millet and maize production jointly in a multivariate probit model. To analyze the effect of improved cropping practices on finger millet yields, we estimate a CobbDouglas production function 


\subsubsection{Adoption analysis}

Farmers are expected to base their decision to adopt a practice on the expected profitability of that practice. We model the expected profitability of a practice $j$ by farmer $i$ as

$$
y_{i j}^{*}=\beta X_{i j}+\varepsilon_{i j}
$$

where $X$ is a vector of independent variables, $\beta$ is a vector of parameters to be estimated, and $\varepsilon$ is a normally distributed error term with mean zero and variance one. We are unable to observe the farmer's expected profitability, but we do observe the adoption of a practice as $y_{i j}=1$ if $y_{i j}^{*}>0$ and the non-adoption of a practice as $y_{i j}=0$ if $y_{i j}^{*}<0$.

However, the adoption decision for one practice is not independent from the adoption decision for other practices. Farmers who obtain information about one new technology are more likely to obtain information about other technologies as well. There is a fixed cost component in information search that makes gathering information about each additional practice relatively less expensive. Also, there might be synergy effects between different practices, e.g. between the use of a modern variety and the use of chemical fertilizer, when the modern variety used is more responsive to fertilizer than traditional varieties. On the other hand, farmers with limited financial resources may have to make a trade-off between the two inputs, deciding to use either one of them. Analogous to synergies and trade-offs that may occur between different practices for the same crop, we may observe synergies or trade-offs between adopting the same practice for different crops. Synergies between maize and finger millet cropping practices are possible in terms of access to inputs, access to information, and experiences made with certain practices. A farmer who buys a bag of chemical fertilizer for his maize production at the input store will have lower transaction costs to buy an additional bag of fertilizer for his millet crop. Similarly, a farmer who knows how to access improved maize seeds will face lower costs of information to access improved finger millet seeds. In addition to the potential synergy effects between maize and finger millet production, the expected profitability of an improved finger millet cropping practice may depend on the expected profitability 
of the same practice in maize production. Since decades, the use of chemical fertilizer and modern varieties are well-established practices in maize production in western Kenya. Thus, the farmers' expected profitability of using chemical fertilizer and improved varieties in maize production is based on actual experiences or observations in past production cycles. In contrast, many farmers have never tried or observed the same practices in finger millet production. Those farmers may instead rely on their experiences or observations in maize production when assessing the expected profitability of a finger millet cropping practice. Trade-offs between cropping practices in maize and finger millet production may occur when a farmer is cash constrained and thus cannot afford to buy expensive inputs for both crops.

Considering that the adoption decisions for different cropping practices are likely correlated with each other, estimating the adoption of each practice independently may lead to biased estimates. Following Marenya and Barrett (2007) we therefore model the adoption decisions using a multivariate probit regression framework, which allows the covariance between the error terms to be correlated across different practices and different crops. A positive correlation between two error terms indicates synergies between the respective practices, whereas a negative correlation indicates the existence of trade-offs.

The explanatory variables used in the adoption model are described in Table 2.1. Based on previous adoption studies (Feder \& Umali 1993; Govereh \& Jayne 2003; Matuschke \& Qaim 2009; Wollni et al. 2010), we identify four categories of variables that have a potential influence on the adoption decision of farmers: social networks and connectedness, wealth, human capital, and regional heterogeneity.

Social networks and connectedness can help to improve access to information and markets as well as to overcome input constraints. We include several variables that reflect the households' social networks and connectedness. First of all, group membership is an important factor that has been used in previous studies as an indicator for how well farmers are linked to markets and information 
(Fischer \& Qaim 2012b). We therefore include the number of social groups the household participates in as an explanatory variable in our model. There is a large variety of different types of social groups in rural Kenya, including farmer groups, self-help groups, widow groups and religious groups (Place et al. 2004). Since agriculture plays a central role in the livelihoods of Kenya's rural population, even groups who do not consider themselves farmers groups are often involved in agricultural activities. Thus, to better reflect the type of group activities that the household is engaged in, we include a dummy variable that equals one if the household participates in at least one group that is involved in input purchase activities. Lack of access to inputs is a common constraint for the adoption of new agricultural technologies (Moser \& Barrett 2003), which, however, can be overcome through joint purchases of farm inputs. Besides group membership, farmer-to-farmer relationships are an important aspect of social connectedness (Wu \& Pretty 2004). In particular, previous studies have shown that such informal information channels can play an important role when formal sources of information are limited (Conley \& Udry 2010). We measure contact intensity for millet farmers as the frequency with which they discuss their finger millet cropping practices with other farmers. This was based on a maximum of three finger millet farmers that the interviewees could name to have regular contact with. Possible responses ranged from "never discuss practices" (1) to "very often discuss practices" (5) and were summed up over the household's contacts. Since formal sources of information on finger millet cropping practices are not easily available in western Kenya, we expect that access to informal information on finger millet practices plays an important role in their adoption.

Furthermore, we include a variable on the distance to the next main market and a dummy variable that equals one if the farmer uses a cell phone. Being located in close proximity to a market center and disposing of a cell phone both are expected to increase the farmer's access to markets and market information and thus increase the likelihood of adoption of improved technologies. Similarly, access to extension is expected to improve the farmer's knowledge about improved practices and thus to positively affect adoption. We therefore include a dummy variable that captures whether 
farmers have received finger millet related extension. Furthermore, finger millet farmers who did not receive finger millet extension directly, but live in a village where KARI implemented its program are more likely to learn about new practices through observations or discussions with other farmers than farmers who live in villages without a finger millet extension program. To account for these possible spillover effects, we include a dummy variable that equals one if the household is located outside the KARI program villages.

In order to measure household wealth, we include three variables in our model, namely, total farm size, the number of cattle owned by the household, and the off-farm income earned by the household in 2011. Since wealthier households have better access to liquidity and often to credit (Croppenstedt et al. 2003) and are thus less likely to be cash constrained, we expect them to be more likely to adopt improved crop management practices. In addition, we control for various human capital related variables including the age of the household head, the gender of the person responsible for finger millet production, education, and the households' dependency ratio. These variables are used as proxies for the quality and quantity of labor endowment of the household. Finally, we include two regional dummies for Teso and Butere-Mumias to account for differences in agro-ecological conditions and farming systems in the three different districts. 
Table 2.1: Explanatory variables for the adoption of improved finger millet practices

\begin{tabular}{|c|c|c|c|}
\hline Variable name & Variable description & Mean & Std. Dev. \\
\hline \multicolumn{4}{|c|}{ Social networks and connectedness } \\
\hline Group number & Number of groups the household is participating in & 1.848 & 1.239 \\
\hline $\begin{array}{l}\text { Group input } \\
\text { Purchases }\end{array}$ & $\begin{array}{l}1 \text { = The household is participating in at least } 1 \text { group that is } \\
\text { purchasing farm inputs }\end{array}$ & .315 & .465 \\
\hline Contact intensity & $\begin{array}{l}\text { Frequency of discussions with other finger millet farmers (ranging } \\
\text { from } 1 \text { to 15) }\end{array}$ & 8.244 & 4.374 \\
\hline Market distance & Distance to main market (in walking minutes) & 75.896 & 71.703 \\
\hline Cell phone & $1=$ At least one household member uses a cell phone & .848 & .360 \\
\hline Extension_fm & $\begin{array}{l}1=\text { The household received finger millet extension in the past } 5 \\
\text { years }\end{array}$ & .422 & .495 \\
\hline Extension_mz & $1=$ the household received maize extension in the past 5 years & .252 & .435 \\
\hline External & $\begin{array}{l}1 \text { = The household is situated in an external location without KARI } \\
\text { intervention }\end{array}$ & .200 & .401 \\
\hline \multicolumn{4}{|l|}{ Human capital } \\
\hline Age & Age of household head (in years) & 54.468 & 13.449 \\
\hline Female_fm & $1=$ Responsible person for finger millet production is female & .493 & .501 \\
\hline Female_mz & $1=$ Responsible person for maize production is female & .444 & .498 \\
\hline Education & $\begin{array}{l}1 \text { = At least one household member has a secondary school } \\
\text { education }\end{array}$ & .496 & .501 \\
\hline $\begin{array}{l}\text { Dependency } \\
\text { Ratio }\end{array}$ & $\begin{array}{l}\text { Number of household members aged } 0-14 \text { and over } 65 \text { divided by } \\
\text { number of household members aged } 15-64\end{array}$ & 1.121 & .999 \\
\hline \multicolumn{4}{|l|}{ Wealth } \\
\hline Farm size & Total farm size (in acres) & 3.973 & 3.978 \\
\hline Cattle & Number of cattle owned by household & 2.944 & 3.133 \\
\hline Off-farm income & Off-farm households income in 2011 (in 1000 KES) & 129.436 & 507.493 \\
\hline \multicolumn{4}{|l|}{ Regional dummies } \\
\hline Teso & $1=$ Farm is located in Teso district & .333 & .472 \\
\hline Mumias & $1=$ Farm is located in Butere-Mumias district & .400 & .491 \\
\hline
\end{tabular}

Regarding the adoption of improved cropping practices in maize, we largely include the same variables as potential explanatory variables ${ }^{6}$. However, improved maize cropping practices have been propagated by extension programs for decades and formal sources of information are widely available for maize production. We therefore expect access to markets and information to be less of a constraint for the adoption of improved maize cropping practices. In particular, since nearly every

\footnotetext{
${ }^{6}$ Regarding extension, we include a dummy that equals one if the household received maize (not millet) related extension. Furthermore, we include a variable on the gender of the person responsible for maize (not millet) production.
} 
farmer in western Kenya grows maize, contact intensity among maize farmers is generally high and does not vary much between households. We therefore do not include a similar variable on contact intensity in the maize equations. In contrast, we do include the dummy variable that assumes one if households are located in external control villages in the maize equation, even though the KARI program focuses exclusively on finger millet. However, including it in the maize regressions allows us to control whether differences in the use of improved finger millet technologies reflect a systematic difference between the locations or can be interpreted as spillover effects from the KARI extension program.

\subsubsection{Yield analysis}

In order to analyze the effect of improved cropping practices on finger millet yields, we estimate a Cobb-Douglas ${ }^{7}$ production function:

$$
\ln Y_{i}=\alpha_{0}+\sum_{j=1}^{j} \alpha_{j} \ln X_{j i}+\sum_{k=1}^{k} \alpha_{k} D_{k i}+u_{i}
$$

where $Y_{i}$ is the finger millet yield (in kg per acre) for observation $i, X_{j}$ is a vector of input factors, $D_{k}$ is a vector of dummy variables and $u_{i}$ is a random error term. We include a dummy variable that equals one if the farmer has adopted an improved variety. The use of chemical fertilizer is quantified in kg per acre. Following Battese (1997), we additionally include a dummy variable that takes the value one if the input of chemical fertilizer is zero in order to avoid biased estimates caused by zero values in the quantity of chemical fertilizer used. Other continuous input variables are the quantity of seeds and the labor input for soil preparation, sowing, and weeding. Since farmers are often not able to give very accurate specifications of the amount of organic fertilizer applied, we do not include the use of organic fertilizer as a continuous variable, but instead, use a dummy variable that takes the value one if the farmer applies any organic fertilizer. In order to reflect the extent of

\footnotetext{
${ }^{7}$ Alternatively, a translog production function would increase the flexibility of the model. However, in our data set the translog functional form leads to problems of multicollinearity. We therefore choose the more restrictive Cobb-Douglas functional form.
} 
mechanization in millet production, we include a dummy that equals one if the farmer uses an ox plough or tractor for soil preparation. Another dummy variable is included to control for the application of row-planting. Furthermore, the timing of planting can have an important influence on yields. The optimal planting time depends on the start of the rainy season and varies slightly between the districts, but early planting is usually advantageous in cereal production. To differentiate between early planters and late planters, we include a dummy variable for early planting that equals one if farmers planted between December and February and zero if they planted between March and May. Finally, we include altitude and a plot specific dummy for high soil fertility to account for agro-ecological differences. Summary statistics for the variables used in the Cobb-Douglas production function are provided in Table 2.2.

\section{Table 2.2: Variables used in the Cobb-Douglas production function}

\begin{tabular}{llrr} 
Variable & Variable description & Mean & Std. Dev. \\
\hline Ln harvest per acre & Logarithm of harvest per acre (kg) & 5.321 & 1.141 \\
Ln seed quantity & Logarithm of seed quantity (kg) & 1.505 & .740 \\
$\begin{array}{l}\text { Ln chemfert } \\
\text { Ln soilprepsow lab }\end{array}$ & Logarithm of chemical fertilizer quantity (kg) & 1.830 & 1.885 \\
& Logarithm of soil preparation and sowing input & 3.434 & .885 \\
Ln weed lab & (working days) & & \\
Ox-tractor & Logarithm of weeding input (working days) & 3.519 & .851 \\
Early planting & 1 = Use of an ox-tractor & .504 & .501 \\
Row-planting & 1 = Planted between December and March & .578 & .495 \\
Modern variety & 1 = Practice of row-planting & .678 & .468 \\
Zero chemfert & 1 = Use of a modern variety & .491 & .501 \\
Orgfert & 1 = No use of chemical fertilizer & .389 & .488 \\
Altitude & 1 = Use of organic fertilizer & .337 & .474 \\
High soil fert & 1 = Altitude of dwelling (meters) & 4131.137 & 291.236 \\
\hline
\end{tabular}

As a result of unobserved factors that potentially influence both the probability of adopting an improved variety and finger millet yields (e.g. the farmer's motivation), estimates of the CobbDouglas function might be biased. To control for potential selection bias, we estimate a treatment effects model in which an auxiliary probit model estimates the probability of adopting a modern variety. The inverse Mill's ratio of the probit model is then included as a selectivity correction in the Cobb-Douglas regression. The variable 'external' serves as an exclusion restriction in our treatment effects model. Being located in an external location is likely to have a negative impact on the 
probability of adopting a modern variety, since farmers in external locations do not easily access the information given by KARI extension services. At the same time, the variable is unlikely to be directly related to finger millet yields, except for its effect through the improved practices. A selectivity bias is present when the error terms between the two regressions of the treatment effects model are correlated $(\rho \neq 0)$.

\subsection{Descriptive results}

With an average farm size of four acres (1.6 hectares), most households in our sample are smallscale farmers. During the long-rains in 2011, farmers dedicated 0.84 acres to the production of finger millet and 1.32 acres to the production of maize, on the average. Although we did not explicitly sample maize producers, only 14 farmers in our sample did not grow any maize during the long-rains and only three farmers did not grow any maize in 2013.

\subsubsection{Adoption of improved cropping practices}

Improved finger millet cropping practices applied by farmers in our sample include the use of modern varieties and chemical fertilizer as well as enhanced planting and weeding practices. Modern finger millet varieties have only been commercially available for a few years and are not yet widely used in western Kenya. Accordingly, a relatively large share of the farmers in our sample (34.1\%) is not aware of any modern finger millet varieties. Similarly, fertilizer application is not a common practice in finger millet production and many farmers rely on the crop's resilience to poor soils. In fact, $21.5 \%$ of the interviewed farmers indicated that they have never observed fertilizer application in finger millet production. Other practices such as row-planting, weeding and thinning are well known to over $90 \%$ of the farmers. The relatively high share of farmers that are not aware of modern varieties and chemical fertilizer applications in finger millet production suggests that lack of information may be an important reason for non-adoption in our sample. 
Among the interviewed farmers, $49.1 \%$ used a modern finger millet variety in 2011 and $54.1 \%$ applied chemical fertilizer to their finger millet production area. Micro-dosing was practiced by $38.3 \%$ of the farmers who applied chemical fertilizer. With respect to planting techniques, we find that $67.8 \%$ of the farmers practice row-planting and $42.2 \%$ of the farmers are early planters with planting dates between December and February. Our survey data shows little variation of the weeding and thinning practices: While only one farmer did not weed at all and over $90 \%$ of the farmers thinned their finger millet during the first weeding, less than $5 \%$ of all farmers conducted a second weeding ${ }^{8}$.

As shown in Table 2.3 important synergies seem to be associated with the use of the same practices in maize and millet production. Adoption rates of improved technologies are generally higher in maize production, with $71.1 \%$ of the interviewed farmers using an improved maize variety and $61.5 \%$ applying chemical fertilizer in maize production. Among the adopters of a modern maize variety, $54 \%$ also use a modern finger millet variety. Among the non-adopters of a modern maize variety, only $35 \%$ cultivated a modern finger millet variety in 2011 . Likewise, $72 \%$ of the farmers who use chemical fertilizer in maize production also use it in finger millet production, while only $25 \%$ of the farmers who to not apply fertilizer in maize production use fertilizer in finger millet production.

\footnotetext{
${ }^{8}$ It is important to keep in mind that farmers who have received finger millet related extension are oversampled in our data and that the simple descriptive adoption rates presented here are therefore not representative for the whole region in the case of finger millet.
} 
Table 2.3: Relationship between maize and finger millet cropping practices

\begin{tabular}{lllll} 
& \multicolumn{2}{l}{ Modern variety (maize) } & \multicolumn{2}{l}{ Fertilizer (maize) } \\
\cline { 2 - 5 } & Non-adopters & Adopters & Non-adopters & Adopters \\
\hline Modern variety (finger millet) & $.35(.48)$ & $.54(.50)^{* * *}$ & & \\
Fertilizer (finger millet) & & & $.25(.43)$ & $.72(.45)^{* * *}$ \\
\hline
\end{tabular}

Values in brackets are standard deviations

$* * *$ indicates a correlation between the adoption of a practice in maize and finger millet production on a $1 \%$ significance level (based on chi $^{2}$ test)

\subsubsection{Participation in farmer groups}

As described in the previous section, variables related to social networks and connectedness can alleviate adoption constraints by improving access to information, labor, cash, and product markets. In our research area, social networks and groups play an important role. The great majority of households in our sample (85.9\%) participate in at least one active social group. Most households (77.4\%) are member in one to three groups, while $8.5 \%$ participate in more than three groups. The social groups are very diverse regarding their members and activities, including for example self-help groups for widows, youth groups or church groups. Among the households who participate in at least one group, $36.6 \%$ purchase farm inputs together with other group members.

When asked about their contact to other finger millet farmers, $11 \%$ of the interviewed farmers claimed not to be in contact with any other finger millet farmer. A total of $21 \%$ stated to be in contact with one or two other finger millet farmers, while a majority of $68 \%$ indicated to be in contact with three or more other finger millet farmers. As described in Chapter 4, we asked finger millet farmers how often they discuss their cropping practices with other finger millet farmers on a scale from one ("never") to five ("very often"). Most farmers (53\%) responded that they discuss cropping practices often or very often. Practices are never or rarely discussed in $17 \%$ of the cases and sometimes discussed in $31 \%$ of the cases. 


\subsubsection{Finger millet yields}

Regarding finger millet yields, we find significantly higher yields among adopters than among nonadopters of improved finger millet cropping practices (see Table 2.4). For example, farmers who use a modern variety obtain an average yield of $420 \mathrm{~kg}$ per acre as compared to an average yield of 235 kg per acre among farmers who do not use a modern variety.

Similarly, we find significantly higher maize yields among farmers who use a modern variety and chemical fertilizer in maize production. We furthermore find a major discrepancy between finger millet and maize yields; while the average finger millet yield ranges at $330 \mathrm{~kg}$ per acre, we observe an average maize yield of $603 \mathrm{~kg}$ per acre.

Table 2.4: Average yields per acre

\begin{tabular}{llllllll} 
& \multicolumn{2}{l}{ Modern variety } & Fertilizer & \multicolumn{2}{l}{ Row-planting } \\
\cline { 2 - 7 } & $\begin{array}{l}\text { Non- } \\
\text { adopters }\end{array}$ & Adopters & $\begin{array}{l}\text { Non- } \\
\text { adopters }\end{array}$ & Adopters & $\begin{array}{l}\text { Non- } \\
\text { adopters }\end{array}$ & Adopters & All \\
\hline $\begin{array}{l}\text { Finger millet } \\
\text { yields (in kg }\end{array}$ & 234.93 & 420.31 & 217.92 & 423.69 & 201.78 & 387.51 & 327.67 \\
per acre) & $(211.56)$ & $(333.77)^{* * *}$ & $(196.23)$ & $(329.27)^{* * *}$ & $(182.59)$ & $(316.76)^{* * *}$ & \\
$\begin{array}{l}\text { Maize yields } \\
\text { (in kg per acre) }\end{array}$ & 398.92 & 689.12 & 290.37 & 776.72 & & \\
\hline $\begin{array}{l}\text { Values in brackets are standard deviations } \\
* * *\end{array}$ & $(331.85)$ & $(589.77)^{* * *}$ & $(252.73)$ & $(582.82)^{* * *}$ & & \\
\end{tabular}

When asking farmers about their main yield constraints in finger millet production, the availability and costs of inputs were mentioned as the most important constraint by $36 \%$ and as the second most important constraint by $33 \%$ of the households (see Table 2.5 ). Another important constraint mentioned by farmers is poor crop management, which was mentioned as the most important constraint by $27 \%$ of the farmers. These answers can reflect both poor access to financial capital and input markets as well as lack of skills and information. Other important constraints mentioned include erratic rainfall, pests, diseases, and poor soils. 
Table 2.5: Main yield constraints in finger millet production (farmers' perception)

\begin{tabular}{lllll} 
Main constraints & Access to inputs & $\begin{array}{l}\text { Poor crop } \\
\text { management }\end{array}$ & $\begin{array}{l}\text { Erratic rainfall, } \\
\text { pests, diseases }\end{array}$ & Poor soils \\
\hline I & $96(36 \%)$ & $72(27 \%)$ & $68(25 \%)$ & $26(10 \%)$ \\
II & $90(33 \%)$ & $46(17 \%)$ & $66(24 \%)$ & $14(5 \%)$ \\
III & $47(17 \%)$ & $22(8 \%)$ & $42(16 \%)$ & $9(3 \%)$ \\
\hline
\end{tabular}

\subsubsection{Results on the adoption of improved practices}

Table 2.6 presents the results on the adoption of improved cropping practices in finger millet production from the multivariate probit model. As expected, variables related to social networks and connectedness play an important role in the adoption of improved finger millet cropping practices. The contact intensity with other finger millet farmers has a positive influence on the adoption of both cropping practices. Furthermore, the ownership of a cell phone increases the likelihood of using a modern variety and chemical fertilizer by $31 \%$ and $33 \%{ }^{9}$, respectively, pointing to the importance of cell phones for accessing input markets. In terms of group membership, participating in a group where members jointly purchase certain farm inputs increases the probability of adopting a modern variety by $25 \%$, but is insignificant in the case of chemical fertilizer. As opposed to modern finger millet varieties, chemical fertilizer is an input that has widely been used by small-scale farmers in the region for many years. Access to chemical fertilizer is therefore rather limited by cash constraints than by market information constraints and farmers who can afford to purchase chemical fertilizer do not need to buy this input through a group. For a new and less accessible input like improved finger millet varieties, collective purchasing is effectively increasing the farmers' access to this input. As expected, the reception of extension services fosters the adoption of both practices. We furthermore observe a negative effect of the external location dummy on the adoption of both practices. This indicates that spillover-effects exist within program villages, where

\footnotetext{
${ }^{9}$ We calculated the marginal effects by introducing an observation where all variables equal the mean value of that variable. The marginal effect of a dummy variable is measured as the change in the predicted probability of that observation due to a change of the dummy value from zero to one. The marginal effect of a continuous variable is measured as the change in the predicted probability due to an increase of the mean value by 1 . In the case of off-farm income, the mean value was increased by $1 \%$ to measure the marginal effect.
} 
farmers are more likely to adopt modern practices in millet cultivation, even if they did not actively participate in trainings.

The variables reflecting household wealth have a positive effect on the use of chemical fertilizer, confirming our hypothesis that the non-adoption of chemical fertilizer can rather be attributed to a cash constraint than to information constraints. Finally, the district dummies reveal regional differences in the dissemination of modern finger millet production practices: compared to the excluded district Busia, farmers in Teso are less likely to practice improved finger millet cropping practices.

Table 2.6: Regression results on the adoption of improved finger millet practices

\begin{tabular}{|c|c|c|c|c|c|c|}
\hline & \multicolumn{3}{|c|}{ Modern variety } & \multicolumn{3}{|c|}{ Chemical fertilizer } \\
\hline & Coefficient & & Standard Error & Coefficient & & Standard Error \\
\hline Female_fm & $.125(.050)$ & & .220 & $.128(.049)$ & & .215 \\
\hline Age & $.010(.004)$ & & .009 & $.014(.005)$ & & .010 \\
\hline Education & $-.203(-.081)$ & & .236 & $-.166(-.063)$ & & .233 \\
\hline Dependency ratio & $-.034(-.013)$ & & .104 & $.034(.031)$ & & .087 \\
\hline Farm size & $.046(.018)$ & & .042 & $-.001(-.001)$ & & .040 \\
\hline Off-farm income & $.000(.000)$ & & .000 & $.000(.002)$ & $* * *$ & .000 \\
\hline Cattle & $-.039(-.016)$ & & .036 & $.083(.031)$ & $* *$ & .037 \\
\hline Group number & $.000(.000)$ & & .110 & $-.010(-.004)$ & & .105 \\
\hline Group purchase & $.646(.253)$ & $* *$ & .270 & $.343(.126)$ & & .315 \\
\hline Contact intensity & $.090(.036)$ & $* * *$ & .032 & $.087(.033)$ & $* * *$ & .028 \\
\hline Cell phone & $.840(.308)$ & $* *$ & .349 & $.843(.326)$ & $* * *$ & .387 \\
\hline Market distance & $-.002(-.001)$ & & .002 & $-.002(-.001)$ & & .002 \\
\hline Extension_fm & $1.306(.486)$ & $* * *$ & .239 & $1.112(.391)$ & $* * *$ & .271 \\
\hline External & $-.811(-.303)$ & $* * *$ & .316 & $-.971(-.373)$ & $* * *$ & .270 \\
\hline Mumias & $-.213(-.084)$ & & .293 & $.285(-.106)$ & & .296 \\
\hline Teso & $-.615(-.240)$ & $* *$ & .298 & $-1.180(-.437)$ & $* * *$ & .313 \\
\hline Constant & -2.236 & $* * *$ & .785 & -2.375 & $* * *$ & .852 \\
\hline
\end{tabular}

Results from the maize equations of the multivariate probit model can be found in Table 2.7. Clearly, social and market connectedness pose less of a constraint to the adoption of improved crop management practices in maize production. The only variable that is significant is the number of 
groups a household participates in, which has a positive influence on the adoption of modern maize varieties. This confirms our hypothesis that social and market connectedness is much more critical in the case of a neglected crop, like finger millet, for which formal sources of information are scarce. Furthermore, some of the human capital and wealth related indicators have a significant effect on the adoption of modern varieties and chemical fertilizer in maize production. In particular, age has a negative sign, indicating that younger farmers are more innovative, and the number of cattle has a positive sign, providing some evidence that wealthier households may be less cash constrained. Finally, farmers in external locations are less likely to use chemical fertilizer not only in millet but also in maize production, indicating that general access to agrochemical input stores might be more limited in those villages. 
Table 2.7: Regression results on the adoption of improved maize cropping practices

\begin{tabular}{|c|c|c|c|c|c|c|}
\hline & \multicolumn{3}{|c|}{ Modern variety } & \multicolumn{3}{|c|}{ Chemical fertilizer } \\
\hline & Coefficient & & Standard & Coefficient & & Standard \\
\hline & & & Error & & & Error \\
\hline Female_mz & $-.143(-.046)$ & & .212 & $-.146(-.051)$ & & .216 \\
\hline Age & $-.014(-.004)$ & $*$ & .008 & $-.013(-.005)$ & & .009 \\
\hline Education & $.129(.041)$ & & .211 & $.238(.083)$ & & .214 \\
\hline Dependency ratio & $-.116(-.039)$ & & .085 & $.110(.037)$ & & .130 \\
\hline Farm size & $-.059(-.019)$ & $* *$ & .030 & $-.034(-.012)$ & & .031 \\
\hline Off-farm income & $.000(.000)$ & & .000 & $.000(.000)$ & & .000 \\
\hline Cattle & $.135(.041)$ & $* * *$ & .041 & $.114(.039)$ & $* * *$ & .043 \\
\hline Group number & $.248(.072)$ & $* *$ & .103 & $.141(.047)$ & & .102 \\
\hline Group purchase & $.111(.035)$ & & .267 & $.028(.010)$ & & .276 \\
\hline Cell phone & $.153(.050)$ & & .306 & $.221(.080)$ & & .346 \\
\hline Market distance & $-.000(-.000)$ & & .001 & $-.000(-.000)$ & & .001 \\
\hline Extension_mz & $-.027(-.009)$ & & .252 & $.027(.009)$ & & .248 \\
\hline External & $.183(.056)$ & & .249 & $-.800(-.300)$ & $* * *$ & .227 \\
\hline Mumias & $.230(.071)$ & & .267 & $1.129(.343)$ & $* * *$ & .291 \\
\hline Teso & $.364(.113)$ & & .266 & $-.276(-.097)$ & & .252 \\
\hline Constant & .512 & & .636 & .169 & & .761 \\
\hline
\end{tabular}

Marginal effects are given in parentheses.

$* * *, * *$, and $*$ indicate a significance level of $1 \%, 5 \%$, and $10 \%$, respectively

The rho values reported in Table 2.8 reflect the correlation between the error terms of the equations. The error terms of the two finger millet equations are positively and significantly correlated, indicating synergies rather than trade-offs in the adoption of improved crop management practices in finger millet production systems. Likewise, the error terms of the maize equations are positively correlated. Regarding the adoption of the same practice for different crops, we find synergies in the adoption of chemical fertilizer in finger millet and maize production. Similarly, the error terms of the equations for modern maize variety adoption and modern finger millet variety adoption are also positively correlated. These results indicate that synergies exist in the adoption of improved crop management practices within and across cropping systems that result from reduced transaction costs as well as knowledge spillovers from maize to finger millet production. 
Table 2.8: Model statistics of the adoption analysis

Rho value Coefficient Standard Error

Interaction millet practices

Rho21 (finger millet fertilizer / finger millet modern variety)

.626

Interactions maize practices

Rho43 (maize fertilizer / maize modern variety)

$.600 * * *$

Interactions millet and maize practices

Rho31 (maize modern variety / finger millet modern variety)

$.278 * *$

Rho32 (maize modern variety / finger millet fertilizer)

$.278 * * \quad .022$

Rho41 (maize fertilizer / finger millet modern variety)

.067

Rho42 (maize fertilizer / finger millet fertilizer)

\begin{tabular}{lrlr}
\hline $\mathrm{N}$ & 250 & Prob>Chi & \\
Wald $\mathrm{Chi}^{2}(78)$ & 449.030 & Log pseudolikelyhood & -1757.972 \\
\hline
\end{tabular}

\subsection{Yield effects of improved cropping practices}

Table 2.9 reports the results of the Cobb-Douglas production function estimating yield effects of improved finger millet practices. The hypothesis that rho $=0$ is rejected in the treatment effects model (Prob $>$ Chi2 $=0.05$ ), indicating the presence of a selection bias ${ }^{10}$. Coefficients in the CobbDouglas production function represent the partial production elasticities of the different input variables and can thus be interpreted as percentage changes. Results show that the adoption of a modern finger millet variety has a positive and significant impact, increasing yields by $107 \%{ }^{11}$. Furthermore, chemical fertilizer applications have positive yield effects. According to our results, an increase in the quantity of chemical fertilizer by $1 \%$ leads to a yield increase of $0.16 \%$. Finally, the quantity of seeds applied has a positive effect on finger millet yields.

\footnotetext{
${ }^{10}$ First stage results of the treatment effects model are presented in Table A.1 in the annex.

${ }^{11}$ Since the dependent variable is a log-dependent variable, coefficients of dummy variables are interpreted as $[\exp ($ coefficient)-1]*100.
} 
Table 2.9: Cobb-Douglas production function

\begin{tabular}{|c|c|c|c|}
\hline Variable & Coefficient & & Standard Error \\
\hline Ln seed quantity & .268 & $* * *$ & .096 \\
\hline Ln chemfert & .159 & $* * *$ & .047 \\
\hline Ln soilprepsow lab & .001 & & .114 \\
\hline Ln weed lab & .156 & & .096 \\
\hline Ox-tractor & .350 & & .176 \\
\hline Early planting & .203 & & .168 \\
\hline Row-planting & .024 & & .241 \\
\hline Modern variety & .729 & $* * *$ & .266 \\
\hline Zero chemfert & -.188 & & .202 \\
\hline Orgfert & .104 & & .180 \\
\hline High soil fert & -.047 & & .164 \\
\hline Altitude & -.000 & & .000 \\
\hline Constant & 4.333 & $* * *$ & .904 \\
\hline $\mathrm{N}$ & 267 & og pseudolikelihood & -1805.372 \\
\hline Wald Chi ${ }^{2}(12)$ & 104.490 & Vald test of indep. Eqns. $(r h o=0): \operatorname{chi}^{2}(1)$ & 3.860 \\
\hline Prob $>\mathrm{Chi}^{2}$ & .000 & $\mathrm{rob}>\mathrm{Chi}^{2}$ & 0.050 \\
\hline
\end{tabular}

$* * *$ indicates a significance level of $1 \%$

\subsection{Conclusions}

To increase agricultural productivity in rural areas of developing countries, the dissemination of improved agricultural technologies needs to be stimulated. While previous and current research dedicated to this topic usually focuses on cash crops or main food crops such as maize, rice and wheat, traditional cereals like finger millet have been widely neglected despite their importance for many small-scale farmers worldwide. Based on cross-sectional household data from 270 finger millet farmers, the present study analyzes the adoption of modern varieties and chemical fertilizer among finger millet farmers in western Kenya. We furthermore assess the use of the same practices in maize production in order to compare adoption processes for a traditional cereal with adoption processes for a main staple crop.

Results of a multivariate probit analysis show that variables related to social networks and connectedness have a substantial influence on the adoption of improved finger millet technologies. 
Specifically, we find contact intensity among finger millet farmers, the use of a cell phone and extension to have a positive effect on the adoption of improved finger millet practices. At the same time, these variables are found to be of minor importance for the adoption of the same practices in maize production. The error terms of the different equations are positively correlated, indicating complementarities rather than trade-offs between modern variety adoption and fertilizer applications for the same crop, but also across crops. Furthermore, results of a Cobb-Douglas production function demonstrate a strong positive effect of the adoption of modern varieties and chemical fertilizer on finger millet yields.

Our findings indicate that improved cropping practices for traditional food crops are widely applied once the prevailing constraints such as lack of information and access to inputs can be overcome. While in the case of maize the effect of extension on adoption is negligible in our research area, extension plays a critical role for the adoption of improved finger millet practices. These differences can be attributed to the fact that knowledge about maize cropping practices is widely available, while knowledge regarding improved finger millet practices is scarce. Furthermore, while traditional crops have a lower yield potential than main staple crops under ideal growing conditions, the strong yield effect of improved practices in our analysis shows that there is a substantial untapped yield potential in finger millet production.

Therefore, policy-makers aiming to promote the use of modern inputs in neglected traditional crops should support targeted extension programs. Extension programs dedicated to traditional crops can disseminate knowledge on best practices and at the same time improve the crops' reputation, thus encouraging farmers to unleash the full potential of traditional food crops. This is especially important against the background that finger millet and other traditional food crops can play a crucial role for the resilience of agricultural systems and the micronutrient supply of the rural population.

Besides formal extension, farmer-to-farmer networks are found to be an effective trigger for the dissemination of finger millet practices. In rural Kenya, many social groups exist and the majority of 
farmers participate in at least one group. However, group activities vary widely and can be a decisive factor for the diffusion of new technologies. In particular, joint input purchases may help farmers to overcome high transaction costs associated with accessing improved technologies. To facilitate these activities, training social groups on group organization and management might be as important as the training on agricultural practices itself to ensure a broad adoption of improved practices. 
Improved production systems for traditional food crops 


\title{
Part three
}

\section{Traditional food crop marketing in Sub-Saharan Africa:}

\section{does gender matter? ${ }^{12}$}

\begin{abstract}
$\underline{\text { Abstract: }}$
The present study aims to contribute to the scarce literature on traditional food crop marketing by analyzing the factors influencing (a) the household's decision to participate in the market and (b) the selling prices obtained by the household. Using an econometric approach, we analyze household data from 270 finger millet producers in western Kenya. A main focus of the study lies on the role of gender and collective action. Results show that collective action increases the probability of market participation and is of particular importance for female farmers, who obtain higher selling prices when participating in a group.
\end{abstract}

${ }^{12}$ Submitted to World Development in July 2013, resubmitted in January 2014 


\subsection{Introduction}

Many small-scale farmers in Sub-Saharan Africa suffer from persistent poverty and food insecurity. Besides the improvement of agricultural practices, specialization and commercialization of agricultural production has been shown to benefit small-scale farmers in developing countries (von Braun 1995; Maertens \& Swinnen 2009; Rao \& Qaim 2011). Yet, many farmers have not been able to enter agricultural markets due to high transaction costs that result from market risks, deficient infrastructure and little coordination along the value chain (Key et al. 2000; Barrett 2008; Shiferaw et al. 2008).

In order to participate in agricultural markets and increase their farm incomes, small-scale farmers often turn to typical cash crops such as cotton and coffee or to high-value crops, especially fresh fruits and vegetables. Cash crops and high-value crops have a high income potential and are important for the livelihoods of many farmers worldwide. However, transaction costs are particularly high in these markets. Specializing on cash crops often entails high risks due to high input costs, considerable price volatility, and a dependency on one or a few large buyers (Poulton et al. 2004; Gemech \& Struthers 2007). Another barrier to specializing in the production of cash crops that cannot be consumed by the household is high food price volatility, which forces farmers to prioritize on food crop production (Fafchamps 1992). In the case of fruits and vegetables, transaction costs for entering high value markets are particularly high due to increasingly complex food safety and quality requirements (Reardon et al. 2009; Kersting \& Wollni 2012; Handschuch et al. 2013). Existing literature suggests that high fixed transaction costs of entering high-value markets exclude especially the smallest and least endowed farmers (Maertens \& Swinnen 2009; Handschuch et al. 2013).

In general, barriers to commercialization are often found to be especially high for female farmers. For example, female farmers have less access to credits and as a result less access to inputs that are needed for market-oriented agricultural production (Zeller et al. 1998; Quisumbing \& Pandolfelli 
2010). Cash cropping is considered a male domain in most parts of Sub-Saharan Africa, while women are often responsible for the production of subsistence food crops. The male domination of cash crops can have negative impacts on food security, especially when the cash crop area is expanded at the expense of food crops (Kiriti \& Tisdell 2003). It has been shown that female incomes have a stronger positive effect on household food expenditures and food security than male incomes (Hoddinott \& Haddad 1995; Fischer \& Qaim 2012a).

One possibility of increasing market access for small-scale farmers is the organization of farmers in farmer groups. Group marketing has the potential to reduce transaction costs and increase the bargaining power of small-scale farmers (Roy \& Thorat 2008). Farmer groups furthermore facilitate farmers' access to inputs and information on improved cropping practices (Fischer \& Qaim 2012b). Existing literature shows that producer marketing groups (PMGs) or other forms of farmer collective action can increase market access and the income derived from the marketing of agricultural products (Kaganzi et al. 2009; Narrod et al. 2009; Wollni et al. 2010). On the other hand, there is no guarantee for the success of farmer collective action. Returns to collective action vary depending on group characteristics, product characteristics, and other factors (Markelova et al. 2009). Moreover, female farmers might be the ones excluded from the benefits of farmer collective action. In their study on banana marketing in Kenya, Fischer and Qaim (2012a) conclude that participation in mainly male dominated PMGs leads to an increased male control over the crop and the income derived from it. While the formation of women groups may prevent this development, Barham and Chitemi (2009) show that female PMGs are disadvantaged in terms of market access when compared to male dominated PMGs.

Despite the large amount of literature dedicated to smallholder market access, very little attention has been given to the marketing of food crops. Selling traditional food grains like finger millet could be a viable income alternative, especially for those farmers who are excluded from cash crop and high-value markets. Furthermore, food grains are usually female crops and therefore have the 
potential to increase female incomes. As opposed to many cash crops, food grains can be consumed by the household in case of unfavorable markets or food shortage, which decreases market risks and increases food security. The good storability and easy handling of food grains further reduce marketing risks, leading to lower transaction costs and reduced marketing barriers. For example, farmers can store finger millet without incurring high investments in storage facilities and without the risk of high losses occurring from storage pests. However, transaction costs and market risks are not absent in the often poorly developed food grain markets and can still represent substantial market barriers for small-scale farmers (Barrett 2008). An important work concerning transaction costs in the food grain sector was done by Goetz (1992), who modeled the negative effect of transaction costs and missing market information on the marketing of coarse grains by smallholders. Similarly, Key et al. (2000) show that Mexican maize producers opt for self-sufficiency when transaction costs for marketing are too high. The important role that collective action can play for the marketing of traditional cereals is stressed by Gruère et al. (2009), who conducted a qualitative study on the marketing of minor millets in India. Bernard et al. (2008) assess the impact of collective action on food grain marketing, but do not specifically focus on traditional cereals.

This article aims to add to the sparse literature on food grain marketing by assessing the marketing of finger millet among small-scale farmers in western Kenya. Among the food grains grown in Kenya, finger millet is known for its nutritional value, high market prices, little price volatility, adaptability to unfavorable agro-ecological conditions, and good storability (Oduori 2005; Oduori \& Kanyenji 2007). Despite the potential of finger millet, it has hardly been given any attention by researchers and policy makers in the past decades. Based on a household survey among 270 finger millet producers, we analyze the factors that determine (1) the decision of farmers to participate in the finger millet market and (2) the selling price obtained by farmers. The main focus of our analysis is on the genderspecific effects and on the role of collective action for market participation and prices. The remainder of the article is organized as follows. The next section gives an overview of the Kenyan 
finger millet market. Sections three and four present our data collection approach and the methodology applied. Descriptive and econometric results are described in sections five and six, respectively. Finally, we summarize our findings and point out policy implications in section seven.

\subsection{The Kenyan finger millet market}

The production of finger millet and its importance as a main staple food have declined dramatically in the past decades, as farmers have continually increased their maize production area at the expense of traditional food grains (Crowley \& Carter 2000). Compared to maize, finger millet is better adapted to poor agro-ecological conditions and could therefore make an important contribution towards more resilient agro-ecological systems, especially against the background of climate change and ongoing soil degradation. Furthermore, the highly nutritious crop is seen as a key to improve food security in terms of micronutrient supply (National Research Council 1996; Oduori 2005).

Despite the declining importance of finger millet as a main staple food, demand is still high since the crop is appreciated as a valuable food for diabetics, infants, pregnant women, HIV patients, as well as for special occasions such as weddings and for brewing beer. Finger millet prices are high and have been well above the prices for maize and other cereals in the past years (Oduori 2005). Market prices for the year 2011 are depicted in Figure 3.1 and show that throughout the year finger millet prices were not only higher, but also less volatile than maize prices. The average market price in 2011 was 52 Kenyan Shillings (KES) for finger millet and 31 KES for maize. Finger millet is mainly traded on the spot market and farmers sell their produce to local traders, neighbors, or on the local market without formal contractual agreements. Some farmers try to increase their earning from finger millet by selling value added products such as beer or cookies. Selling finger millet residues as cattle or poultry fodder is another possible source of income. 
Figure 3.1: Kenyan grain market prices in 2011

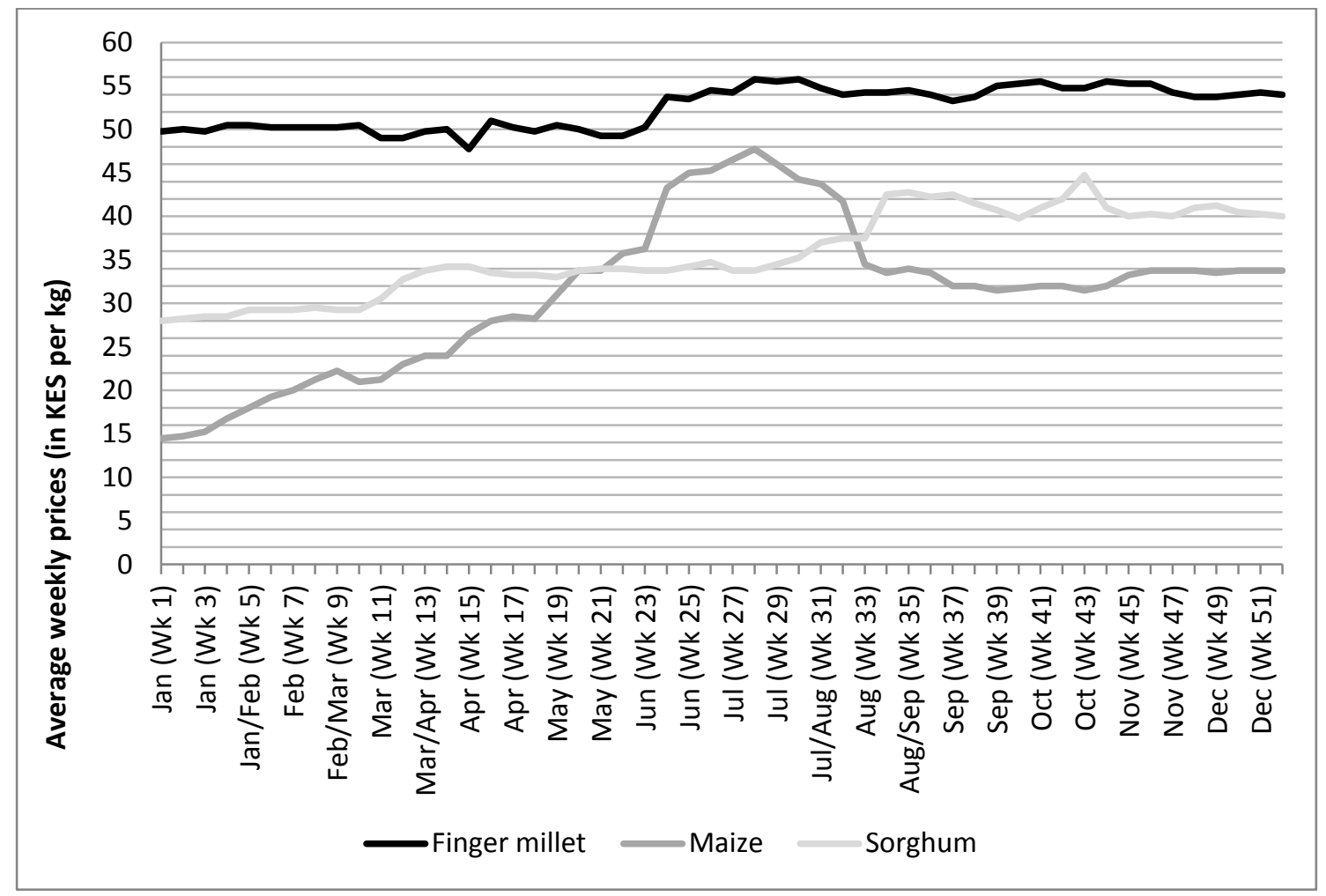

Source: Kenyan Agricultural Commodity Exchange (KACE)

Despite the existence of official market prices and a few larger finger millet traders and processors, the bulk of finger millet sales happens at the local and small-scale level. Reliable information on the structure and organization of the finger millet market is therefore scarce. To get a clearer picture, we interviewed several actors of the finger millet value chain, including farmer groups, local traders, and processors. In addition, the International Crops Research Institute for the Semi-Arid Tropics (ICRISAT) provided us with information from interviews with farmer groups and larger finger millet processors. 
A total of six local traders were interviewed in June 2012, two in each district of the research area. Altogether, we identified four procurement strategies: (1) The traders buy from farmers on market days and sell outside of market days, (2) the traders buy from intermediaries smuggling finger millet from Uganda ${ }^{13}$, (3) the traders travel to Uganda themselves to buy finger millet on the local market, and (4) the traders have the phone contact of finger millet farmers and buy from them at the farm gate.

The large amount of finger millet that is procured from Uganda reflects the scarcity of finger millet on the Kenyan market. All interviewed traders stated that they would like to buy more finger millet, but are constrained by local supplies. The traders complained about quality problems with finger millet from Uganda, which is often soiled with large amounts of sand and stones. Traders who buy at the farm gate usually have the phone number of key farmers, e.g. group leaders, who act as (free) intermediaries for other finger millet farmers. Trading margins are higher for finger millet than for maize. For example, one trader stated that she is currently buying finger millet for 100 KES per gorogoro $^{14}$ and selling it for 120 KES per gorogoro, while buying maize at 50 KES per gorogoro and selling it at 55 KES per gorogoro. The high trading margins for finger millet are one indication for the general scarcity of information on finger millet prices as compared to information on maize prices. Farmer groups engaged in finger millet activities follow different strategies to facilitate finger millet marketing. Many farmers simply get in contact with buyers through a well-connected group leader or obtain important market information from each other. In some cases, the group leader acts as a trader buying from other finger millet producers and selling (with or without margin) to larger traders. Other groups bulk their harvest for a larger buyer and negotiate a common selling price for all members.

\footnotetext{
${ }^{13}$ Despite trade liberalization between Kenya and Uganda in the past years, cross-border trade is still associated with high administrative costs and other non-tariff barriers. As a result, for many agricultural commodities a large share of cross-border trade is carried out through informal channels (Ackello-Ogutu, Echessah 1997).

${ }^{14}$ Gorogoro is a volume measure and roughly equivalent to $2 \mathrm{~kg}$ of grains.
} 
Although most of Kenya's finger millet is marketed and consumed locally, there are large finger millet traders and processors in the country. Unga Mills, the country's third largest processor of finger millet, processes about 500 tons of finger millet per month. According to Unga Mills representatives ${ }^{15}$, it is difficult to find larger quantities of finger millet in Kenya and all of their finger millet is therefore sourced through middlemen in Uganda. Unga Mills tried to establish supplier relationships with farmer groups in Eldoret and Western Province, but did not succeed in their endeavor. According to the company, small-scale farmers in Kenya do not consider finger millet as a business and currently are not able to provide the crop in sufficient quantities. On the other hand, several of the farmer groups interviewed in 2011 claimed to lack good marketing opportunities that would allow them to bulk their produce and sell to larger buyers instead of selling small quantities in the market. One of the groups had been in a commercial relationship with Unga Mills, which failed according to the group because of their inability to supply the required minimum quantities and due to the delayed payments by the company. Overall, communication and coordination along the millet value chain in western Kenya is very limited. On the one hand, local traders and large processors have an unmet demand for locally produced finger millet. On the other hand, small-scale farmers have little access to reliable market information. This is notwithstanding the fact that market information services that aim to link farmers with buyers are available. The Kenyan Agricultural Commodity Exchange (KACE) for example provides market price information through text message services and radio broadcasts. In addition, for a small commission KACE offers to facilitate farmer group formation and links them with buyers. This service, however, has only been used by one finger millet farmer group and one finger millet buyer in 2011.

\footnotetext{
${ }^{15}$ Unga Mills representatives were interviewed by ICRISAT in December 2010.
} 


\subsection{Data collection}

Our research is based on a household survey among 270 finger millet farmers in Western Province. While finger millet used to be a main staple crop in the area, it was largely replaced with maize and is nowadays only grown by a minority of farmers. Acknowledging the untapped potential of finger millet in terms of food security and farm household incomes, the Kenyan Agricultural Research Institute (KARI) implemented a finger millet extension program in western Kenya. The main goal of the extension program was to promote modern finger millet varieties and improved finger millet cropping practices, but KARI also provided information on marketing and value addition. To reach the farmers, KARI contacted existing village groups and those who showed interest were subsequently used as platform for the extension program.

We interviewed farmers from 15 locations in the districts of Busia, Teso, and Butere-Mumias ${ }^{16}$. These three districts represent the focus area of the KARI extension program and vary with respect to their farming systems. Teso is a relatively remote region of Western Province, were finger millet still plays an important role in peoples' diets and farming systems. Cotton and tobacco are grown as cash crops, but mostly the region is dominated by subsistence agriculture. In contrast, farmers in Butere-Mumias tend to practice a more modernized and commercialized agriculture with sugarcane being the most important cash crop. Finger millet is of minor importance in Butere-Mumias. Geographically and in terms of agricultural production systems, Busia is located between Teso and Butere-Mumias. Using a stratified sampling design, we randomly chose twelve locations from around 32 KARI intervention locations and three locations where no interventions had taken place. Lists containing all farmers who cultivated finger millet in 2011 were compiled with the help of group leaders and village elders. In each of the twelve KARI intervention locations, we randomly selected nine members and nine non-members of the village group that had received KARI extension. In each

\footnotetext{
${ }^{16}$ The administrative areas in Kenya were regularly subject to reforms that split districts into smaller units. The last district reform took place in 2007, were e.g. Teso District was split into Teso North and Teso South. For reasons of simplicity, we are referring to the district boundaries of the 8 districts that existed before the 2007 reform.
} 
of the three non-KARI intervention locations, we randomly selected 18 finger millet farmers. We used a standardized questionnaire to obtain information on household characteristics as well as finger millet cropping and marketing practices. All production and marketing data refer to the year 2011. Since our stratified sampling design oversamples beneficiaries of the KARI extension program, we use sampling weights in the econometric analysis ${ }^{17}$.

\subsection{Methodology}

We use an econometric approach to analyze the farmer's market participation decision and the selling price obtained by the farmer. Farmers who market their produce usually receive effective selling prices below the actual market price. The gap between the effective selling price and the actual market price is determined by household-specific transaction costs. A farmer will only decide to sell his or her product when the shadow price, i.e. the opportunity cost of selling the produce in the market, is lower than the effective selling price (de Janvry et al. 1991). We model the decision to sell finger millet in a probit regression:

$$
y_{i}^{*}=X_{i}^{\prime} \beta+\varepsilon_{1 i}
$$

where $y_{i}^{*}$ represents the expected utility of farmer $i$ from participating in the market, $X$ is a vector of variables influencing the expected utility, $\beta$ is a vector of parameters to be estimated, and $\varepsilon$ is a normally distributed error term with mean zero and variance one. While we cannot directly observe the expected utility of market participation, we do observe $y_{i}=1$, if the expected utility of market participation is greater than the shadow price of the produce and $y_{i}=0$ otherwise.

The vector $X$ contains variables that are likely to influence the transaction costs and opportunity costs of marketing the produce. Farmland in Sub-Saharan Africa is mostly owned by men, who allocate parts of the land to their wives and other household members. Women are typically in

\footnotetext{
${ }^{17}$ The use of sampling weights is debated, in particular, when we are concerned about behavioral models that are heterogeneous across the population. On the other hand, not using sampling weights will lead to biased and inconsistent estimates of the model parameters (Deaton 1997). We therefore follow common practice to weight our observations based on the inverse of their probability of being included in the sample. We estimate robust variance estimates to obtain correct standard errors (Stata Press 2007).
} 
charge of production on these allocated plots and dispose of the income derived from them (Dolan 2001). The distribution of land and other productive resources depends on the bargaining power of the different household members (Udry 1996). Although we do not hold detailed information on decision processes for the intra-household resource allocation, we do observe which plots are managed by men and which plots are managed by women. We measure the effect of gender on market participation by including a dummy variable that takes on the value one if a woman is in charge of the finger millet plots. Female farmers often face higher marketing barriers than their male counterparts (Zeller et al. 1998; Quisumbing \& Pandolfelli 2010). We can thus expect a negative relationship between the gender dummy and market participation. On the other hand, traditional food crops are often considered female crops and are associated with comparably low transaction costs. Consequently, in the case of finger millet female producers may not be disadvantaged in terms of their market access.

Furthermore, we include a dummy variable that equals one if the household participates in a village group that is involved in finger millet activities. Group participation is expected to decrease transaction costs and thus to increase the probability of market participation. A major concern of using group membership as an independent variable is that it might be endogenous to market participation, i.e., group members may be systematically different from non-members in some unobserved characteristics that also influence their transaction costs associated with market participation.

As we will show in the next section, none of the farmers in our sample indicated that they joined a village group with the motive of improving their finger millet marketing possibilities. This gives us some confidence at least that group membership was not primarily driven by the desire to gain market access in the specific context of our study. To test for potential endogeneity of group membership in the market participation analysis, we also estimate an instrumental variable model using total farm size as an instrument for group membership. Farm size fulfills the formal criteria of 
instrument relevance (see weak identification and underidentification test results in section six). In principle, it may be argued that farm size also reduces the transaction costs of accessing millet markets. However, this argument is especially relevant in the context of high-value markets, when scale economies are important and producers have to deal with large-scale buyers. As our results in section six show, millet markets are relatively easily accessible also for poorer and more disadvantaged households. Hence, in our sample farm size is positively correlated with group membership $(p=0.007)$, but uncorrelated with participation in finger millet markets $(p=0.234)$. Last but not least, since we are interested in the gender-specific effects of collective action on market participation, we estimate a model specification including an interaction term between group membership and female responsibility for finger millet cultivation.

As further proxies for access to market information we include variables on the ownership of a cell phone and the ownership of a radio into the model. Information on agricultural commodity prices is radio broadcasted or available via text message services. Ownership of a cell phone furthermore facilitates communication with traders or other farmers. Transportation costs are influenced by market distance and available means of transport. Since finger millet is mainly marketed locally, we include the distance to the nearest village market. In addition, we add a dummy variable that equals one if the household owns a means of transport such as a cart, motorbike, or car. Finally, we include a dummy variable that equals one if the household sold maize in the market during 2011 . This variable is also used to capture the household's transaction costs and access to market information. Households who participate in maize marketing are likely to be better linked to cereal traders and have better access to information on cereal markets in general.

Again, some of these variables might be subject to reverse causality or simultaneity bias. In particular, it could be argued that marketing decisions for maize and millet are made simultaneously. Using an instrumental variables approach, we tested for potential endogeneity of maize marketing in 
the millet market participation model and could not reject the null hypothesis of exogeneity ${ }^{18}$. Similarly, owning a cell phone or a motorbike might be an outcome rather than a determinant of participation in millet markets. Unfortunately, we lack sufficient valid instruments to test whether exogeneity conditions are fulfilled for all of the asset-related variables. Similar variables related to means of transport or means of communication have been widely used in market participation analyses (Goetz 1992; Alene et al. 2008; Ouma et al. 2010). Results should, however, be interpreted with caution keeping potential endogeneity issues in mind.

Finally, the shadow price of finger millet plays an important role in the farmer's decision to sell finger millet in the market. For a household that produces finger millet for subsistence purposes, the shadow price is determined by its consumption needs. We therefore include household size as an independent variable in the model. Moreover, we include a number of variables related to household characteristics, namely age and education of the household head and a housing index that is used as a proxy for household wealth. The household index is composed of different properties of the dwelling, including the material of the walls, roof, and floor, the number of rooms, the availability of tap water, and electricity. As opposed to other wealth indicators, the characteristics of the dwelling are not changing in the short term and are therefore less likely to entail problems of endogeneity. To control for regional differences, we include dummy variables for the districts of Mumias and Teso, with Busia being the excluded category.

In the second model of our analysis, we assess the factors influencing the selling price obtained by farmers. The selling price is modeled using a linear OLS regression:

$$
P_{i}=Z_{i}^{\prime} \gamma+\varepsilon_{2 i}
$$

\footnotetext{
${ }^{18}$ We use maize yields as an instrument for maize market participation, which fulfills the criteria of instrument relevance according to the test statistics (weak identification (Kleibergen-Paap rk Wald $\mathrm{F}$ statistic): 25.359***, underidentification (Kleibergen-Paap rk LM statistic): $18.814 * * *)$. Maize yields are highly correlated with maize marketing $(p=0.000)$, but uncorrelated with millet market participation $(p=0.211)$. Full estimation results are provided by the authors on request.
} 
where $P_{i}$ represents the selling price obtained by farmer $i, Z$ is a vector of variables potentially influencing the selling price, $\gamma$ is a vector of parameters to be estimated, and $\varepsilon_{2}$ represents a normally distributed error term with mean zero and variance one.

The selling prices obtained by farmers for their produce are mainly influenced by their bargaining power. Through collective action small-scale farmers can pool their produce and thus increase their bargaining power vis-à-vis millet buyers. We therefore include a variable on finger millet group participation, which we expect to be positively related to the selling prices obtained. As in the market participation model, group membership may also be endogenous in the price regression, if unobserved systematic differences exist between group members and non-members that also influence their bargaining power in the market. Again, to test for potential endogeneity of group membership in the price regression, we estimate an instrumental variables model treating group membership as endogenous regressor and using the availability of millet extension in the village as an instrument for group membership. Village-level availability of millet extension fulfills the formal criteria of instrument relevance (see weak identification and underidentification test results in section six). In particular, millet related extension services train existing village groups in millet production activities, so that the likelihood of households to be part of a group involved in millet activities increases. One may also argue that this eventually may lead to price differences across villages, especially if millet markets are poorly integrated. However, there is no evidence for such price differences in our research area. While we find a strong correlation between village-level availability of millet extension and group membership $(p=0.000)$, there are no significant price differences between villages with and without millet extension $(p=0.806)$.

Since we are interested in gender-specific effects on price outcomes, we include a dummy variable that equals one if finger millet was sold by a female household member. Given traditional gender roles in western Kenya, we expect women to have less bargaining power than men vis-à-vis millet buyers. In addition, we expect that group membership is of particular importance for female sellers, 
who may be particularly disadvantaged in terms of their bargaining power when selling individually in the market. We therefore estimate a model specification that includes an interaction term between group membership and female seller.

We include additional variables on the ownership of a cell phone, the ownership of a radio and the distance to the nearest village market. These variables are expected to influence access to market and price information (see our arguments further above), and thereby also the farmer's bargaining power in millet markets. Similarly, we include the quantity of millet sold, as farmers selling larger quantities of millet are likely to have a better bargaining position. Furthermore, prices are likely to vary according to the selling season and the chosen market outlet. We control for these factors by including three dummy variables for different marketing seasons (with June - August 2011 being the excluded category) and four dummy variables for different market outlets (with selling to neighbors or extended family members being the excluded category). In particular, the market outlet is a choice variable that may be endogenous to the price outcome. As we do not have sufficient valid instruments to instrument for all possible market outlets, we estimate our model with and without the inclusion of the market outlet variables to explore in how far this affects the remaining parameter estimates of the model. Finally, the model includes household characteristics including the age and education level of the household head, as well as district dummies for Mumias and Teso. Table 3.1 provides summary statistics for the variables included in the econometric analyses. 
Table 3.1: Variables used in regression models

\begin{tabular}{|c|c|c|c|}
\hline Variable name & Variable description & Mean & Std. Dev. \\
\hline \multicolumn{4}{|c|}{ Household characteristics } \\
\hline Age head & age of the household head (in years) & 54.468 & 13.449 \\
\hline Education head & $1=$ household head has a secondary school education & .404 & .492 \\
\hline Household size & number of people in the household & 6.937 & 3.165 \\
\hline Housing index & $\begin{array}{l}\text { index of several housing variables (e.g. number of rooms } \\
\text { and construction materials) }\end{array}$ & .002 & .981 \\
\hline Female crop & 1 = finger millet was cultivated by a woman & .493 & .501 \\
\hline \multicolumn{4}{|l|}{ Market connectedness } \\
\hline Cell phone & $1=$ household owns a cell phone & .848 & .360 \\
\hline Radio & $1=$ household owns a radio & .815 & .389 \\
\hline Transport & $\begin{array}{l}1 \text { = household own a means of transportation (cart, } \\
\text { motorbike, car) }\end{array}$ & .137 & .345 \\
\hline Market distance & distance to next village market (in walking minutes) & 25.328 & 21.247 \\
\hline \multicolumn{4}{|l|}{ Marketing } \\
\hline Female seller & 1 = finger millet was sold by a woman & .400 & .491 \\
\hline Millet group & $\begin{array}{l}1 \text { = household participates in a village group that is } \\
\text { involved in finger millet activities }\end{array}$ & .441 & .497 \\
\hline Sold quantity & Quantity of finger millet sold in 2011 (in kg) & 132.978 & 331.779 \\
\hline Selling season 2 & 1 = Finger millet was sold in Sept. - Nov. & .333 & .472 \\
\hline Selling season 3 & 1 = Finger millet was sold in Dez. - Feb. & .289 & .454 \\
\hline Selling season 4 & 1 = Finger millet was sold in March - May & .015 & .121 \\
\hline Sold to trader & $1=$ Finger millet was sold to trader & .159 & .367 \\
\hline Sold to market & 1 = Finger millet was sold on the village market & .274 & .447 \\
\hline Sold to processor & $1=$ Finger millet was sold to processor & .044 & .206 \\
\hline Sold to institution & $1=$ Finger millet was sold to institution & .085 & .280 \\
\hline Maize marketing & $1=$ household sold maize in 2011 & .493 & .501 \\
\hline \multicolumn{4}{|l|}{ Location } \\
\hline Mumias & $1=$ household is situated in Butere-Mumias & .333 & .472 \\
\hline Teso & $1=$ household is situated in Teso & .400 & .491 \\
\hline \multicolumn{4}{|c|}{ Instrumental variables and interaction terms } \\
\hline Village with extension & $\begin{array}{l}1 \text { = household is located in a village where millet } \\
\text { extension is available }\end{array}$ & .800 & .401 \\
\hline Farm size & Farm size (in acres) & 3.973 & 3.978 \\
\hline Fecrop*group & Interaction term between female crop and millet group & .211 & .409 \\
\hline Feseller*group & interaction term between female seller and millet group & .226 & .419 \\
\hline
\end{tabular}

While the decision to market finger millet is observed for the whole sample, the selling price is only observed among those households who participate in the market. Since the marketing decision is not random but the result of marketing related transaction costs and opportunity costs, there might be systematic differences between market participants and non-participants that are unobserved and also influence bargaining power and thus price outcomes. Similar problems of selection bias 
have been addressed in previous market participation studies, e.g. by Goetz (1992) and Bellemare and Barrett (2006), who simultaneously estimated the discrete decision of market participation and the continuous decision of the transaction volume. Adopting a similar approach, we use a full information maximum likelihood (FIML) Heckman sample selection model to control for potential selection bias when estimating the price regression for market participants. The model assumes that the selling price $P_{i}$ is only observed when $X_{i}^{\prime} \beta+\varepsilon_{1 i}>0$ and the error terms $\varepsilon_{1}$ and $\varepsilon_{2}$ have a correlation $\rho$. If $\neq 0$, the null hypothesis of no selection bias cannot be rejected and the Heckman model results are preferred over simple OLS estimates.

Estimations of the Heckman sample selection model are more robust with an exclusion restriction, i.e., the inclusion of a variable that has an influence on the outcome of the first stage, but is uncorrelated with the error term in the second stage (Cameron \& Trivedi 2009). We use the variable maize marketing as exclusion restrictions, which is strongly correlated with the marketing of finger millet $(p=0.000)$, but unrelated to the selling price obtained for finger millet $(p=0.480)$.

\subsection{Descriptive Statistics}

The farmers in our sample are small-scale farmers who on average own four acres, of which 0.84 acres are planted with finger millet. Among the interviewed farmers, $64 \%$ sold finger millet or finger millet products in 2011. It is evident that finger millet is an important crop for female farmers: in $49 \%$ of the households, millet is grown under the sole responsibility of female household members and in $20 \%$ of the households both men and women are jointly responsible for millet cultivation. Furthermore, in $40 \%$ of the households women are involved in millet marketing.

Group membership in general is very common in rural Kenya and village organizations fulfill a variety of functions (Place et al. 2004). In our sample, we find different kinds of groups, including self-help groups, widow groups, religious groups, youth groups, and farmer groups. Typical group activities include savings and credit schemes, labor sharing, joint purchase of agricultural inputs, and financial assistance in the case of an emergency. Among the interviewed households in our sample, a large 
majority (86\%) participates in at least one group (see Table 3.2). This figure overestimates group membership in western Kenya due to our sampling design; however, we still find a high group membership rate of $76 \%$ if only considering those farmers who were not sampled as finger millet group members. Since agriculture plays a key role in the livelihoods of rural families, most groups are involved in agricultural activities, even if the group is not considered a farmer group in the first place. Overall, $44 \%$ of the households in our sample participate in a village group that is involved in finger millet activities. Most of them also had access to KARI extension through these groups (41\%). In the remainder of the article, we refer to groups that are involved in finger millet activities as 'finger millet groups'. However, it should be noted that all groups were originally formed as multipurpose village groups, and existed before the start of the millet extension program implemented by KARI in our research area. Regarding gender-specific group membership, $33 \%$ of the households in our sample have female members and $24 \%$ of the households have male members, who participate in finger millet groups ${ }^{19}$.

When asked about their motives to join a group, $75 \%$ of the farmers who participate in at least one group stated that they expected to obtain financial benefits such as access to credits, building up savings, and receiving financial assistance in the case of an emergency. Furthermore, $41 \%$ of the farmers aimed to improve their farming practices through better access to information, inputs, and extension. Only 16 farmers (7\%) specifically mentioned improved finger millet practices as a motive to join a group. Improved marketing possibilities were only mentioned by ten farmers (4\%), with eight of them referring to a specific product, but none of them referring to finger millet.

\footnotetext{
${ }^{19}$ In $13 \%$ of the households we find both male and female members participating in finger millet groups.
} 
Table 3.2: Participation in village groups

\begin{tabular}{lrr} 
& Frequency & Percentage \\
\hline Participation in at least one village group & 232 & 85.93 \\
Participation in a group involved in finger millet activities & 119 & 44.07 \\
Female group member & 88 & 32.59 \\
Male group member & 65 & 24.07 \\
Participation in a group involved in finger millet activities and with & 112 & 41.48 \\
access to KARI extension & & \\
\hline
\end{tabular}

Farmers in our sample received an average selling price of 55 KES per kg of finger millet, which is very close to the average market price of finger millet in Kenya in 2011 as indicated by the Kenyan Agricultural Commodity Exchange (see section two). Among the farmers who market finger millet, $19 \%$ sell to neighbors or family within the village, $45 \%$ sell their produce at the village market, $26 \%$ sell to a local trader, $14 \%$ sell to an institution such as an orphanage or a school, and $7 \%$ sell to a local processor. Table 3.3 compares average prices received in these different market outlets and reveals that they do not vary significantly. In contrast, we can see that membership in finger millet groups is associated with higher prices: group members receive $58 \mathrm{KES}$ per $\mathrm{kg}$, while non-group members receive only 51 KES per kg, on the average. Although in our research area group leadership is usually male, we have four finger millet groups with female group leaders in our sample. Yet, in contrast to the findings from Barham and Chitemi (2009), we do not find a significant difference in selling prices between groups with female and groups with male leadership. Overall, we do not observe a significant difference in the prices obtained by male and female sellers. However, when we restrict our sample to households selling individually, i.e., households who do not participate in a finger millet group, we find that female sellers receive significantly lower prices. 
Table 3.3: Selling prices

\begin{tabular}{lll} 
& \multicolumn{2}{l}{ Selling price of finger millet (in KES) } \\
\cline { 2 - 3 } & & \\
\hline Gender and group participation & $50.95(16.82)$ & \\
\hline Finger millet group & $57.63(16.16)$ & $58.02(17.53)^{* * *}$ \\
Female group leadership & $56.95(12.46)$ & $58.80(20.25)$ \\
Female seller & $56.80(16.09)$ & $54.30(19.72)$ \\
Female seller (non-group members) & $55.23(17.94)$ & $48.71(16.72)^{* *}$ \\
\hline Marketing channel & $55.52(15.16)$ & $55.18(16.08)$ \\
\hline Selling to neighbors / family & $55.38(18.31)$ & $54.86(20.17)$ \\
Selling on market & $55.33(17.81)$ & $54.74(15.29)$ \\
Selling to trader & $54.57(17.49)$ & $53.85(14.34)$ \\
Selling to processor & & $59.42(17.77)$ \\
Selling to institution & & \\
\hline All variables were tested using t-tests & & \\
Values in brackets are standard deviations & & \\
$*, * *$, and $* * *$ & indicate that the mean difference is significant on a 10\%, 5\%, and $1 \%$ significance level, \\
respectively & & \\
\hline
\end{tabular}

\subsection{Econometric results}

Results on the determinants of market participation are presented in Table 3.4. Three model specifications are shown: Model I represents a probit model with market participation as the dependent variable. Model II employs an instrumental variables estimator controlling for potential endogeneity of group membership. Finally, we estimate a probit model including an interaction term between female crop and group membership (Model III).

Considering Model I, we find that ceteris paribus the probability to market finger millet is 7.4 percentage points higher for households in which a female member is responsible for finger millet production. Since the person who crops is mostly the person who sells, this indicates that women do not face particular barriers to enter the finger millet market ${ }^{20}$. In line with this finding, the housing index has a negative effect on market participation, indicating that poorer households are more likely to participate in finger millet marketing. These results are consistent with the hypothesis that poorer and more disadvantaged farmers, who are often excluded from more remunerative high-

\footnotetext{
${ }^{20}$ When finger millet is cultivated by a woman, it is also sold by a woman in $92 \%$ of the cases.
} 
value markets and off-farm activities, face lower opportunity costs to engage in finger millet marketing.

Furthermore, participation in a finger millet group increases the probability of marketing finger millet by 6.7 percentage points. Similarly, farmers who are sellers of maize are also more likely to participate in the finger millet market. These findings indicate that networks and market linkages are important determinants of participation in finger millet markets. On the other hand, typical variables related to market and information access such as ownership of a cell phone or radio, means of transport or market distance are not significantly associated with marketing of finger millet in our analysis.

The results from the instrumental variable model (Model II) confirm these findings. Group membership, which is treated as an endogenous regressor in this model, remains significant and positive. According to the results of a Kleibergen-Paap rk LM test ${ }^{21}$ we can reject the hypothesis that the model is underidentified. In addition, we obtain the Kleibergen-Paap rk Wald statistic to test for weak identification (Baum et al. 2007). The value of 11.398 confirms the relevance of the chosen instrument. Finally, testing for endogeneity, the null hypothesis that group membership is exogeneous cannot be rejected at the 99 percent significance level.

In Model III we include an interaction term between gender and group membership to investigate their relationship more closely. We find that group membership for both male and female producers has a positive and statistically significant effect on market participation (the joint significance test for group membership and the interaction term is significant at the one percent probability of error). The insignificant interaction term illustrates that there is no significant difference between male and female producers regarding the effect of group membership on millet market participation. On the other hand, the gender variable turns insignificant. While these results do not confirm better access

\footnotetext{
${ }^{21}$ According to Baum et al. (2007), the Kleibergen-Paap rk statistic is appropriate when robust standard errors are estimated. The Wald version of the rk statistic is equivalent to the Cragg-Donald statistic and the LM version of the rk statistic is equivalent to the Anderson canonical correlation rank statistic when standard errors are i.i.d.
} 
of women to millet markets, they are consistent with the notion that women are not excluded from these markets either.

Table 3.4: Market participation

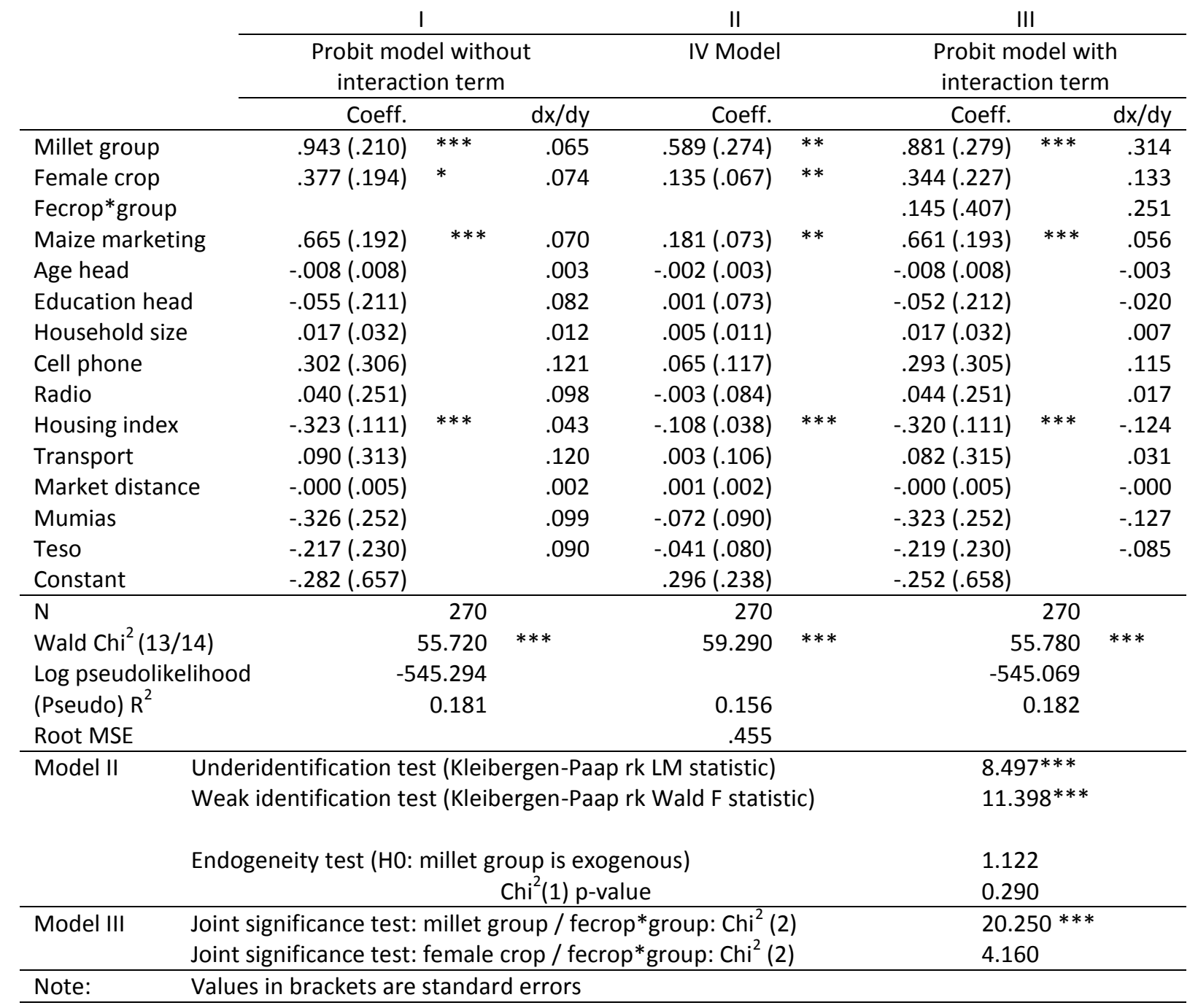

Table 3.5 shows results from five different model specifications estimating the determinants of the selling price. Results from a simple OLS regression on prices (Model I) reveal that group membership is associated with an increase in selling prices of 7 KES. Furthermore, the ownership of a cell phone is associated with a price increase of 9 KES. Finally, farmers located in Mumias obtain significantly higher selling prices than farmers located in Busia. While these results reveal some interesting correlations they need to be treated with caution, as some of the included regressors may be subject to endogeneity bias. 
Model I includes four variables related to different marketing channels, which may potentially be endogenous and thereby bias all other coefficients in the model. For lack of sufficient valid instruments, we re-estimate the OLS model excluding the respective marketing channel related variables from the right-hand-side of the model (Model II). As can be seen in Table 3.5, the parameter estimates for the other explanatory variables remain essentially unaffected by the exclusion of the market channel related variables.

Next, we estimate an instrumental variable model instrumenting for group membership (Model III). Again, the test statistics indicate that the chosen instrument is not weak (Kleibergen-Paap rk Wald $F$ statistic: 16.852) and that the model is not underidentified. Yet, the coefficient on group membership turns insignificant and we cannot reject the null hypothesis of exogeneity. All other results remain largely consistent with the OLS estimation.

As discussed in the methodology section, market participants may differ systematically from nonparticipants in terms of unobserved characteristics that also influence their bargaining power (and thereby the selling price). In Model IV, we therefore estimate a Heckman selection model to control for potential selection bias affecting the sub-sample of market participants included in the price regression. As can be seen in Table 3.5, the estimates from the second stage price regression are consistent with the parameter estimates from the OLS regression ${ }^{22}$. Based on a Wald test of independent equations, however, we cannot reject the null hypothesis that $\rho=0$, indicating that selection bias does not adversely affect our estimation results.

For the most part, model results so far provide evidence that collective action is positively associated with selling prices obtained by farmers. In Model $V$ we include an interaction term between group membership and female seller to investigate potential gender-specific effects of collective action on prices. First and foremost, we can see that the coefficient on female seller is negative and significant

\footnotetext{
${ }^{22}$ First-stage results of the Heckman selection model are provided in Annex A (Table A.1).
} 
indicating that female sellers who market individually obtain significantly lower prices compared to individually selling men. Furthermore, the coefficient on group membership reveals that male sellers do not significantly increase their prices through collective action. Yet, the interaction term between group membership and female seller is significant indicating that women can increase their prices through collective action. Overall, for female sellers group membership leads to a price increase of 10.493 KES (the joint significance test for group membership and the interaction term is significant at the one percent probability of error). 
Table 3.5: Selling prices

\begin{tabular}{|c|c|c|c|c|c|c|c|c|c|c|}
\hline & \multicolumn{2}{|l|}{1} & \multicolumn{2}{|l|}{ II } & \multicolumn{2}{|l|}{ III } & \multicolumn{2}{|l|}{ IV } & \multicolumn{2}{|l|}{ V } \\
\hline & \multicolumn{2}{|c|}{ OLS Regression } & \multicolumn{2}{|c|}{ OLS Regression } & \multicolumn{2}{|c|}{ IV model } & \multicolumn{2}{|c|}{$\begin{array}{c}\text { Heckman } \\
\text { model }\end{array}$} & \multicolumn{2}{|c|}{$\begin{array}{c}\text { OLS } \\
\text { regression }\end{array}$} \\
\hline & Coeff. & & Coeff. & & Coeff. & & Coeff. & & Coeff. & \\
\hline Millet group & 7.390 & $* * *$ & 7.441 & $* * *$ & -5.678 & & 5.837 & $*$ & .385 & \\
\hline & (2.821) & & (2.697) & & (11.556) & & (3.199) & & (3.993) & \\
\hline Female seller & $\begin{array}{r}-3.327 \\
(2.655)\end{array}$ & & $\begin{array}{r}-3.244 \\
(2.548)\end{array}$ & & $\begin{array}{l}-3.186 \\
(2.604)\end{array}$ & & $\begin{array}{l}-3.471 \\
(2.492)\end{array}$ & & $\begin{array}{l}-8.229 \\
(3.679)\end{array}$ & $* *$ \\
\hline Feseller* group & & & & & & & & & $\begin{array}{l}10.108 \\
(4.971)\end{array}$ & $* *$ \\
\hline Age head & $\begin{array}{r}.121 \\
(.106)\end{array}$ & & $\begin{array}{r}.129 \\
(.098)\end{array}$ & & $\begin{array}{r}.095 \\
(.110)\end{array}$ & & $\begin{array}{r}.135 \\
(.103)\end{array}$ & & $\begin{array}{r}.109 \\
(.103)\end{array}$ & \\
\hline Education head & $\begin{array}{r}-4.154 \\
(3.028)\end{array}$ & & $\begin{array}{r}-3.916 \\
(2.914)\end{array}$ & & $\begin{array}{r}-4.181 \\
(3.103)\end{array}$ & & $\begin{array}{r}-3.985 \\
(2.913)\end{array}$ & & $\begin{array}{r}-3.911 \\
(2.959)\end{array}$ & \\
\hline Cell phone & $\begin{array}{r}9.221 \\
(5.142)\end{array}$ & $*$ & $\begin{array}{r}9.084 \\
(4.677)\end{array}$ & $*$ & $\begin{array}{l}10.748 \\
(4.585)\end{array}$ & $* *$ & $\begin{array}{r}8.865 \\
(4.829)\end{array}$ & $*$ & $\begin{array}{r}8.742 \\
(5.280)\end{array}$ & $*$ \\
\hline Radio & $\begin{array}{r}-2.243 \\
(4.957)\end{array}$ & & $\begin{array}{r}-1.911 \\
(4.513)\end{array}$ & & $\begin{array}{r}-1.402 \\
(4.974)\end{array}$ & & $\begin{array}{r}-2.034 \\
(4.706)\end{array}$ & & $\begin{array}{r}-2.587 \\
(5.055)\end{array}$ & \\
\hline Mumias & $\begin{array}{l}13.045 \\
(5.140)\end{array}$ & $* *$ & $\begin{array}{l}12.660 \\
(4.698)\end{array}$ & $* * *$ & $\begin{array}{l}12.169 \\
(5.163)\end{array}$ & $* *$ & $\begin{array}{l}13.902 \\
(5.028)\end{array}$ & $* * *$ & $\begin{array}{l}13.741 \\
(5.076)\end{array}$ & $* * *$ \\
\hline Teso & $\begin{array}{r}-3.356 \\
(2.783)\end{array}$ & & $\begin{array}{r}-3.323 \\
(2.691)\end{array}$ & & $\begin{array}{r}-4.630 \\
(3.075)\end{array}$ & & $\begin{array}{r}-3.148 \\
(2.703)\end{array}$ & & $\begin{array}{r}-2.840 \\
(2.761)\end{array}$ & \\
\hline Market distance & $\begin{array}{l}.0531 \\
(.051)\end{array}$ & & $\begin{array}{r}.057 \\
(.050)\end{array}$ & & $\begin{array}{r}.034 \\
(.063)\end{array}$ & & $\begin{array}{r}.049 \\
(.049)\end{array}$ & & $\begin{array}{r}.054 \\
(.050)\end{array}$ & \\
\hline Selling season 2 & $\begin{array}{r}-2.351 \\
(4.670)\end{array}$ & & $\begin{array}{r}-2.056 \\
(4.755)\end{array}$ & & $\begin{array}{r}-.576 \\
(4.883)\end{array}$ & & $\begin{array}{l}-2.081 \\
(4.475)\end{array}$ & & $\begin{array}{r}-1.915 \\
(4.574)\end{array}$ & \\
\hline Selling season 3 & $\begin{array}{r}-.225 \\
(4.421)\end{array}$ & & $\begin{array}{r}-.080 \\
(4.462)\end{array}$ & & $\begin{array}{r}.258 \\
(4.507)\end{array}$ & & $\begin{array}{r}.2177 \\
(4.286)\end{array}$ & & $\begin{array}{r}-.658 \\
(4.349)\end{array}$ & \\
\hline Selling season 4 & $\begin{array}{r}-4.395 \\
(4.720)\end{array}$ & & $\begin{array}{r}-4.168 \\
(5.005)\end{array}$ & & $\begin{array}{r}-4.131 \\
(6.015)\end{array}$ & & $\begin{array}{r}-4.220 \\
(4.469)\end{array}$ & & $\begin{array}{r}-6.334 \\
(5.534)\end{array}$ & \\
\hline Sell to trader & $\begin{array}{r}1.438 \\
(4.048)\end{array}$ & & & & $\begin{array}{r}2.111 \\
(4.242)\end{array}$ & & $\begin{array}{r}1.358 \\
(3.842)\end{array}$ & & $\begin{array}{r}1.765 \\
(3.964)\end{array}$ & \\
\hline Sell to market & $\begin{array}{r}.115 \\
(4.146)\end{array}$ & & & & $\begin{array}{r}1.009 \\
(4.215)\end{array}$ & & $\begin{array}{r}.059 \\
(3.911)\end{array}$ & & $\begin{array}{r}-.077 \\
(4.119)\end{array}$ & \\
\hline Sell to processor & $\begin{array}{r}-3.658 \\
(3.952)\end{array}$ & & & & $\begin{array}{r}-1.947 \\
(4.939)\end{array}$ & & $\begin{array}{r}-3.534 \\
(3.745)\end{array}$ & & $\begin{array}{r}-3.375 \\
(3.692)\end{array}$ & \\
\hline Sell to institution & $\begin{array}{r}2.386 \\
(5.823)\end{array}$ & & & & $\begin{array}{r}6.281 \\
(6.620)\end{array}$ & & $\begin{array}{r}2.238 \\
(5.562)\end{array}$ & & $\begin{array}{r}2.617 \\
(5.908)\end{array}$ & \\
\hline Selling quantity & $\begin{array}{r}-.005 \\
(.004)\end{array}$ & & $\begin{array}{r}-.004 \\
(.003)\end{array}$ & & $\begin{array}{r}-.000 \\
(.006)\end{array}$ & & $\begin{array}{r}-.005 \\
(.004)\end{array}$ & & $\begin{array}{r}-.006 \\
(.004)\end{array}$ & \\
\hline Constant & $\begin{array}{l}39.781 \\
(8.589) \\
\end{array}$ & $* * *$ & $\begin{array}{r}39.000 \\
(7.725) \\
\end{array}$ & $* * *$ & $\begin{array}{l}43.071 \\
(8.730) \\
\end{array}$ & $* * *$ & $\begin{array}{r}41.238 \\
(8.088) \\
\end{array}$ & $* * *$ & $\begin{array}{r}44.249 \\
(8.761) \\
\end{array}$ & $* * *$ \\
\hline $\mathrm{N}$ & 164 & & 164 & & 164 & & 262 & & 164 & \\
\hline $\mathrm{F}$ & 4.000 & $* * *$ & 4.760 & $* * *$ & & & & & 3.920 & $* * *$ \\
\hline $\begin{array}{l}\text { Wald } \mathrm{Chi}^{2} \\
\mathrm{R}^{2}\end{array}$ & 0.238 & & 0.233 & & $\begin{array}{r}50.440 \\
0.119\end{array}$ & $* * *$ & 74.09 & $* * *$ & 0.255 & \\
\hline Root MSE & 15.902 & & 15.745 & & 16.132 & & & & 15.782 & \\
\hline
\end{tabular}


Table 3.5 (continued)

\begin{tabular}{|c|c|c|}
\hline Model III & $\begin{array}{l}\text { Underidentification test (Kleibergen-Paap rk LM statistic) } \\
\text { Weak identification test (Kleibergen-Paap rk Wald F statistic) }\end{array}$ & $\begin{array}{l}11.808^{* * *} \\
16.852^{* * *}\end{array}$ \\
\hline & $\begin{array}{l}\text { Endogeneity test (HO: millet group is exogenous) } \\
\qquad \mathrm{Chi}^{2}(1) \mathrm{p} \text {-value }\end{array}$ & $\begin{array}{l}1.383 \\
0.240\end{array}$ \\
\hline Model IV & $\begin{array}{l}\text { Log pseudo-likelihood } \\
\text { Wald test of indep. eqns. (rho =0) } \\
\qquad \text { Chi }^{2}(1) \text { p-value }\end{array}$ & $\begin{array}{l}-2679.650 \\
0.540 \\
0.461\end{array}$ \\
\hline Model V & $\begin{array}{l}\text { Joint significance test: female seller / feseller*group: } F(2,145) \\
\text { Joint significance test: millet group / feseller*group: } F(2,145)\end{array}$ & $\begin{array}{l}2.670^{*} \\
4.5800^{* *}\end{array}$ \\
\hline Note: & Values in brackets are standard errors & \\
\hline
\end{tabular}

Altogether, results from our analyses indicate that market access per se is not restricted to advantaged and better-off households. While disadvantaged farmers, including the poor as well as female farmers, are often found to be excluded from high-value agricultural markets, this does not seem to be the case for traditional food markets such as finger millet. On the contrary, marketing finger millet in our research area tends to be more common among female producers and less endowed households. However, group participation is an important factor facilitating market participation and higher selling prices. In particular, we find that collective action is important for female sellers, who experience a disadvantage in the millet market in terms of lower prices unless they are organized in millet groups.

\subsection{Conclusions}

A shift from subsistence agriculture to more specialized and commercialized production systems is considered to be a key factor for the alleviation of poverty and food insecurity among smallholder farmers in developing countries. However, especially the least endowed farmers are often found to be excluded from remunerative markets due to high transaction costs, e.g. in the form of standard requirements, transportation costs, or market risks. While female income has been shown to contribute more to the household's food security than male income, women often face even higher market barriers than their male counterparts. The marketing of food grains might be a viable alternative especially for those farmers who are excluded from high-value markets. Compared to 
high-value crops, producing and marketing food grains entails a lower income potential, but also lower market barriers in terms of market risks and other transaction costs. We add to the scant literature on traditional food grain marketing by analyzing the marketing decisions of finger millet farmers in western Kenya.

Overall, coordination along the finger millet value chain in western Kenya is rather weak. While traders and processors do not find sufficient quantities of finger millet for their operations, producers lack knowledge about suitable buyers to sell in larger quantities. Selling prices vary greatly and finger millet traders earn higher margins from finger millet than from trading other food grains. Although price information services exist, they are not widely used by farmers.

Our main interest lies in the effect of gender and collective action on the household's marketing decision and selling prices. The econometric analyses presented in this article show that female producers and less endowed farmers are not excluded from millet markets. On the other hand, there is evidence that female sellers tend to receive lower selling prices than male sellers unless they participate in finger millet groups. While participation in millet groups is positively associated with selling prices for female sellers, it does not have a significant influence on the selling prices obtained by male sellers. The importance of collective action for women's marketing performance needs to be seen in the cultural and social context of western Kenya. Traditional gender roles assign women the responsibility for subsistence food production, whereas cash crop production is in the domain of men. Traditional female gender roles are thus often associated with lower bargaining power in market transactions, as reflected by the lower prices obtained by individually selling women in our sample. In this context, producer groups can support women to gain and sustain their position in the market. This support is often facilitated through extension agents, who not only provide women with training and technical support, but also link them to potential buyers in the market. After all, it is possible that through this "collective empowerment" women also improve their bargaining power within the household and thus achieve a more favorable allocation of productive resources for 
themselves. This is of course beyond the analysis presented in this article, but provides an interesting starting point for further, more interdisciplinary research.

A number of policy implications follow from our results. Improving market coordination represents an important step towards increasing the incomes of small-scale farmers from millet marketing. Information on existing services that provide market information and link farmers with buyers should be disseminated more widely and adjusted to the needs of small-scale farmers and traders. Enhancing information flows along the value chain is essential to increase the efficiency of millet markets and decrease the currently high trader margins. Furthermore, specialized extension services can help farmer groups to link to larger buyers and enable them to provide finger millet of sufficient quantity and quality. Collective action is a key factor to empower female sellers and improve their bargaining position in the market. Training of farmer groups should therefore include gender aspects to ensure that female group members are not marginalized in the often male dominated farmer groups. Furthermore, women groups should receive special attention from policy makers to guarantee equal opportunities for those groups and their members. 


\section{Part four}

\section{Technical efficiency and profitability of traditional food crop production in Sub-Saharan Africa}

In Sub-Saharan Africa, traditional food crops such as millets have been gradually replaced by main food crops such as maize over the past century. While main food crops offer advantages, especially in terms of yields, traditional food crops play an important role in assuring micronutrient supply and the resilience of agricultural production systems. The potential of traditional food crops can only be exploited if these crops represent a profitable cropping choice for small-scale farmers. Technically efficient production systems are a key precondition for a profitable production. While there is a substantial amount of literature assessing technical efficiency and profitability of different crops or cropping systems, little attention has been given to traditional food crops. Based on household data from 270 finger millet households in western Kenya, the present study adds to the scarce literature on traditional food crops by analyzing (a) technical efficiency in finger millet production, (b) the factors that influence technical efficiency, and (c) the profitability of finger millet production. All analyses are conducted in comparison to maize production. Results show that both technical efficiency and profitability are higher in maize than in finger millet production. In the case of finger millet, female farmers obtain lower levels of technical efficiency and lower profits, while participation in village groups has a positive effect on technical efficiency. 


\subsection{Introduction}

Africa has experienced a steady decline of traditional food crop production over the past century. Indigenous cereals, roots, and tubers were gradually replaced by "the big three" (maize, wheat, and rice) and have received little attention by policy makers and researchers in the past decades (Kennedy \& Reardon 1994). While the big three offer a high yield potential and serve as main staple crops for a large part of the world's population, their potential is limited in terms of micronutrient supply and adaptability to unfavorable agro-ecological conditions (National Research Council 1996). Traditional food crops offer valuable traits such as fast maturity (e.g. fonio, sorghum), heat and drought resistance (e.g. pearl millet, cassava), or high contents of essential proteins and micronutrients (e.g. finger millet, tef) (Pearce 1990; National Research Council 1996). Against the background of climate change, extensive soil erosion, and a high prevalence of micronutrient deficiencies in developing countries, traditional food crops make an important contribution to food security in many developing countries. Despite that, the area dedicated to traditional food crops keeps declining in many regions of Sub-Saharan Africa (National Research Council 1996; Crowley \& Carter 2000).

In order to be an attractive cropping option for small-scale farmers, traditional food crops need to be more than locally adapted and rich in micronutrients. A crucial factor for the decision to continue or recommence the cultivation of a traditional food crop is its profitability in comparison to main staple crops. Besides other factors such as market access and the genetic potential of the cultivated crop, an efficient use of the given productive resources is essential to achieve profitability. While numerous studies in the context of small-scale agriculture focus on profitability (Rourke 1974; Boateng et al. 1987; Lukanu et al. 2009) and technical efficiency (Kaliba 2004; Goyal et al. 2006; Backman et al. 2011; Rao et al. 2012; Wollni \& Brümmer 2012) in their analysis, traditional food crops have received little attention by researchers so far. 
The present paper aims to fill this research gap by analyzing the profitability and efficiency of a traditional food crop - finger millet - in western Kenya. Based on household data from 270 finger millet producers, we assess (a) the technical efficiency with which finger millet is produced, (b) the factors that influence technical efficiency, and (c) the per acre profitability of finger millet. While finger millet is only grown by a minority of farmers in western Kenya, almost every farm household in the research area produces maize. To compare finger millet with the main staple crop of the region, we conduct the same analyses for maize production. Since food crops and in particular traditional food crops are often considered a female domain, we put a special focus on gender in our analysis. The remainder of the paper is organized as follows. Section two discusses the issues of profitability and efficiency in the context of small-scale agriculture in developing countries. Section three provides a brief overview of the research area and our data collection approach. Section four summarizes basic descriptive statistics of our sample. The methodology and results of the technical efficiency analysis are presented in section five. A comparison of profitability in finger millet and maize production is given in section six. Finally, we draw conclusions and policy recommendations from our analysis in section seven.

\subsection{Profitability and efficiency in agricultural production systems}

Profitability comparisons between modern crops and traditional crops have been conducted by a number of studies with mixed results. For example, Boateng et al. (1987) and Rourke (1974) compare the profitability of cocoa and traditional cropping systems in Ghana. While Boateng et al. conclude that traditional food crops are more profitable, Rourke finds that cocoa production has a similar profitability as traditional cropping systems, especially if intercrops in the production of cocoa are taken into account. A more recent study by Lukanu (2009) in Mozambique finds most nonfood cash crops to be more profitable than food cash crops. Achieving profitability in traditional food crop production is of particular importance for small-scale farmers, since these farmers are often excluded from high-value agricultural markets (Maertens \& Swinnen 2009; Handschuch et al. 2013). 
Likewise, profitability in the production of traditional food crops is of particular importance for female farmers, who often face even higher barriers in accessing high-value markets (Dolan 2001; Njuki et al. 2011). Traditional food crops are often considered to be "female crops" that are mainly grown by women. Although the categorization of crops into "female crops" and "male crops" is debatable (Doss 2002) women undoubtedly play a very important role in the production and marketing of traditional food crops. The importance of female incomes for food security has been underlined by several studies that find a significantly stronger effect of female incomes than of male incomes on household food security (Hoddinott \& Haddad 1995; Fischer \& Qaim 2012a). At the same time, it is often found that women obtain lower levels of profitability because of higher barriers to access in- and output markets as well as farm productive resources such as high quality land (Zeller et al. 1998; Quisumbing \& Pandolfelli 2010; Croppenstedt et al. 2013; Kilic et al. 2013).

While it is relatively simple to assess the profitability of crops and cropping systems, identifying the causes for different levels of profitability is not as straightforward. Besides factors such as agroecological conditions, the genetic potential of the cultivated crop, and access to productive resources, the technical efficiency in the production process influences profitability and can vary substantially across different farms and cropping systems. Since Schultz (1964) posed his "poor but efficient" hypothesis, there has been an ongoing debate on whether or not small-scale farmers in developing countries are producing efficiently within their given resource constraints (Abler \& Sukhatme 2006). An extensive strand of literature is analyzing technical efficiency in the farming sector of developing countries. Most studies find ample scope for production increases at given levels of inputs. For example, Kaliba (2004) and Tchakounte (2012) find efficiency levels of around $60 \%$ in the Tanzanian dairy production and the Cameroonian cotton sector, respectively. Apart from low levels of average technical efficiency, many studies also observe a high variability of efficiency estimates across farms (Goyal et al. 2006; Backman et al. 2011), a finding that underlines the importance of identifying the factors that influence technical efficiency. Previous research has 
identified factors such as market access, group membership, education, and age as factors that influence technical efficiency (Phillips \& Marble 1986; Bravo-Ureta \& Pinheiro 1997; Binam et al. 2003; 2004; Rao et al. 2012; Wollni \& Brümmer 2012). Although female farmers are often found to obtain lower levels of profitability than male farmers (Croppenstedt et al. 2013; Kilic et al. 2013), it remains unclear whether female farmers produce at lower levels of technical efficiency than their male counterparts. A review of existing literature by Quisumbing (1996) reveals that most studies do not find significant differences in the efficiency of female and male farmers. However, Quisumbing also states that many studies suffer from methodological shortcoming and that evidence on gender differences in farm efficiency therefore remains inconclusive.

\subsection{Research area and data collection}

As in most parts of Sub-Saharan Africa, a large share of the Kenyan population relies on agricultural activities for their livelihoods. In terms of food crops, maize is by far the country's most important crop and was cultivated on 2.16 Mio hectares in 2012. At the same time, millets ${ }^{23}$ were only cultivated on 0.11 Mio hectares, sorghum on 0.24 Mio hectares, and other cereals on 0.20 Mio hectares. Other starchy staple food such as cassava, yams, and potatoes were cultivated on 0.28 Mio hectares (FAO 2013). Finger millet is mainly grown in western Kenya, where it used to be one of the main staple foods until the 1930s (Crowley \& Carter 2000).

Western Kenya is a high potential agricultural production area with two cropping seasons per year ${ }^{24}$. However, the region suffers from high population pressure, which has resulted in unsustainable agricultural intensification and severe problems of soil erosion. In combination with increasingly erratic rainfall patterns, this development has led to stagnating or even declining maize yields in the region (Crowley \& Carter 2000). Moreover, the heavily maize based diet of most people in western Kenya has led to a high prevalence of protein and micronutrient deficiencies (Conelly \& Chaiken

\footnotetext{
${ }^{23}$ FAO statistics do not differentiate between different types of millet.

${ }^{24}$ The long-rains (approx. from February to July) and the short-rains (approx. from October to December)
} 
2000). While finger millet has been widely neglected by researchers and policy makers throughout the $20^{\text {th }}$ century, it has recently received some attention for its good adaptability to unfavorable agro-ecological conditions, its nutritious value, and the currently high market prices (Oduori 2005). Our empirical analysis is based on a farm household survey that was conducted in Western Province in 2011. Using a standardized household questionnaire, we interviewed 270 finger millet producers in the districts of Busia, Mumias, and Teso ${ }^{25}$. The three districts had been the target area of a finger millet extension program provided by the Kenyan Agricultural Research Institute (KARI). To reach the farmers, KARI approached village groups with a high share of finger millet producers and provided extension on improved cropping practices to the group members. We include farmers with and without access to KARI extension into our sample by using a stratified random sampling approach. In a first step, we randomly selected 12 out of 32 KARI extension locations and 3 non-KARI extension locations. In a second step, we randomly selected 9 members of a group with access to KARI extension and 9 non-group members in each of the KARI extension locations. In the locations without KARI extension, we randomly selected 18 finger millet farmers. All production and income data refers to 2011. Lists of farmers who cultivated finger millet in 2011 were provided by village elders and group leaders. We account for the oversampling of farmers with access to KARI extension by using sampling weights in the econometric analysis.

\subsection{Descriptive statistics}

In the long-rain season 2011, all of the 270 interviewed households grew finger millet and 254 households grew maize. While finger millet is only grown during the long-rains, maize is grown in both cropping seasons. However, to ensure comparability of the finger millet and maize production data, we exclusively rely on long-rain data in our empirical analysis. During the long rain season

\footnotetext{
${ }^{25}$ The boundaries and names of administrative areas often changed in the recent past. E.g., provinces no longer exist and districts were converted into counties with the commencement of the new constitution in 2013 (TISA 2013). For reasons of simplicity, our article refers to the district and province boundaries that existed prior to the 2007 district reform.
} 
2011, an average area of 0.84 acres and 1.32 acres was dedicated to finger millet and maize production, respectively ${ }^{26}$. Finger millet production was under the sole responsibility of a woman in $49 \%$ of the households, while either a male household member or a team of female and male household members was responsible for finger millet production in $51 \%$ of the households. In the case of maize, the production was under the sole responsibility of a woman in $44 \%$ of the households. These figures underline the finding by Doss (2002) that a differentiation between "female" and "male" crops is often misleading. However, when looking at female and male farm incomes, we do find that women rely to a large extent on the marketing of staple crops to generate their income, while men derive a higher share of their incomes from the marketing of cash crops. Table 4.1 shows that finger millet, maize, and other staple crops together account for $63 \%$ of total female farm incomes, but only for $34 \%$ of total male farm incomes. On the other hand, cash crops account for $15 \%$ of male farm incomes, but for less than $2 \%$ of female farm incomes Our data supports findings from existing literature that female farmers have less access to cash crop markets and therefore need to rely on the income from staple foods to a larger extent (Dolan 2001; Njuki et al. 2011).

Table 4.1: Composition of female and male farm incomes

\begin{tabular}{lcccrrr} 
& \multicolumn{2}{c}{$\begin{array}{c}\text { Share of female farm } \\
\text { incomes }\end{array}$} & $\begin{array}{c}\text { Share of male farm } \\
\text { incomes }\end{array}$ & \multicolumn{2}{c}{$\begin{array}{c}\text { Share of total farm } \\
\text { incomes }\end{array}$} \\
\cline { 2 - 7 } & Mean & Std. Dev. & Mean & Std. Dev. & Mean & Std. Dev. \\
\hline Finger millet & .28 & .36 & .11 & .24 & .23 & .30 \\
Maize & .21 & .32 & .16 & .29 & .20 & .28 \\
Other staple crops ${ }^{2}$ & .13 & .25 & .07 & .18 & .10 & .19 \\
Cash crops & .02 & .11 & .15 & .33 & .08 & .23 \\
Vegetables & .03 & .14 & .03 & .15 & .03 & .12 \\
Fruits & .06 & .21 & .06 & .21 & .05 & .15 \\
Livestock & .27 & .38 & .41 & .43 & .28 & .34 \\
\hline${ }^{a}$ Other staple crops include other cereals, roots, tubers, groundnuts, and pulses. Cash crops include tobacco, \\
cotton, and sugarcane. Livestock income is generated from the sales of animals or their products. \\
\hline
\end{tabular}

Regarding the production process, finger millet is less demanding in terms of nutrient supply, but requires more labor input than maize and has a lower yield potential (Mgonja et al. 2007). These

\footnotetext{
${ }^{26}$ The average farm size in our sample is 3.97 acres.
} 
differences between finger millet and maize production are reflected in our production data (see Table 4.2). On average, a farmer uses $25 \mathrm{~kg}$ of chemical fertilizer and 131 man-days of labor per acre of finger millet. In maize production, an average of $33 \mathrm{~kg}$ of chemical fertilizer and 86 man-days of labor are used per acre. Our production data furthermore reflects the generally lower yield potential of finger millet: The average maize yield of $603 \mathrm{~kg}$ per acre is almost twice as high as the average finger millet yield of $328 \mathrm{~kg}$ per acre.

Table 4.2: Input and yield differences between male and female producers

\begin{tabular}{|c|c|c|c|c|c|c|c|}
\hline & \multicolumn{2}{|c|}{ Female crop } & \multicolumn{2}{|c|}{ Male crop } & \multicolumn{2}{|c|}{ Total } & \\
\hline & Mean & Std. Dev. & Mean & Std. Dev. & Mean & Std. Dev. & \\
\hline \multicolumn{8}{|l|}{ Finger millet } \\
\hline Seeds (kg per acre) & 5.79 & 4.06 & 6.08 & 6.86 & 5.95 & 5.76 & \\
\hline Chemical fertilizer (kg per acre) & 22.96 & 34.13 & 27.55 & 37.86 & 25.47 & 36.23 & \\
\hline Labor (days per acre) & 129.94 & 82.76 & 132.40 & 89.47 & 131.31 & 86.35 & \\
\hline Yield (kg per acre) & 291.58 & 269.05 & 357.41 & 309.85 & 327.67 & 293.44 & $* *$ \\
\hline \multicolumn{8}{|l|}{ Maize } \\
\hline Seeds (kg per acre) & 7.70 & 3.98 & 7.12 & 3.97 & 7.38 & 4.00 & \\
\hline Chemical fertilizer (kg per acre) & 27.45 & 38.36 & 37.75 & 51.69 & 33.40 & 46.73 & $* *$ \\
\hline Labor (days per acre) & 95.14 & 66.59 & 77.79 & 55.76 & 85.52 & 61.31 & $* *$ \\
\hline Yield (kg per acre) & 513.00 & 382.34 & 676.77 & 636.45 & 603.84 & 543.52 & $* *$ \\
\hline
\end{tabular}

Looking at gender differences in the production of the two crops, we find that female farmers obtain lower yields per acre in both, finger millet and maize production. At the same time, female and male finger millet producers do not use significantly different quantities of inputs. In maize production, we find that female producers have a significantly lower fertilizer input, but a significantly higher labor input compared to male farmers. The fact that we do find significant differences in yields but not in input use between female and male finger millet producers could be an indication for lower average levels of technical efficiency among female finger millet producers. 


\subsection{Estimating technical efficiency}

\subsubsection{Econometric model}

Efficiency estimation using stochastic frontier models was first proposed by Aigner et al. (1977) and Meeusen and van den Broeck (1977) and has since then become a well established strand of literature in agricultural economics (Battese 1992). Stochastic frontier models are frequently applied to measure the technical efficiency of different production systems (Wollni \& Brümmer 2012; Gebregziabher et al. 2012; Jha \& Rhodes 1999; Grabowski \& Pasurka 1989). As opposed to OLS models that depict the average technology used by the farms, a production frontier reflects the technology of the best performing farms in the sample (Coelli 1995). We estimate the production frontier using a Cobb-Douglas functional form, which has been widely used in efficiency analyses (Battese 1992; Bravo-Ureta 1997). An alternative to the Cobb-Douglas functional form is the translog functional form. While translog functions are more flexible than Cobb-Douglas functions and do not assume constant elasticities of production and substitution, they often lead to problems of multicollinearity ${ }^{27}$. Previous authors have argued that the Cobb-Douglas functional form is adequate as long as the interest of the analysis lies in the efficiency estimation and not in the structure of the production technology (Taylor 1986; Binam et al. 2004). Our stochastic frontier model is specified as:

$$
\ln Y_{i}=\alpha_{0}+\sum_{j=1}^{j} \alpha_{j} \ln X_{j i}+\sum_{k=1}^{k} \alpha_{k} \ln D_{k i}+v_{i}-u_{i}
$$

where $Y_{i}$ represents the scalar output of farmer $i, X_{j i}$ is a vector of input quantities and cropping area, and $D_{k i}$ is a vector of dummy variables reflecting cropping practices and location specific dummies. Following Aigner et al. (1977) and Battese and Coelli (1995), the error term is defined as $\varepsilon_{i}=v_{i}-u_{i}$, where $v_{i}$ is a random error term and $u_{i}$ is a function of a set of independent variables influencing inefficiency. The distribution of $u_{i}$ is assumed to be a truncated non-negative

\footnotetext{
${ }^{27}$ This is the case in our study, where the translog functional form is subject to problems of multicollinearity when applied to our data.
} 
normal distribution that is independent of $v_{i}$ and with mean $\mu_{i}$. The impact of household specific independent variables on technical inefficiency is then modeled as:

$$
\mu_{i}=\sum_{l=1}^{l} \alpha_{l} Z_{l i}+e_{i}
$$

where $Z_{l i}$ is a vector of household specific variables influencing technical inefficiency, $\alpha_{l}$ is a vector of parameters to be estimated, and $e_{i}$ is a random error term. The production frontier and the inefficiency equation are estimated for both, finger millet and maize production.

The production frontier is defined as a function of input quantities and cropping practices. Input quantities include seeds (in kg), chemical fertilizer (in $\mathrm{kg}$ ), and labor days. To avoid biased estimates caused by a large number of zero values in the quantity of chemical fertilizer, we follow Battese (1997) and include a dummy variable that takes on the value one if a farmer did not use any chemical fertilizer. Concerning the cropping practices, we include dummy variables for early planting, the use of an ox plough or tractor plough, the use of a modern variety, and the use of organic fertilizer $^{28}$. All else constant, these cropping practices are expected to shift the production frontier upwards. To account for regional differences in agro-ecological conditions, we include altitude and a dummy variable for high soil fertility.

The inefficiency equation contains a range of variables reflecting the farmers' management skills and their access to productive resources. Since female farmers often face larger barriers to access productive resources (Croppenstedt et al. 2013; Kilic et al. 2013), we are particularly interested in the effect of gender on efficiency. A comprehensive literature review by Quisumbing (1996) did not find systematic differences in production efficiencies between female and male farmers. However, the study also revealed severe methodological shortcomings of many studies. A common weakness of microeconomic studies is the simplistic differentiation between female and male headed households, without taking into account who in the household is actually growing and marketing the

\footnotetext{
${ }^{28}$ The farmers in our survey had difficulties to exactly quantify the amount of organic fertilizer used. We therefore only include a dummy to control for the use of organic fertilizer.
} 
crop. A study by Saito et al. (1994) showed plot-level differences in productivity between women and men, but no significant household-level differences between male and female headed households. To capture gender differences more accurately, we therefore include a dummy that takes on the value one if the crop is grown and marketed by a female household member ${ }^{29}$. Previous research has shown that farmers who are linked to other farmers, markets, and agricultural service providers achieve higher levels of efficiency than less connected farmers (Binam et al. 2003; Backman et al. 2011; Rao et al. 2012; Wollni \& Brümmer 2012). To reflect the households' capability to connect with other farmers, markets, and agricultural service providers, we include group membership, ownership of a cell phone, and farm size as potential determinants of efficiency. Group membership is measured as the number of village groups a household participates in. Most village groups in our research area are multipurpose groups that are involved in agricultural as well as nonagricultural activities. Group membership can improve efficiency through the reduction of transaction costs and better access to extension services, information, markets, and productive resources (Binam et al. 2004; Wollni, Brümmer 2012). Similarly, the ownership of a cell phone is expected to increase a household's connectedness and thus the level of efficiency. Farm size is often used as a proxy for household wealth in rural settings of developing countries, where access to land resources is closely associated with access to collateral, credit markets and income (Eswaran \& Kotwal 1986). Since wealthier households are usually better connected and have better access to productive resources, we expect farm size to have a positive effect on efficiency (Carter \& Wiebe 1990).

Besides gender and connectedness, other farm- and household characteristics such as age, education, and labor endowment can potentially influence inefficiency and are included in our model. Based on results from previous studies, we expect younger and more educated farmers to

\footnotetext{
${ }^{29}$ That means the female household member makes production decisions and disposes of the crop after harvest. This distinction is important because if the woman only makes production decisions, but does not dispose of the crop after harvest, she might face a different incentive structure.
} 
achieve higher levels of efficiency (Phillips \& Marble 1986; Bravo-Ureta \& Pinheiro 1997; Wollni \& Brümmer 2012). The number of adults in a household reflects family labor availability, which can affect efficiency either way. On the one hand, family labor is not associated with the same incentive and coordination problems as hired labor and may therefore result in higher levels of efficiency (Eswaran \& Kotwal 1986). On the other hand, the existence of excess family labor can lead to a less efficient use of family labor in on-farm production activities (Wollni \& Brümmer 2012). Finally, location dummies are included to control for location specific differences in market access and infrastructure. A detailed description of all variables used in the production frontier and the inefficiency equation is provided in Table A.3 in the annex.

\subsubsection{Results}

The parameter estimates from the stochastic frontier models on maize and finger millet production are presented in Table 4.3. Results of the finger millet production function indicate that all variable inputs have a positive and significant influence on the quantity of finger millet produced. The partial production elasticities for seeds, fertilizer, labor, and cropping area are $0.299,0.136,0.255$, and 0.489 , respectively. The null hypothesis that the resulting scale elasticity of 1.178 does not significantly differ from one cannot be rejected at the $10 \%$ significance level, indicating constant returns to scale. In the case of maize, increases in the production area, the seed quantity and chemical fertilizer result in a significant increase of the quantity of maize produced, while an increase in labor does not have a significant influence. The partial production elasticities of 0.422 for seeds, 0.217 for fertilizer, 0.075 for labor, and 0.409 for cropping area sum up to a scale elasticity of 1.123. Again, the null hypothesis of constant returns to scale cannot be rejected. Among the technology shifters, the use of a modern variety increases output quantities for both crops. All other factors held constant, the use of a modern variety increases finger millet output by $29 \%$ and maize output by $21 \%$. We furthermore find that the use of an ox-plough or tractor for soil preparation and 
the use of organic fertilizer have a positive effect on finger millet quantity, but do not influence maize quantity. Ceteris paribus, finger millet production increases by $29 \%$ when an ox plough or a tractor plough is used and by $26 \%$ if organic fertilizer is applied.

Table 4.3: Efficiency model results

\begin{tabular}{|c|c|c|c|c|c|c|}
\hline & \multicolumn{3}{|c|}{ Model 1: Finger millet } & \multicolumn{3}{|c|}{ Model 2: Maize } \\
\hline & Coefficient & & Std. Err. & Coefficient & & Std. Err. \\
\hline \multicolumn{7}{|l|}{ Production frontier } \\
\hline Seeds (In) & .299 & $* * *$ & .083 & .422 & $* * *$ & .102 \\
\hline Fertilizer (In) & .136 & $*$ & .073 & .217 & $* * *$ & .045 \\
\hline Labor (In) & .255 & $* *$ & .114 & .075 & & .073 \\
\hline Cropping area (In) & .488 & $* * *$ & .099 & .409 & $* * *$ & .104 \\
\hline Zero fertilizer & .086 & & .247 & .192 & & .184 \\
\hline Ox plough / tractor & .286 & $* *$ & .120 & .115 & & .093 \\
\hline Early sowing & .150 & & .116 & .089 & & .086 \\
\hline Modern variety & .293 & $*$ & .171 & .213 & $* *$ & .102 \\
\hline Organic fertilizer & .258 & $* *$ & .123 & .082 & & .074 \\
\hline Altitude & .000 & & .000 & .000 & & .000 \\
\hline Soil fertility & -.079 & & .113 & .129 & & .104 \\
\hline Constant & 3.334 & $* * *$ & .994 & 3.656 & $* * *$ & .885 \\
\hline \multicolumn{7}{|l|}{ Inefficiency equation } \\
\hline Female crop & .565 & $* *$ & .246 & -.202 & & .404 \\
\hline Group membership & -.362 & $* *$ & .150 & -.197 & & .154 \\
\hline Cell phone & .439 & & .401 & -.070 & & .459 \\
\hline Head age & .006 & & .010 & .024 & & .016 \\
\hline Secondary education & .167 & & .281 & -.477 & & .397 \\
\hline Adults & -.031 & & .078 & -.020 & & .134 \\
\hline Farm size & -.023 & & .048 & -.027 & & .074 \\
\hline Constant & .349 & & .896 & -2.957 & & 2.947 \\
\hline $\mathrm{N}$ & & & 265 & & & 253 \\
\hline Wald chi ${ }^{2}(11)$ & & & 208.460 & & & 342.610 \\
\hline Log pseudolikelihood & & & -1128.095 & & & -731.193 \\
\hline Prob > chi ${ }^{2}$ & & & .000 & & & .000 \\
\hline
\end{tabular}

The results of the inefficiency effects models are also presented in Table 4.3. We use a likelihood ratio test to test whether the potential inefficiency determinants are jointly significant. The null hypothesis that all variables are insignificant is rejected with an error probability of $1 \%$ for both models. For the interpretation of the inefficiency effects, it is important to note that a negative (positive) sign on a coefficient implies a positive (negative) effect on efficiency.

In the case of finger millet, we find that female producers are on average less efficient than male producers. This finding contradicts the results from previous studies that female farmers produce as 
efficiently as male farmers within their given resource constraints (Quisumbing 1996; Alene et al. 2008). Furthermore, the number of village groups a household participates in has a significant influence on technical efficiency in finger millet production. This finding is in line with the results of previous studies emphasizing the importance of farmer networks to achieve efficiency (Binam et al. 2004; Wollni \& Brümmer 2012). The significant effect of group membership has to be interpreted against the background that a large number of the village groups in our research area have received extension from KARI. The positive influence of group membership on technical efficiency can therefore not necessarily be interpreted as a farmer-to-farmer learning effect, but rather as the effect of improved access to extension services and other formal sources of information among group members. In the case of maize, none of the included variables has a significant influence on efficiency.

Table 4.4 reports average technical efficiency estimates in finger millet and maize production for the whole sample and by gender. In the case of maize production average technical efficiency is estimated at $72 \%$. This represents a relative measure of efficiency compared to the most efficient maize farmers in the sample. Still, compared to other efficiency studies conducted in the context of developing countries (Kaliba 2004; Tchakounte et al. 2012), this represents a relatively high average level of technical efficiency. In finger millet production, average technical efficiency is estimated at $54 \%$, indicating that farmers produce substantially further away from the best practice production frontier. While female and male farmers obtain the same average level of efficiency in maize production, female farmers obtain substantially lower average levels of technical efficiency than male farmers in finger millet production.

Table 4.4: Technical efficiency estimates

\begin{tabular}{lrrrrrr} 
& \multicolumn{2}{c}{ Female producers } & \multicolumn{2}{c}{ Male producers } & \multicolumn{2}{c}{ All producers } \\
\cline { 2 - 7 } & Mean & Std. Dev. & Mean & Std. Dev. & Mean & Std. Dev. \\
\hline Model 1: Finger millet & .51 & .21 & .57 & .19 & .54 & .20 \\
Model 2: Maize & .72 & .17 & .72 & .17 & .72 & .17 \\
\hline
\end{tabular}


These findings are also confirmed when looking at the distribution of technical efficiency estimates. Figures 4.1 and 4.2 illustrate the high level of average technical efficiency in maize production and the much larger variability of efficiency estimates in finger millet production. Furthermore, Figures 4.3 to 4.6 illustrate that the high variability of technical efficiency in finger millet production can mainly be attributed to the high share of female farmers with low efficiency estimates. At the same time, the distribution of efficiency estimates in maize production does not vary substantially between female and male producers.

Considering the finding that village group membership increases technical efficiency in finger millet production but not in maize production, the different distributions of technical efficiency estimates indicate a different availability of extension services and information for the two crops. Since maize extension services and information on maize production are widely available throughout the country, achieving a high level of technical efficiency is not exclusive to a certain group of farmers in the case of maize. In the case of finger millet, information and extension are scarce and only accessible for farmers who are well connected. Especially female farmers seem to be negatively affected by the sparse availability of information on finger millet production. Besides a particularly poor access to information among female farmers, the prioritization of male plots is another possible reason for the low levels of efficiency among female farmers (Udry 1996). Anecdotal evidence suggests that female farmers often have to help on their husbands plots before turning to their own plots. In some cases, this might lead to delayed weeding or harvesting and thus to a less efficient use of labor and other inputs. 
Figure 4.1: Finger millet production

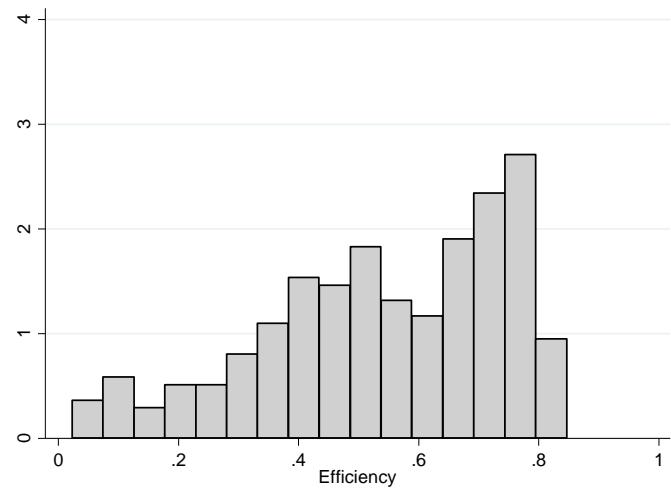

Figure 4.2: Female finger millet producers

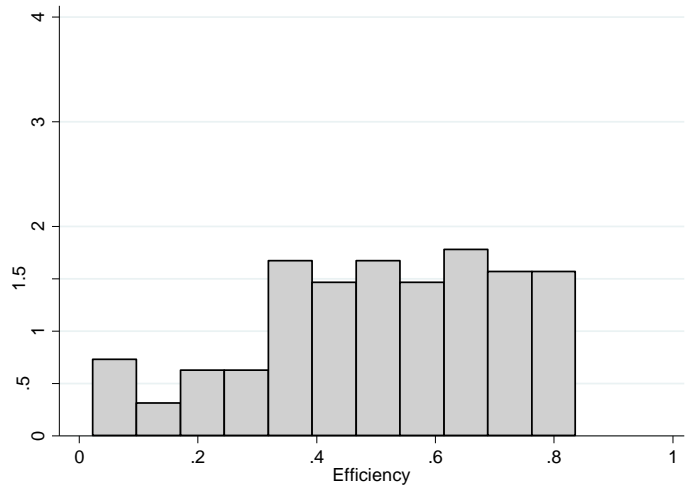

Figure 4.3: Male finger millet producers

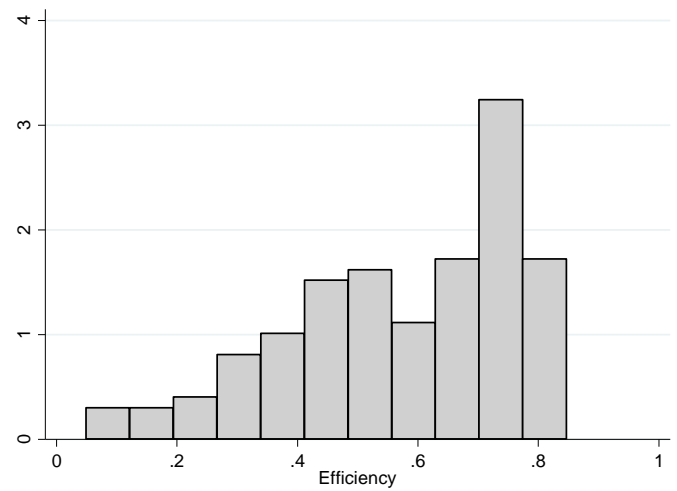

Figure 4.4: Maize production

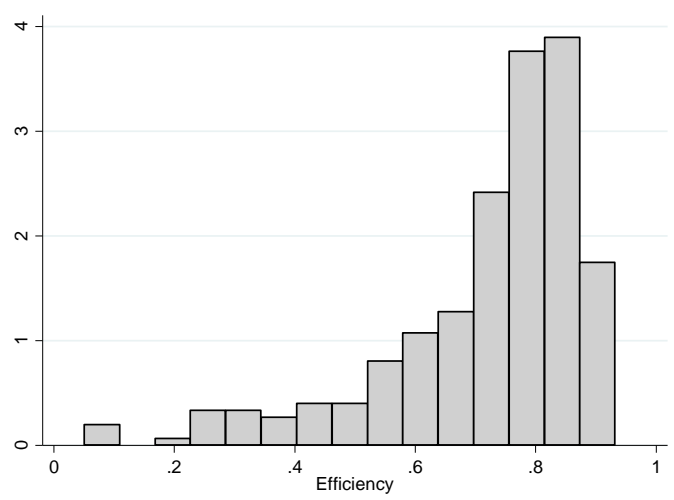

Figure 4.5: Female maize producers

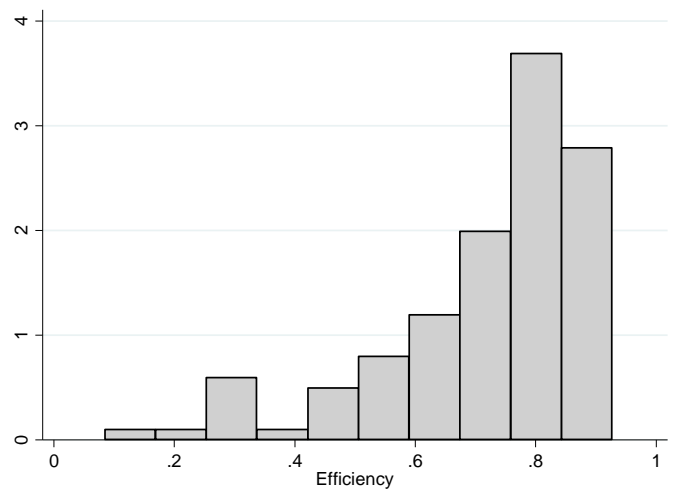

Figure 4.6: Male maize producers

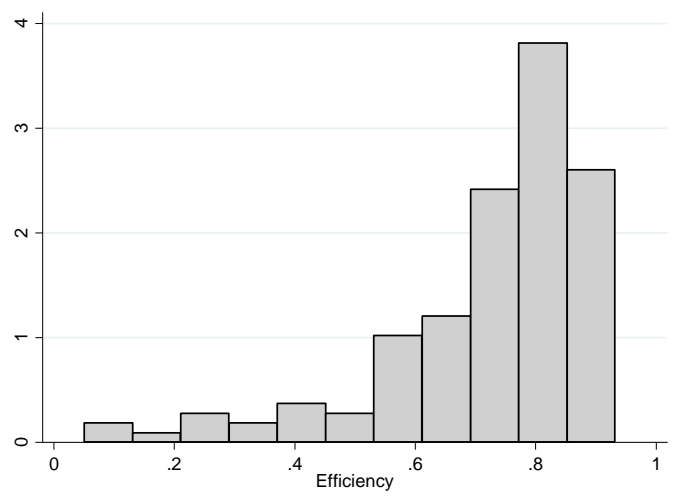




\subsection{Profitability analysis}

To assess the profits derived from finger millet and maize production and gender differences in the profitability of the two crops, we calculate the costs, revenues, and profits per acre. The production costs are depicted in Table 4.5. In the case of seeds, many farmers use their own seeds instead of buying seeds. For those farmers, the average finger millet price at the village level is calculated as the opportunity costs of not selling the seeds on the local market. In addition to wage labor expenditures, labor opportunity costs for the exchange labor and family labor have to be taken into account. The average daily wage for a farm worker in our sample is 143 KES per day, with 100 KES per day being the most common wage, which was paid in $42 \%$ of the cases. We used the most common wage of 100 KES per day to calculate labor opportunity costs. The total production costs per acre are first calculated without taking labor opportunity costs into account and then with taking labor opportunity costs into account. In a few households of our sample, finger millet or maize is produced by a female household member but sold by a male household member. Those households are excluded from the remainder of our analysis.

In finger millet production, female and male producers spend roughly the same amount of money for seeds and fertilizer, but male farmers spend significantly more money on wage labor. If labor opportunity costs are not taken into account, male farmers also have higher total expenditures than female farmers. In the case of maize, male farmers spend on average more money on chemical fertilizer, but have lower labor opportunity costs than female farmers. Total expenditures do not differ significantly between male and female farmers in maize production. When only calculating with the production costs for seeds, fertilizer, and wage labor, average expenditures per acre of finger millet are only slightly higher than average expenditures per acre of maize $\left(7129 \mathrm{KES}^{30}\right.$ per acre in finger millet production as compared to 6430 KES per acre in maize production). However, the difference in production costs increases when labor opportunity costs are taken into account

\footnotetext{
${ }^{30}$ KES = Kenyan Shilling
} 
$(16,677$ KES per acre in finger millet production as compared to 12,851 KES per acre in maize production).

Table 4.5: Input costs per acre

\begin{tabular}{|c|c|c|c|c|c|c|c|}
\hline & \multicolumn{2}{|c|}{ Female producers } & \multicolumn{2}{|c|}{ Male producers } & \multicolumn{2}{|c|}{ All producers } & \\
\hline & Mean & Std. Dev. & Mean & Std. Dev. & Mean & Std. Dev. & \\
\hline \multicolumn{8}{|l|}{ Finger millet } \\
\hline Chemical fertilizer (KES) & 1678.60 & 2783.83 & 1747.06 & 2418.27 & 1714.81 & 2591.99 & \\
\hline Seeds (KES) & 631.68 & 950.17 & 551.45 & 701.87 & 589.24 & 827.46 & \\
\hline Wage labor (KES) & 4125.73 & 5690.05 & 5448.33 & 8019.60 & 4825.33 & 7037.32 & $*$ \\
\hline Labor opportunity costs (KES) & 9895.83 & 9138.89 & 9237.67 & 8725.84 & 9547.69 & 8911.47 & \\
\hline $\begin{array}{l}\text { Total costs per acre (KES, excl. } \\
\text { labor opportunity costs) }\end{array}$ & 6436.00 & 6895.18 & 7746.84 & 8901.79 & 7129.38 & 8031.08 & * \\
\hline $\begin{array}{l}\text { Total costs per acre (KES, incl. } \\
\text { labor opportunity costs) }\end{array}$ & 16331.82 & 9482.99 & 16984.51 & 10404.36 & 16677.07 & 9967.15 & \\
\hline \multicolumn{8}{|l|}{ Maize } \\
\hline Chemical fertilizer (KES) & 1885.24 & 2860.28 & 2458.49 & 3593.29 & 2210.95 & 3303.19 & * \\
\hline Seeds (KES) & 1040.97 & 1347.22 & 891.35 & 772.30 & 959.58 & 1073.60 & \\
\hline Wage labor (KES) & 3094.18 & 8913.01 & 3171.09 & 4455.05 & 3136.02 & 6842.08 & \\
\hline Labor opportunity costs (KES) & 7370.45 & 6838.49 & 5624.22 & 6263.27 & 6420.50 & 6576.52 & $* *$ \\
\hline $\begin{array}{l}\text { Total costs per acre (KES, excl. } \\
\text { labor opportunity costs) }\end{array}$ & 6020.39 & 10801.36 & 6774.01 & 6542.17 & 6430.36 & 8734.56 & \\
\hline $\begin{array}{l}\text { Total costs per acre (KES, incl. } \\
\text { labor opportunity costs) }\end{array}$ & 13390.84 & 11438.03 & 12398.24 & 8005.40 & 12850.86 & 9714.06 & \\
\hline
\end{tabular}

We calculate gross revenues per acre by multiplying yields and selling prices. Finger millet was marketed by $64 \%$ and maize by $49 \%$ of the interviewed farmers in 2011 . Among those farmers who marketed finger millet or maize, the average selling price was 55 KES per kg of finger millet and 31 KES per kg of maize. For those farmers who did not sell any finger millet or maize, we used the average selling price at the village level to calculate gross revenue. Table 4.6 shows that the average selling prices obtained by women do not vary significantly from the average selling prices obtained by men. However, the higher yields obtained by men result in significantly higher revenues and profits in both, finger millet and maize production.

The average gross revenue in finger millet production is 19,309 KES per acre, which is slightly higher than the average gross revenue of 18,953 KES per acre that is obtained in maize production. 
Subtracting production costs for seeds, fertilizer and wages from the grow revenue; the average profit obtained from maize production (12,428 KES per acre) is slightly higher than the average profit obtained from finger millet production (12,133 KES per acre). The difference between profits obtained from finger millet and maize production becomes more pronounced when labor opportunity costs are taken into account. The remaining average profit of 6103 KES per acre of maize production is more than twice as large as the remaining average profit of 2598 KES per acre of finger millet production.

Table 4.6: Yields and profits

\begin{tabular}{|c|c|c|c|c|c|c|c|}
\hline & \multicolumn{2}{|c|}{ Female producers } & \multicolumn{2}{|c|}{ Male producers } & \multicolumn{3}{|c|}{ All producers } \\
\hline & Mean & Std. Dev. & Mean & Std. Dev. & Mean & Std. Dev. & \\
\hline \multicolumn{8}{|l|}{ Finger millet } \\
\hline Selling price (KES) & 55.56 & 20.76 & 54.83 & 14.26 & 55.19 & 17.7332 & \\
\hline Gross revenue per acre & 16890.14 & 17993.91 & 21461.57 & 21129.34 & 19309.26 & 19809.88 & $* *$ \\
\hline $\begin{array}{l}\text { Profit1 per acre (excl. labor } \\
\text { opportunity costs) }\end{array}$ & 10416.82 & 17237.82 & 13659.24 & 19718.77 & 12132.65 & 18626.92 & $*$ \\
\hline $\begin{array}{l}\text { Profit2 per acre (incl. labor } \\
\text { opportunity costs) }\end{array}$ & 571.44 & 18300.62 & 4401.44 & 20488.41 & 2598.21 & 19545.46 & $*$ \\
\hline \multicolumn{8}{|l|}{ Maize } \\
\hline Selling price (KES) & 31.15 & 8.33 & 31.33 & 8.79 & 31.25 & 8.56 & \\
\hline Gross revenue per acre & 16014.49 & 1143.76 & 21417.06 & 21217.05 & 18953.49 & 17860.93 & $* * *$ \\
\hline $\begin{array}{l}\text { Profit } 1 \text { per acre (excl. labor } \\
\text { opportunity costs) }\end{array}$ & 9738.54 & 12846.49 & 14682.59 & 18566.96 & 12428.11 & 16367.19 & $* * *$ \\
\hline $\begin{array}{l}\text { Profit } 2 \text { per acre (incl. labor } \\
\text { opportunity costs) }\end{array}$ & 2623.65 & 14522.61 & 9018.83 & 18971.11 & 6102.63 & 17350.12 & $* * *$ \\
\hline
\end{tabular}

Altogether, the profitability analysis shows that women obtain significantly lower profits from the production of the two crops than men, a finding that can mainly be attributed to the lower yields obtained by women. In the case of finger millet, the low technical efficiency obtained by women is one reason for the lower yields. The profitability analysis furthermore shows that the high labor requirements of finger millet production make finger millet a substantially less profitable crop than maize. This finding is also reflected in the farmers' own perception concerning the advantages and disadvantages of finger millet in comparison to maize. When asking farmers about the main 
disadvantages of finger millet, the high labor requirements in finger millet production are seen as the most important disadvantage by $46 \%$ of the farmers (see Table 4.7 ). Other farmers mentioned the taste $(27 \%)$ and the seed availability $(21 \%)$ as the main disadvantages of finger millet. In terms of advantages, the nutritional value of finger millet is pointed out as the main advantage by $48 \%$ of the farmers, followed by better marketing opportunities (32\%) and more suitable agronomic properties such as resistance to pests and droughts (12\%).

Table 4.7: Advantages and disadvantages of finger millet in comparison to maize

\begin{tabular}{llll} 
Main advantages & \multicolumn{3}{c}{ Main disadvantages } \\
\hline Nutritional value & $(48 \%)$ & Labor requirements & $(46 \%)$ \\
Marketing/prices & $(32 \%)$ & Taste & $(27 \%)$ \\
Agronomic properties & $(12 \%)$ & Seed availability & $(21 \%)$ \\
\hline
\end{tabular}

\subsection{Conclusions}

While many farmers in developing countries have shifted from the production of traditional food crops to the production of main staple crops such as maize, traditional food crops have an important potential to improve micronutrient supply and the resilience of agricultural systems in many regions of the developing world. For this potential to be used, traditional food crops need to be an attractive cropping option for small-scale farmers, who need to derive food and income from their constrained production possibilities. The present paper seeks to assess the economic attractiveness and the technical efficiency of the traditional food crop finger millet in comparison to the main staple crop maize in western Kenya.

Using stochastic frontier models, we show that technical efficiency estimates are $54 \%$ in finger millet production and $72 \%$ in maize production. We find that participation in village groups increases technical efficiency in finger millet production but not in maize production. A possible reason for this finding is the poor access to extension services and other forms of information in the case of finger millet, which requires farmers to be well connected in order to get information on finger millet production. We furthermore find that female farmers produce significantly less efficiency than their 
male counterparts in the case of finger millet, while female and male farmers obtain similar levels of efficiency in maize production. Besides a lack of access to information among female finger millet processors, a prioritization of male plots is a possible explanation for this finding.

In terms of profitability, we find that finger millet production is less profitable than maize production and that women obtain significantly lower profits than men in the production of both crops. The low profitability of finger millet production can on the one side be attributed to the lower yield potential and the higher labor requirements in finger millet production. On the other side, the low level of technical efficiency is an additional reason for the low profits in finger millet production. There is a range of possible reasons for the low yields and the subsequent low profits obtained by women. In the case of finger millet, an inefficient use of inputs by women is one of the reasons.

Altogether, the results show that finger millet production is currently not an economically viable alternative to maize production. The large gap between the average efficiency and the efficiency of the best performing farms indicates that efficiency gains in finger millet production are one important factor to improve the competitiveness of the crop. Besides the development and dissemination of improved technologies such as improved seeds and labor reducing production techniques, enabling farmers to use their available inputs and technologies more efficiently is therefore an important policy objective. A better provision of finger millet extension and other forms of information concerning finger millet production is one way to achieve this objective. Against the background that women depend to a much larger extend on the income derived from finger millet production than men, the low levels of technical efficiency among female finger millet producers is a worrying finding. Service providers such as extension agencies therefore have to make sure that women are not disadvantaged in the access to their services. 
Technical efficiency and profitability of traditional food crop production 
Part five

5 Conclusions 


\subsection{Findings}

Traditional food crops play an important role in improving food security and alleviate poverty in rural areas of developing countries. Their agronomic properties such as drought and heat resistance have the potential to make agricultural systems more resilient. At the same time, many traditional food crops are rich in essential micronutrients and represent an important income opportunity for smallscale farmers. Yet, traditional food crops have been widely neglected by researchers and policy makers in the past century. Subsequently, there have been little genetic improvements, value chains remain poorly developed, and most farmers have switched from traditional food crop production to the production of main staple crops such as maize, rice, and wheat. The case of finger millet in western Kenya is one example for a traditional food crop that has been widely neglected and replaced by a main staple crop - in this case maize. Finger millet is nowadays a marginalized crop in western Kenya and its potential in terms of micronutrient supply, poverty alleviation, and a higher resilience of agricultural production systems is largely untapped. Based on household survey data, the present dissertation assesses the potential and constraints of finger millet production and marketing in comparison to maize. Specifically, the adoption of improved cropping practices, the technical efficiency, the marketing opportunities, and the profitability in finger millet production are assessed. While many studies have focused on these issues in the past, empirical evidence on traditional food crop production and marketing remains scarce.

An adoption of improved agricultural practices is a major precondition to achieve competitive yields. Altogether, adoption rates for improved varieties and chemical fertilizer are lower in finger millet than in maize production. A multivariate probit analysis reveals that variables related to social networks have a significant and positive influence on the adoption of improved finger millet practices, while the same variables only have a marginal influence on the adoption of improved maize practices. Likewise, extension services related to finger millet increase the adoption of improved practices, while extension services related to maize do not have a significant influence on 


\section{Conclusions}

cropping practices. A likely reason for this finding is the sparse availability of information and improved seeds in the case of finger millet, which makes them only accessible for well-connected farmers. Results from a Cobb-Douglas production function indicate that the use of modern varieties and chemical fertilizer have a strong positive effect on finger millet yields.

Besides the adoption of improved practices, a technically efficient use of the available inputs is necessary to obtain competitive yields. Two stochastic frontier models are specified to estimate the technical efficiency in finger millet and maize production, respectively. The average level of technical efficiency is found to be substantially lower in finger millet than in maize production. Among the variables that have a potential influence on technical efficiency, group membership is found to increase technical efficiency in finger millet but not in maize production. As in the case of technology adoption, the low level of information availability is a likely reason for the importance of social networks in finger millet production. Women are found to produce less efficiently than men in the case of finger millet, but not in the case of maize.

Most farmers do not only cultivate food crops to satisfy the subsistence needs of their families, but also to generate income from their production. Market access and marketing opportunities are therefore important factors for the attractiveness of a certain food crop to the farmers. The income derived from food crops plays a particularly important role for the smallest and least endowed farmers who do not access high-value agricultural markets. A probit model on the decision to market finger millet reveals that marketing barriers are low. Variables related to market access such as market distance and the ownership of a cell phone are not significant in the analysis. Poorer farmers do not face particular marketing barriers and are on the contrary even more likely to sell finger millet than wealthier farmers. Likewise, female farmers are more likely to market finger millet than male farmers. Different model specifications show that group membership significantly increases the probability of market participation. In terms of selling prices, results from a linear regression show that female sellers are disadvantaged unless they are organized in a finger millet group. Altogether, 


\section{Conclusions}

a weak coordination along the finger millet value chain can be observed. While processors complain about a lack in supply, farmers lack in good marketing opportunities and middlemen earn high margins from trading finger millet.

Despite the high finger millet market prices, the profitability of finger millet production is substantially lower than the profitability of maize production. This finding can mainly be attributed to the low yields and high labor requirements in finger millet production. Besides the lower genetic yield potential of finger millet, lower adoption rates of improved technologies and lower levels of technical efficiency are underlying reasons for the low profitability of finger millet production. Women obtain significantly lower yields in the production of both crops and therefore make less profit than their male counterparts.

\subsection{Policy implications}

Three main findings can be derived from the present dissertation. First, social networks such as farmer groups play a particularly important role in the production of traditional food crops, since information and modern inputs are not widely available. Second, women face bigger challenges in generating high yields and profits from traditional food crop production than men, which makes social networks even more important for female farmers. Third, a traditional food crop like finger millet is currently not an economically viable production choice for small-scale farmers if compared to maize. These findings have implications for the design of policy interventions in the field of food crop production and marketing.

The finding that finger millet is not an economically viable cropping option in comparison to maize leaves policy makers with two choices: Either abandoning finger millet from their agendas, or undertake measures that improve the competitiveness of finger millet in the region. Abandoning the crop would however lead to a loss of the crop's potential and a loss of genetic diversity in the farming systems of the region. 


\section{Conclusions}

On the production side, finger millet yields are found to be substantially lower than maize yields. The econometric analyzes of the present dissertation show that the low finger millet yields can not only be attributed to a low yield potential of the crop, but are also the result of low adoption rates of improved technologies and low levels of technical efficiency. Besides the development of new technologies, a better dissemination of existing technologies and achieving more efficient production systems are therefore important policy objectives. Extension programs that are specifically targeting traditional food crops are found to have a significant effect on the adoption of improved practices. Village groups enable farmers to access information and inputs. The provision of targeted extension services as well as strengthening farmer networks are two essential policy measures in order to reach these objectives. Although gender does not have a significant effect on the adoption of improved cropping practices, female farmers produce significantly less efficiently than their male counterparts. Policy makers should therefore specifically target women in their interventions.

In terms of marketing, no substantial barriers are found for the sale of finger millet. However, market coordination is weak, middlemen obtain high trading margins, and selling prices vary greatly. In addition, female farmers obtain significantly lower selling prices than their male counterparts unless they are organized in groups. In order to improve market coordination, policy measure to link farmers better to large traders and processors are needed. Although services for that purpose are already available in the country, they are not widely used. Promoting and improving those services can be a way of achieving more market coordination. Furthermore, already existing price information services have to become better known and more available to small-scale farmers. Last but not least, women have to be strengthened in the marketing process, e.g. through a strengthening of female group marketing efforts. 


\subsection{Limitations}

The research results presented in this dissertation are subject to various limitations. Two major limitations can be identified. First and foremost, a small and cross-sectional sample is used for the econometric analyses, which potentially leads to endogeneity and selection biases in the model estimations. Second, a range of important research questions could not be addressed with the available data.

We try to avoid endogenous variables in the regression analyses and employ statistical methods to control for potential endogeneity. For example, we employ a treatment effects model in the yield analysis to control for endogeneity in the adoption of modern varieties. On the other hand, we cannot control for endogeneity for all inputs, input quantities, or technologies used. In our marketing analysis, we estimate a Heckman sample selection model to control for potential selection bias. We furthermore employ an instrumental variable approach to control for potential endogeneity of group membership in the market participation and the selling price model. Again, we cannot control for endogeneity for all independent variables in our model. While we are confident that the independent variables used in the efficiency analysis are exogenous, we do not control for endogeneity in the production frontier models. An appropriate way of avoiding endogeneity problems would be to build up a panel data set which can control for fixed effects in the analysis.

Important research questions that could not be addressed in the present dissertation include for example the impact of finger millet production on household food security. We know that finger millet contains a range of micronutrients that many people in the region lack. However, we do not know if households that cultivate finger millet have a higher intake of these micronutrients. Households that do not cultivate finger millet might buy finger millet on the local market or derive their micronutrient supply from other crops. To assess this research question, a sample that includes both finger millet producers as well as non-finger millet producers is necessary. Furthermore, 


\section{Conclusions}

biometric data or very detailed data on household food consumption and the micronutrient contents of different foods would be needed for such an analysis. 


\section{Publication Bibliography}

Abdoulaye, T.; Sanders, J. H. (2006): New technologies, marketing strategies and public policy for traditional food crops: Millet in Niger. In Agricultural Systems 90 (1), pp. 272-292.

Abler, D. G.; Sukhatme, V. A. (2006): The "efficient but poor" hypothesis. In Applied Economic Perspectives and Policy 28 (3), pp. 338-343.

Ackello-Ogutu, C.; Echessah, P. (1997): Unrecorded cross-border trade between Kenya and Uganda: Implications for Food Security. In SD Publication Series, Office of Sustainable Development, Bureau for Africa. Technical Paper No. 59.

Aigner, D.; Lovell, C. A. L.; Schmidt, P. (1977): Formulation and estimation of stochastic frontier production function models. In Journal of econometrics 6 (1), pp. 21-37.

Alene, A. D.; Manyong, V. M.; Omanya, G. O.; Mignouna, H. D.; Bokanga, M.; Odhiambo, G. D. (2008): Economic efficiency and supply response of women as farm managers: Comparative evidence from western Kenya. In World Development 36 (7), pp. 1247-1260.

Ayliffe, M.; Singh, R.; Lagudah, E. (2008): Durable resistance to wheat stem rust needed. In Genome studies and Molecular Genetics, 11 (2), pp. 187-192.

Backman, S.; Zahidul Islam, K. M.; Sumelius, J. (2011): Determinants of Technical Efficiency of Rice Farms in North-Central and North-Western Regions in Bangladesh. In Journal of Developing Areas 45 (1), pp. 73-94.

Barham, J.; Chitemi, C. (2009): Collective Action Initiatives to Improve Marketing Performance. Lessons from Farmer Groups in Tanzania. In Food Policy 34 (1), pp. 53-59.

Barrett, C. B. (2008): Smallholder Market Participation. Concepts and Evidence from Eastern and Southern Africa. In Food Policy 33 (4), pp. 299-317.

Battese, G. E. (1992): Frontier production functions and technical efficiency: a survey of empirical applications in agricultural economics. In Agricultural Economics 7 (3), pp. 185-208.

Battese, G. E. (1997): A note on the estimation of Cobb-Douglas production functions when some explanatory variables have zero values. In Journal of Agricultural Economics 48 (1-3), pp. 250-252.

Battese, G. E.; Coelli, T.J. (1995): A model for technical inefficiency effects in a stochastic frontier production function for panel data. In Empirical economics 20 (2), pp. 325-332.

Baum, C. F., Schaffer, M. E.; Stillman, S. (2007). Enhanced routines for instrumental variables/generalized method of moments estimation and testing. In The Stata Journal 7 (4), pp. 465-506.

Bellemare, M. F.; Barrett, C. B. (2006): An ordered Tobit model of market participation. Evidence from Kenya and Ethiopia. In American Journal of Agricultural Economics 88 (2), pp. 324-337.

Bernard, T.; Taffesse, A. S.; Gabre-Madhin, E. (2008): Impact of Cooperatives on Smallholders' Commercialization Behavior: Evidence from Ethiopia. In Agricultural Economics 39 (2), pp. 147-161.

Besley, T.; Case, A. (1993): Modeling technology adoption in developing countries. In The American Economic Review 83 (2), pp. 396-402.

Binam, J. N.; Sylla, K.; Diarra, I.; Nyambi, G. (2003): Factors Affecting Technical Efficiency among Coffee Farmers in Côte d'Ivoire: Evidence from the Centre West Region. In African Development Review 15 (1), pp. 66-76. 
Binam, J.N.; Tonyè, J.; Wandji, N.; Nyambi, G.; Akoa, M. (2004): Factors affecting the technical efficiency among smallholder farmers in the slash and burn agriculture zone of Cameroon. In Food Policy 29 (5), pp. 531-545.

Boateng, M.; Ratchford, C. Brice; Blase, M. (1987): Profitability analysis of a farming system in Africa. In Agricultural Systems 24 (2), pp. 81-93.

Boughton, D.; Reardon, T. (1997): Will promotion of coarse grain processing turn the tide for traditional cereals in the Sahel? Recent empirical evidence from Mali. In Food Policy 22 (4), pp. 307-316.

Bravo-Ureta, B.E.; Pinheiro, A.E. (1997): Technical, economic, and allocative efficiency in peasant farming: evidence from the Dominican Republic. In The Developing Economies 35 (1), pp. 4867.

Byerlee, D.; Eicher, C. K. (1997): Africa's emerging maize revolution. London, UK: Lynne Rienner Publishers.

Cameron, A. C. \& Trivedi, P. K. (2009). Microeconometrics using Stata. College Station, USA: Stata Press.

Carter, M. R.; Wiebe, K. D. (1990): Access to capital and its impact on agrarian structure and productivity in Kenya. In American Journal of Agricultural Economics 72 (5), pp. 1146-1150.

Cavatassi, R.; Lipper, L.; Narloch., U. (2011): Modern variety adoption and risk management in drought prone areas: insights from the sorghum farmers of eastern Ethiopia. In Agricultural Economics 42 (3), pp. 279-292.

Christiaensen, L.; Demery, L. (2007): Down to earth: Agriculture and poverty reduction in Africa. Washington D. C., USA: The World Bank.

CIMMYT (2013): Curbing maize postharvest losses key to attaining food security in Kenya. Available online at http://blog.cimmyt.org/?p=10681, checked on 11/6/2013.

Coelli, T. J. (1995): Recent developments in frontier modelling and efficiency measurement. In Australian Journal of Agricultural and Resource Economics 39 (3), pp. 219-245.

Conelly, W. T.; Chaiken, M. S. (2000): Intensive farming, agro-diversity, and food security under conditions of extreme population pressure in western Kenya. In Human Ecology 28 (1), pp. 19-51.

Conley, T. G.; Udry, C. R. (2010): Learning about a new technology: Pineapple in Ghana. In The American Economic Review, pp. 35-69.

Croppenstedt, A.; Demeke, M.; Meschi, M. M. (2003): Technology adoption in the presence of constraints: The case of fertilizer demand in Ethiopia. In Review of Development Economics 7 (1), pp. 58-70.

Croppenstedt, A.; Goldstein, M.; Rosas, N. (2013): Gender and Agriculture: Inefficiencies, Segregation, and Low Productivity Traps. In World Bank Research Observer 28 (1), pp. 79109.

Crowley, E.; Carter, S. (2000): Agrarian Change and the Changing Relationships Between Toil and Soil in Maragoli, western Kenya (1900-1994). In Human Ecology 28 (3), pp. 383-414.

de Janvry, A.; Fafchamps, M.; Sadoulet, E. (1991): Peasant household behaviour with missing markets. some paradoxes explained. In The Economic Journal 101 (409), pp. 1400-1417.

Deaton, A. (1997). The Analysis of Household Surveys - A Microeconometric Approach to Development Policy. Baltimore, USA: The John Hopkins University Press. 
Dercon, S. (2009): Rural poverty: Old challenges in new contexts. In The World Bank Research Observer 24 (1), pp. 1-28.

Dolan, C. (2001): The 'Good Wife'. Struggles over Resources in the Kenyan Horticultural Sector. In The Journal of Development Studies 37 (3), pp. 39-70.

Doss, C. R. (2002): Men's Crops? Women's Crops? The Gender Patterns of Cropping in Ghana. In World Development 30 (11), pp. 1987-2000.

Doss, C. R.; Morris, M. L. (2000): How does gender affect the adoption of agricultural innovations? In Agricultural Economics 25 (1), pp. 27-39.

Eswaran, M.; Kotwal, A. (1986): Access to capital and agrarian production organisation. In The Economic Journal 96 (382), pp. 482-498.

Fafchamps, M. (1992): Cash Crop Production, Food Price Volatility, and Rural Market Integration in the Third World. In American Journal of Agricultural Economics 74 (1), pp. 90-99.

FAO (2012): CountrySTAT Kenya - Indicators. Available online at http://countrystat.org/ken/cont/pages/page/indicators/en, checked on 11/30/2012.

FAO (2013): FAOSTAT. Available online at http://faostat.fao.org/site/291/default.aspx, checked on $11 / 5 / 2013$.

Feder, G.; Just, R. E.; Zilberman, D. (1985): Adoption of agricultural innovations in developing countries: A survey. In Economic development and cultural change 33 (2), pp. 255-298.

Feder, G.; Umali, D. L. (1993): The adoption of agricultural innovations: a review. In Technological forecasting and social change 43 (3), pp. 215-239.

Feleke, S.; Zegeye, T. (2006): Adoption of improved maize varieties in Southern Ethiopia: Factors and strategy options. In Food Policy 31 (5), pp. 442-457.

Fischer, E.; Qaim, M. (2012a): Gender, agricultural commercialization, and collective action in Kenya. In Food Security 4 (3), pp. 441-453.

Fischer, E.; Qaim, M. (2012b): Linking Smallholders to Markets. Determinants and Impacts of Farmer Collective Action in Kenya. In World Development 40 (6), pp. 1255-1268.

Foster, A. D.; Rosenzweig, M. R. (1995): Learning by doing and learning from others: Human capital and technical change in agriculture. In Journal of political Economy, pp. 1176-1209.

Frison, E. A.; Cherfas, J.; Hodgkin, T. (2011): Agricultural biodiversity is essential for a sustainable improvement in food and nutrition security. In Sustainability 3 (1), pp. 238-253.

Frison, E. A.; Smith, I. F.; Johns, T.; Cherfas, J.; Eyzaguirre, P. B. (2006): Agricultural biodiversity, nutrition, and health: making a difference to hunger and nutrition in the developing world. In Food \& Nutrition Bulletin 27 (2), pp. 167-179.

Gebregziabher, G.; Namara, R. E.; Holden, S. (2012): Technical Efficiency of Irrigated and Rain-Fed Smallholder Agriculture in Tigray, Ethiopia: A Comparative Stochastic Frontier Production Function Analysis. In Quarterly Journal of International Agriculture 51 (3), pp. 203-226.

Gemech, F.; Struthers, J. (2007): Coffee price volatility in Ethiopia. Effects of market reform programmes. In Journal of International Development 19 (8), pp. 1131-1142.

Gill, G. J.; Turton, C. (2001): Pearl millet in developing countries. In International Sorghum and Millets Newsletter 2005 (42), pp. 1-8

Godfray, C.; Beddington, J.; Crute, I.; Haddad, L.; Lawrence, D.; Muir, J.; Pretty, J.; Robinson, S.; Thomas, S. M.; Toulmin, C. (2010): Food security: the challenge of feeding 9 billion people. In science 327 (5967), pp. 812-818. 
Goetz, S. J. (1992): A Selectivity Model of Household Food Marketing Behavior in Sub-Saharan Africa. In American Journal of Agricultural Economics 74 (2), pp. 444-452.

Govereh, J.; Jayne, T. S. (2003): Cash cropping and food crop productivity: synergies or trade-offs? In Agricultural Economics 28 (1), pp. 39-50.

Goyal, S. K.; Suhag, K. S.; Pandey, U. K. (2006): An Estimation of Technical Efficiency of Paddy Farmers in Haryana State of India. In Indian Journal of Agricultural Economics 61 (1), pp. 108-122.

Grabowski, R.; Pasurka, C. (1989): The Relative Efficiency of Slave Agriculture: An Application of a Stochastic Production Frontier. In Applied Economics 21 (5), pp. 587-595.

Groote, H. de; Owuor, G.; Doss, C.; Ouma, J.; Muhammad, L.; Danda, K. (2005): The maize green revolution in Kenya revisited. In Journal of Agricultural and Development Economics 2 (1), pp. 32-49.

Gruère, G.; Nagarajan, L.; King, E. (2009): The role of collective action in the marketing of underutilized plant species. Lessons from a case study on minor millets in South India. In Food Policy 34 (1), pp. 39-45.

Handschuch, C.; Wollni, M.; Villalobos, P. (2013): Adoption of food safety and quality standards among Chilean raspberry producers - Do smallholders benefit? In Food Policy 40, pp. 64-73.

Hoddinott, J.; Haddad, L. (1995): Does female income share influence household expenditures? Evidence from Côte d'Ivoire. In Oxford Bulletin of Economics and Statistics 57 (1), pp. 77-96.

IAASTD (2009): Agriculture at a Crossroads: Synthesis Report. Washington D. C., USA: Island Press.

IFAD (2010): Rural Poverty Report 2011. Rome, Italy: IFAD (International Fund for Agricultural Development).

Jha, R.; Rhodes, M. J. (1999): Some Imperatives of the Green Revolution: Technical Efficiency and Ownership of Inputs in Indian Agriculture. In Agricultural and Resource Economics Review 28 (1), pp. 57-64.

Kaganzi, E.; Ferris, S.; Barham, J.; Abenakyo, A.; Sanginga, P.; Njuki, J. (2009): Sustaining linkages to high value markets through collective action in Uganda. In Food Policy 34 (1), pp. 23-30.

Kaliba, A. R. M. (2004): Technical Efficiency of Smallholder Dairy Farms in Central Tanzania. In Quarterly Journal of International Agriculture 43 (1), pp. 39-55.

Kaliba, A. R. M.; Verkuijl, H.; Mwangi, W. (2000): Factors affecting adoption of improved maize seeds and use of inorganic fertilizer for maize production in the intermediate and lowland zones of Tanzania. In Journal of Agricultural and Applied Economics 32 (1), pp. 35-48.

Kennedy, E.; Reardon, T. (1994): Shift to non-traditional grains in the diets of East and West Africa: role of women's opportunity cost of time. In Food Policy 19 (1), pp. 45-56.

Kersting, S.; Wollni, M. (2012): New institutional arrangements and standard adoption. Evidence from small-scale fruit and vegetable farmers in Thailand. In Food Policy 37 (4), pp. 452-462.

Key, N.; Sadoulet, E.; de Janvry, A. (2000): Transactions Costs and Agricultural Household Supply Response. In American Journal of Agricultural Economics 82 (2), pp. 245-259.

Kilic, T.; Palacios-Lopez, A.; Goldstein, M. (2013): Caught in a productivity trap: a distributional perspective on gender differences in Malawian agriculture.

Kiriti, T. W.; Tisdell, C. (2003): Commercialisation of Agriculture in Kenya. Case Study of Policy Bias and Food Purchases by Farm Households. In Quarterly Journal of International Agriculture 42 (4), pp. 439-457. 
Knowler, D.; Bradshaw, B. (2007): Farmers' adoption of conservation agriculture: A review and synthesis of recent research. In Food Policy 32 (1), pp. 25-48.

Langyintuo, A. S.; Mungoma, C. (2008): The effect of household wealth on the adoption of improved maize varieties in Zambia. In Food Policy 33 (6), pp. 550-559.

Lukanu, G.; Green, J. M.; Worth, S. (2009): Aspects of Profitability That Influence Smallholder CashCrop Preferences in Northern Mozambique. In Development Southern Africa 26 (5), pp. 755777.

Maertens, M.; Swinnen, J. F. M. (2009): Trade, standards, and poverty. Evidence from Senegal. In World Development 37 (1), pp. 161-178.

Marenya, P. P.; Barrett, C. B. (2007): Household-level determinants of adoption of improved natural resources management practices among smallholder farmers in western Kenya. In Food Policy 32 (4), pp. 515-536.

Markelova, H.; Meinzen-Dick, R.; Hellin, J.; Dohrn, S. (2009): Collective action for smallholder market access. In Food Policy 34 (1), pp. 1-7.

Matuschke, I.; Qaim, M. (2008): Seed market privatisation and farmers' access to crop technologies: The case of hybrid pearl millet adoption in India. In Journal of Agricultural Economics 59 (3), pp. 498-515.

Matuschke, I.; Qaim, M. (2009): The impact of social networks on hybrid seed adoption in India. In Agricultural Economics 40 (5), pp. 493-505.

Meeusen, W.; van Den Broeck, J. (1977): Efficiency Estimation from Cobb-Douglas Production Functions with Composed Error. In International Economic Review 18 (2), pp. 435-444.

Mgonja, M. A.; Manyasa, E.; Kibuka, J.; Kaloki, P.; Nyaboke, S.; Wandera, G. (2007): Finger Millet in East Africa: Importance, Blast Disease Management and Promotion of Identified Blast Resistant Varieties in Western and Nyanza Provinces of Kenya. In Finger Millet Blast Management in East Africa: Creating opportunities for improving production and utilization of finger millet. Proceedings of the First International Finger Millet Stakeholder Workshop in Nairobi, Kenya; 13 - 14 September 2005, p. 49-65.

Mignouna, D. B.; Manyong, V. M.; Rusike, J.; Mutabazi, K. D. S.; Senkondo, E. M. (2011): Determinants of adopting Imazapyr-resistant maize technologies and its impact on household income in western Kenya. In AgBioForum 14 (3), pp. 158-163.

Mitaru, B. N.; Githiri, S. M. (2007): Priorities for Millet Research in East and Central Africa. In Finger Millet Blast Management in East Africa. Creating opportunities for improving production and utilization of finger millet, pp. 148-157.

Moser, C. M.; Barrett, C. B. (2003): The disappointing adoption dynamics of a yield-increasing, low external-input technology: the case of SRI in Madagascar. In Agricultural Systems 76 (3), pp. 1085-1100.

Narrod, C.; Roy, D.; Okello, J.; Avendaño, B.; Rich, K.; Thorat, A. (2009): Public-private partnerships and collective action in high value fruit and vegetable supply chains. In Food Policy 34 (1), pp. 8-15.

National Research Council (1996). Lost Crops of Africa: Volume I: Grains. Washington D. C., USA: The National Academies Press.

Nichola, T. (1996): The Decision to Adopt and the Intensity of Adoption of Technology: A Double Hurdle Model Application in the Adoption of a Sorghum Hybrid. In Journal for Studies in Economics and Econometrics 20, pp. 49-57. 
Njuki, J.; Kaaria, S.; Chamunorwa, A.; Chiuri, W. (2011): Linking Smallholder Farmers to Markets, Gender and Intra-household Dynamics: Does the Choice of Commodity Matter? In European Journal of Development Research 23 (3), pp. 426-443.

Nyende, P.; Tenywa, J. S.; Oryokot, J.; Kidoido, M. M. (2001): Weed profiles and management assessment for increased finger millet production in Uganda. In African Crop Science Journal 9 (3).

Oduori, C. (2005). The importance and research status of finger millet in Africa. Presented at the McKnight Foundation Collaborative Crop Research Program Workshop on Tef \& Finger Millet: Comparative Genomics of the Chloridoid Cereals at the Biosciences for East and Central Africa (BECA). Nairobi, Kenya, 28 - 30 June 2005.

Oduori, C. \& Kanyenji, B. (2007). Finger Millet in Kenya. Importance, Advances in R\&D, Challenges and Opportunities for Improved Production and Profitability. In Finger Millet Blast Management in East Africa: Creating opportunities for improving production and utilization of finger millet. Proceedings of the First International Finger Millet Stakeholder Workshop in Nairobi, Kenya; 13 - 14 September 2005, p. 10-22.

Ouma, E., Jagwe, J., Obare, G. A. \& Abele, S. (2010). Determinants of Smallholder Farmers' Participation in Banana Markets in Central Africa: The Role of Transaction Costs. Agricultural Economics 41 (2), pp. 111-122.

Pearce, R. (1990): Traditional food crops in sub-Saharan Africa: Potential and constraints. In Food Policy 15 (5), pp. 374-382.

Phillips, J. M.; Marble, R. P. (1986): Farmer education and efficiency: a frontier production function approach. In Economics of Education Review 5 (3), pp. 257-264.

Place, F.; Kariuki, G.; Wangila, J.; Kristjanson, P.; Makauki, A.; Ndubi, J. (2004): Assessing the factors underlying differences in achievements of farmer groups. methodological issues and empirical findings from the highlands of Central Kenya. In Agricultural Systems 82 (3), pp. 257-272.

Poulton, C.; Gibbon, P.; Hanyani-Mlambo, B.; Kydd, J.; Maro, W.; Larsen, M. et al. (2004): Competition and coordination in liberalized African cotton market systems. In World Development 32 (3), pp. 519-536.

Quisumbing, A. R. (1996): Male-female differences in agricultural productivity: Methodological issues and empirical evidence. In World Development 24 (10), pp. 1579-1595.

Quisumbing, A. R.; Pandolfelli, L. (2010): Promising approaches to address the needs of poor female farmers. Resources, constraints, and interventions. In World Development 38 (4), pp. 581592.

Rao, E. J. O.; Brümmer, B.; Qaim, M. (2012): Farmer Participation in Supermarket Channels, Production Technology, and Efficiency. The Case of Vegetables in Kenya. In American Journal of Agricultural Economics 94 (4), pp. 891-912.

Rao, E. J. O.; Qaim, M. (2011): Supermarkets, farm household income, and poverty. insights from Kenya. In World Development 39 (5), pp. 784-796.

Reardon, T.; Barrett, C. B.; Berdegué, J. A.; Swinnen, J. F. M. (2009): Agrifood industry transformation and small farmers in developing countries. In World Development 37 (11), pp. 1717-1727.

Rourke, B. E. (1974): Profitability of cocoa and alternative crops in Eastern Region, Ghana. In Economics of cocoa production and marketing, pp. 20-31.

Roy, D.; Thorat, A. (2008): Success in high value horticultural export markets for the small farmers. The case of Mahagrapes in India. In World Development 36 (10), pp. 1874-1890. 
Ruel, M. T. (2003): Operationalizing dietary diversity: a review of measurement issues and research priorities. In The Journal of nutrition 133 (11), pp. 3911S.

Saito, K. A.; Mekonnen, H.; Spurling, D. (1994): Raising the productivity of women farmers in SubSaharan Africa. Washington D. C., USA: World Bank Publications.

Sauer, J.; Tchale, H. (2009): The Economics of Soil Fertility Management in Malawi. In Applied Economic Perspectives and Policy 31 (3), pp. 535-560.

Schultz, T. W. (1964): Transforming traditional agriculture: New Haven, USA: Yale University Press.

Shiferaw, B.; Obare, G.; Muricho, G. (2008): Rural market imperfections and the role of institutions in collective action to improve markets for the poor. In Natural Resources Forum 32, pp. 25-38.

Simtowe, F.; Zeller, M.; Diagne, A. (2009): The impact of credit constraints on the adoption of hybrid maize in Malawi. In Review of Agricultural and environmental studies 90 (1), pp. 5-22.

Sserunkuuma, D. (2005): The adoption and impact of improved maize and land management technologies in Uganda. In Electronic Journal of Agricultural and Development Economics 2 (1), pp. 67-84.

Stata Press (2007). Stata User's Guide, Release 10. College Station, USA: Stata Press.

Taylor, T. G.; Scott Shonkwiler, J. (1986): Alternative stochastic specifications of the frontier production function in the analysis of agricultural credit programs and technical efficiency. In Journal of Development Economics 21 (1), pp. 149-160.

Tchakounte, R.; Noula, A. G.; Ngassam, S. B. (2012): The Determinants of the Technical Efficiency of Cotton Farmers in Northern Cameroon. In International Journal of Economics 6 (2), pp. 213223.

Thirtle, C.; Lin, L.; Piesse, J. (2003): The impact of research-led agricultural productivity growth on poverty reduction in Africa, Asia and Latin America. In World Development 31 (12), pp. 19591975.

TISA (2013): Kenya's 47 Counties. Available online at http://www.tisa.or.ke/countdown-tocounties/kenyas-47-counties/, checked on 9/5/2013.

Udry, C. R. (1996): Gender, agricultural production, and the theory of the household. In Journal of political Economy, pp. 1010-1046.

UNDP (2013): The Millennium Development Goals Report. New York, USA: The United Nations.

von Braun, J. (1995): Agricultural commercialization. impacts on income and nutrition and implications for policy. In Food Policy 20 (3), pp. 187-202.

Welch, R. M.; Graham, R. D. (1999): A new paradigm for world agriculture: meeting human needs: Productive, sustainable, nutritious. In Field Crops Research 60 (1-2), pp. 1-10.

Wollni, M.; Brümmer, B. (2012): Productive Efficiency of Specialty and Conventional Coffee Farmers in Costa Rica: Accounting for Technological Heterogeneity and Self-Selection. In Food Policy 37 (1), pp. 67-76.

Wollni, M.; Lee, D. R.; Thies, J. E. (2010): Conservation agriculture, organic marketing, and collective action in the Honduran hillsides. In Agricultural Economics 41 (3-4), pp. 373-384.

Wooldridge, J. M. (2009). Introductory econometrics: A modern approach. Fourth Edition. SouthWestern: Cengage Learning.

Wu, B.; Pretty, J. (2004): Social connectedness in marginal rural China: The case of farmer innovation circles in Zhidan, north Shaanxi. In Agriculture and Human values 21 (1), pp. 81-92. 
Zeller, M.; Diagne, A.; Mataya, C. (1998): Market access by smallholder farmers in Malawi. Implications for technology adoption, agricultural productivity and crop income. In Agricultural Economics 19 (1-2), pp. 219-229. 


\section{Annex A: Additional tables}

Table A 3: First stage results of the FIML Heckman selection model

\begin{tabular}{lrlr} 
& Coefficient & Standard Error \\
\hline Millet group & .974 & $* * *$ & .210 \\
Female crop & .371 & $*$ & .198 \\
Maize marketing & .662 & $* * *$ & .203 \\
Age head & -.007 & .008 \\
Education head & -.130 & .215 \\
Household size & .023 & .035 \\
Housing index & -.306 & $* * *$ & .113 \\
Cell phone & .320 & .305 \\
Radio & -.035 & .257 \\
Transport & .109 & .307 \\
Market distance & -.002 & .005 \\
Mumias & -.290 & .254 \\
Teso & -.246 & .234 \\
Constant & .299 & .681 \\
\hline
\end{tabular}


Table A 4: Variables used in efficiency model

\begin{tabular}{|c|c|c|c|c|c|}
\hline Variable & Variable description & Mean & Std. Dev. & Mean & Std. Dev. \\
\hline & & \multicolumn{2}{|c|}{ Finger millet } & \multicolumn{2}{|c|}{ Maize } \\
\hline Harvest (In) & Logarithm of quantity harvested (kg) & 4.830 & 1.382 & 6.127 & 1.193 \\
\hline Seeds (In) & Logarithm of seed quantity (kg) & .974 & .834 & 1.951 & .747 \\
\hline Fertilizer (In) & Logarithm of chemical fertilizer quantity (kg) & 1.613 & 1.858 & 2.289 & 2.089 \\
\hline Labor (In) & Logarithm of work input (days) & 4.140 & .780 & 4.325 & .650 \\
\hline Cropping area (In) & Logarithm of cropping area (acres) & -.531 & .794 & .084 & .700 \\
\hline Zero fertilizer & $1=$ No use of chemical fertilizer & .467 & .500 & .389 & .488 \\
\hline $\begin{array}{l}\text { Ox plough / } \\
\text { tractor }\end{array}$ & $1=$ Use of an ox-plough or tractor & .504 & .501 & .563 & .497 \\
\hline Early sowing & 1= Planted between December and March & .578 & .495 & .304 & .461 \\
\hline Modern variety & $1=$ Use of a modern variety & .491 & .498 & .719 & .448 \\
\hline Organic fertilizer & $1=$ Use of organic fertilizer & .337 & .474 & .478 & .500 \\
\hline Soil fertility & 1= High soil fertility (plot specific) & .296 & .457 & .226 & .419 \\
\hline Female crop & $1=$ Crop is cultivated by a woman & .493 & .501 & .444 & .498 \\
\hline Variable & Variable description & & Mean & & Std. Dev. \\
\hline Altitude & Altitude of dwelling (meters) & & 4131.137 & & 291.236 \\
\hline $\begin{array}{l}\text { Group } \\
\text { membership }\end{array}$ & Number of village group memberships & & 1.848 & & 1.239 \\
\hline Head age & Age of the household head (years) & & 54.468 & & 13.449 \\
\hline Adults & Number of adults in the household & & 3.496 & & 1.767 \\
\hline Farm size & Farm size (acres) & & 3.973 & & 3.978 \\
\hline Cell phone & $1=$ Ownership of a cell phone & & .848 & & .360 \\
\hline $\begin{array}{l}\text { Secondary } \\
\text { education }\end{array}$ & $\begin{array}{l}\text { 1= At least one household member with } \\
\text { secondary education }\end{array}$ & & .496 & & .501 \\
\hline Agenga_ext & $1=$ Farm is located in Agenga & & .067 & & .250 \\
\hline Amagoro_ext & 1= Farm is located in Amagoro & & .067 & & .250 \\
\hline Budwanga_ext & $1=$ Farm is located in Budwanga & & .067 & & .250 \\
\hline Angurai & $1=$ Farm is located in Angurai & & .067 & & .250 \\
\hline Asinge & $1=$ Farm is located in Asinge & & .067 & & .250 \\
\hline Busibwabo & 1= Farm is located in Busibwabo & & .067 & & .250 \\
\hline Elugulu & $1=$ Farm is located in Elugulu & & .067 & & .250 \\
\hline Kaliwa & $1=$ Farm is located in Kaliwa & & .067 & & .250 \\
\hline Kotur & $1=$ Farm is located in Kotur & & .067 & & .250 \\
\hline Matungu & 1= Farm is located in Matungu & & .133 & & .341 \\
\hline Nambale & 1= Farm is located in Nambale & & .067 & & .250 \\
\hline Ochude & $1=$ Farm is located in Ochude & & .067 & & .250 \\
\hline
\end{tabular}




\section{Annex B: Household questionnaire}

Thank you very much for agreeing on participating in this household survey. We are researchers from the University of Göttingen in Germany in collaboration with ICRISAT (International Crops Research Institute for the Semi-Arid Tropics) in Nairobi and KARI (Kenyan Agricultural Research Institute) in Kakamega and Alupe.

KARI and ICRISAT are currently running a research project on finger millet production and finger millet marketing. This survey has the purpose of learning more about the production and marketing practices of finger millet farmers like you. The information that we get in this survey will help us to understand the problems of finger millet production and marketing and to implement projects that can improve the production and marketing possibilities for finger millet in this region.

We respect all answers you give and want to remind you that there are no right or wrong answers. If you have any questions, please address them to the interviewer. All your answers will be treated as confidential.

\section{Interview}

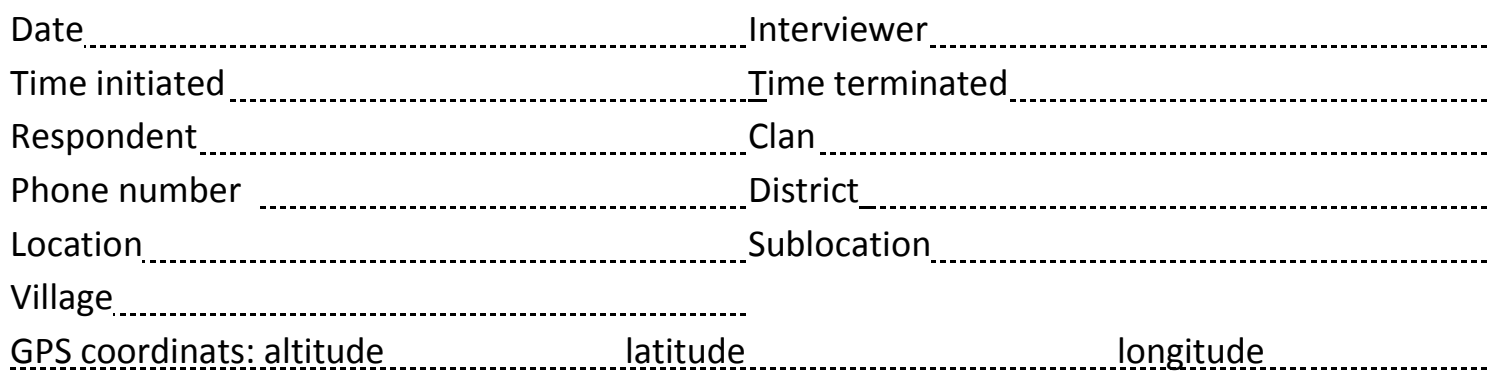

(Geographic latitude and longitude, NOT projected coordinates) 


\section{Basic household characteristics}

a) Distance to the village market $(\mathrm{km})$

b) Distance to the nearest main market $(\mathrm{km})$

c) Main household language:

d) Main household religion:

e) When did the household form (year)

f) Does the household originate in this village? No( $) 0 \quad$ yes ( )1

g) If the answer to f) is 'no', when did the household arrive in this village? (year).

h) Has this household ever participated in a farm household survey before?

i) No( $) 0 \quad$ yes ( $) 1$

j) If the answer to i) is 'yes', in how many household surveys did the household participate before?

k) Did you grow finger millet in 2011? No ( )0 Yes ( )1

- If the answer to k) is 'no', stop the interview here!

minutes of walking time minutes of walking time 


\section{The household}

Please give us some information on the members of the household.

The household is defined as all the people usually living together in this dwelling and sharing expenses.

\section{Table 3.1: Household members}
Column 1:
Column 2:
List names of all individuals in household (List household head first, use first names only)
Column 3:
Column 4:
Column 5:
What is "
'"'s relationship to household head? (e.g. son, daughter, father, mother, stepson, stepdaughter)
Gender (male $=1$, female $=2$ )
How old is "
"? (years)
Column 7:
Main occupation (if the hh member is still a student, skip Columns $6-8$ ) years of education

Column 8: $\quad$ highest educational level

\begin{tabular}{|c|c|c|c|c|c|c|c|c|}
\hline $\begin{array}{l}\text { household } \\
\text { member code }\end{array}$ & Column 1 & Column 2 & Column 3 & Column 4 & Column 5 & Column 6 & Column 7 & Column 8 \\
\hline \multicolumn{9}{|l|}{ hh01 } \\
\hline \multicolumn{9}{|l|}{ hh02 } \\
\hline \multicolumn{9}{|l|}{ hh03 } \\
\hline \multicolumn{9}{|l|}{ hh04 } \\
\hline \multicolumn{9}{|l|}{ hh05 } \\
\hline \multicolumn{9}{|l|}{ hh06 } \\
\hline \multicolumn{9}{|l|}{ hh07 } \\
\hline \multicolumn{9}{|l|}{ hh08 } \\
\hline \multicolumn{9}{|l|}{ hh09 } \\
\hline \multicolumn{9}{|l|}{ hh10 } \\
\hline \multicolumn{9}{|l|}{ hh11 } \\
\hline \multicolumn{9}{|l|}{ hh12 } \\
\hline \multicolumn{9}{|l|}{ hh13 } \\
\hline \multicolumn{9}{|l|}{ hh14 } \\
\hline \multicolumn{9}{|l|}{ hh15 } \\
\hline \multicolumn{9}{|l|}{ hh16 } \\
\hline hh17 & & & & & & & & \\
\hline
\end{tabular}

What is the marital status of the household head?

Married, living with spouse

Divorced/separated

Never married
)1

13

$\lcm{5}$
Married, spouse away for more than 6 months / year $\quad(\quad 12$
Widow/widower

Widow/widower 


\section{Participation in groups}

In this section, we would like to know about your household's participation in social groups. These groups might be registered or not registered; they might be church groups, women groups, self-help groups, farmer groups etc. Please list all the groups in which at least one of your household members participates.

\section{Table 4.1: Groups and group characteristics}

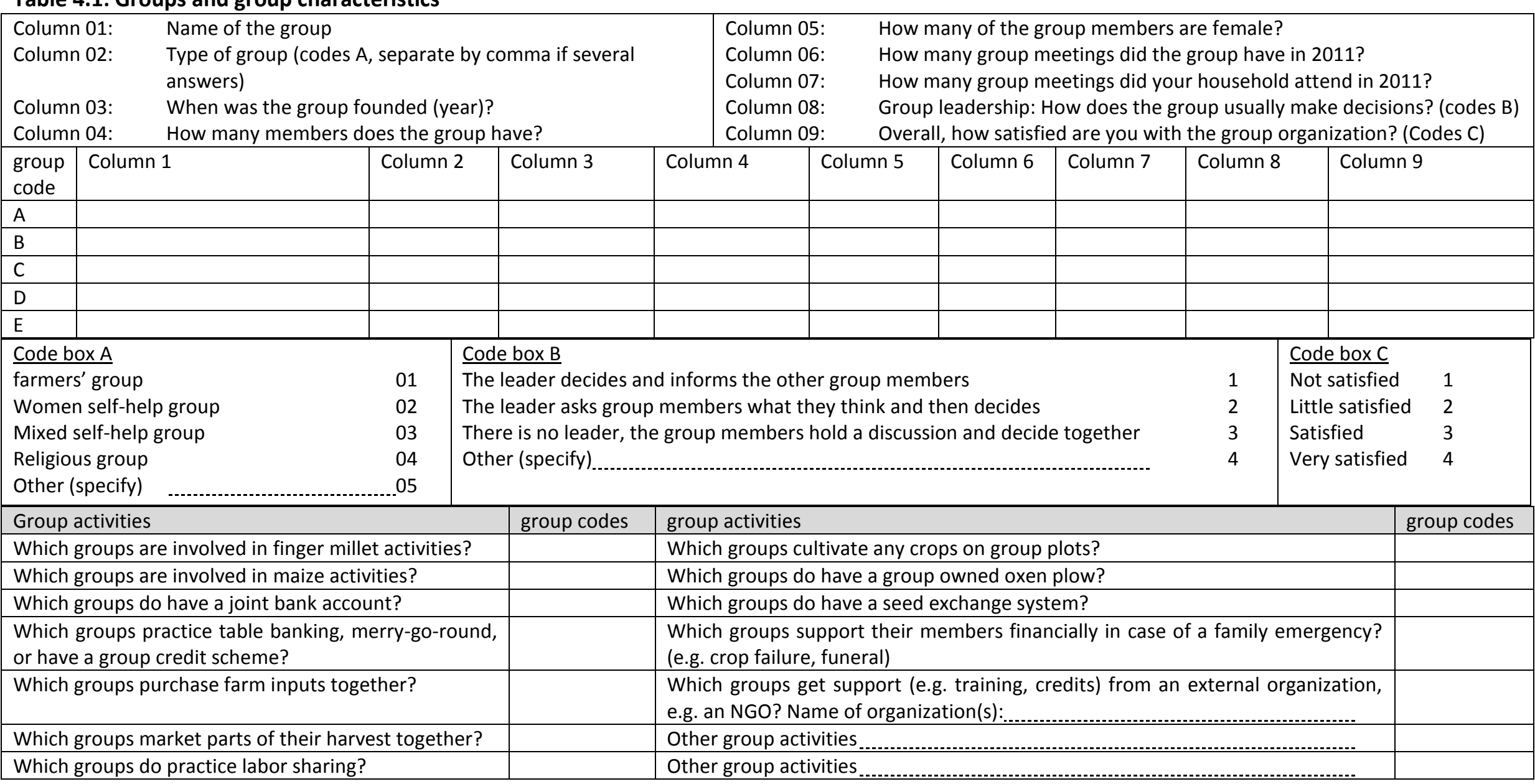


In table 4.2, we would like to know more about your own participation in the groups you mentioned. To identify the groups, please use the group codes from Table 4.1.

\section{Table 4.2: Household's participation in the group}

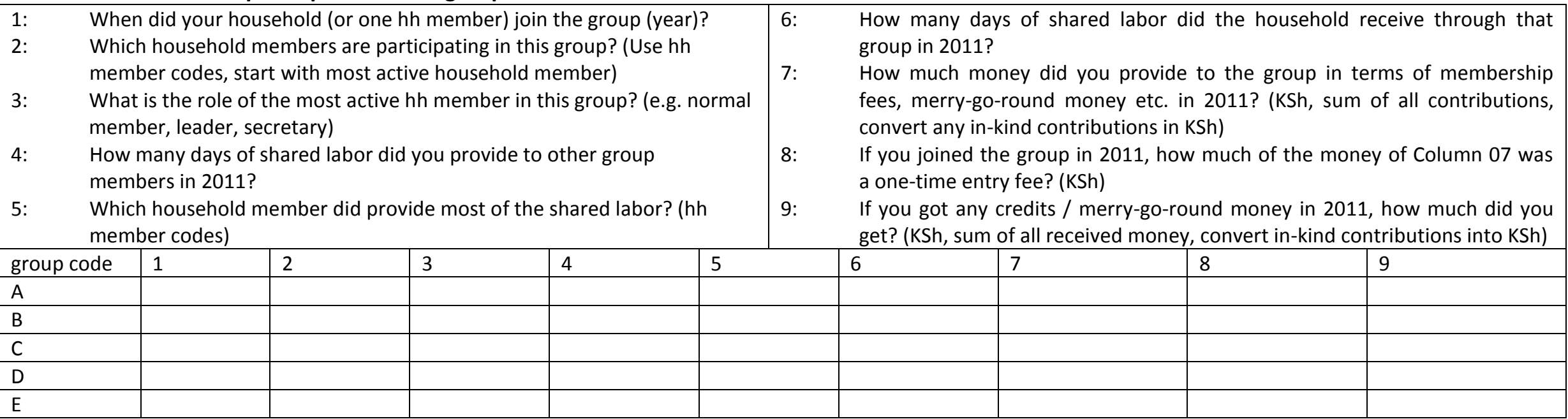

Finally, we would like to know about your motivation to join a group and whether these expectations were fulfilled or not by the different groups.

Table 4.3: Motivations to join a group

\begin{tabular}{|c|c|c|}
\hline group code & What were your main motivations to join this group? & $\begin{array}{l}\text { Were your } \\
\text { expectations } \\
\text { fulfilled? (Codes A) }\end{array}$ \\
\hline \multicolumn{3}{|l|}{ A } \\
\hline \multicolumn{3}{|l|}{ B } \\
\hline \multicolumn{3}{|l|}{$\mathrm{C}$} \\
\hline \multicolumn{3}{|l|}{$\mathrm{D}$} \\
\hline \multicolumn{3}{|l|}{$\mathrm{E}$} \\
\hline Codes A: & yes, partly = 1 & \\
\hline
\end{tabular}

a) Are you practicing any labor sharing outside of groups, e.g. with one of your neighbors?
No
yes
1
(if no, skip questions e) and f))

b) How many days of shared labor did you provide in 2011 outside of any groups?

c) How many days of shared labor did you receive in 2011 outside of any groups? 


\section{Contact to other finger millet farmers}

In this table, we would like you to name the 3 finger millet farmers that you are in closest contact with.

\section{Table 5.1: Contact to other farmers}

\section{1: Name of the farmer}

02: Gender of the farmer (male $=1$, female $=2$ )

03: Does the farmer stay in your village? $(\mathrm{no}=0$, yes $=1)$

04: Relationship with the farmer (Codes A)

05: Is this farmer a member in any of the groups that you participate in? (no=0; yes $=1$ )

06: If the answer in Column 5 is yes, in which group is the farmer a member? (use group codes from table 3.1)

07: How often do you talk to that farmer? (code box B)

08: Do you observe this farmer's finger millet cropping practices? (Code box $\mathrm{C}$ )

09: Do you discuss your finger millet cropping practices with this farmer? (code box $\mathrm{C}$ )

10: Have you ever tried a new input (e.g. a new variety), or adopted a new production method in finger millet production because of your observations on his / her plot? (no=0; yes=1)

11: Have you ever tried a new input (e.g. a new variety) or adopted a new production method in finger millet production because of your discussions with this farmer? (no=0; yes=1)

12: If he/she gave you an advice today, would you trust his/her advice? (code box D)

13: If you needed to borrow some money and this farmer was able to lend you this money, would he/she do so? (code box D)

14: If this farmer asked you to borrow some money from you and you were able to lend him this money, would you do so? (code box D)

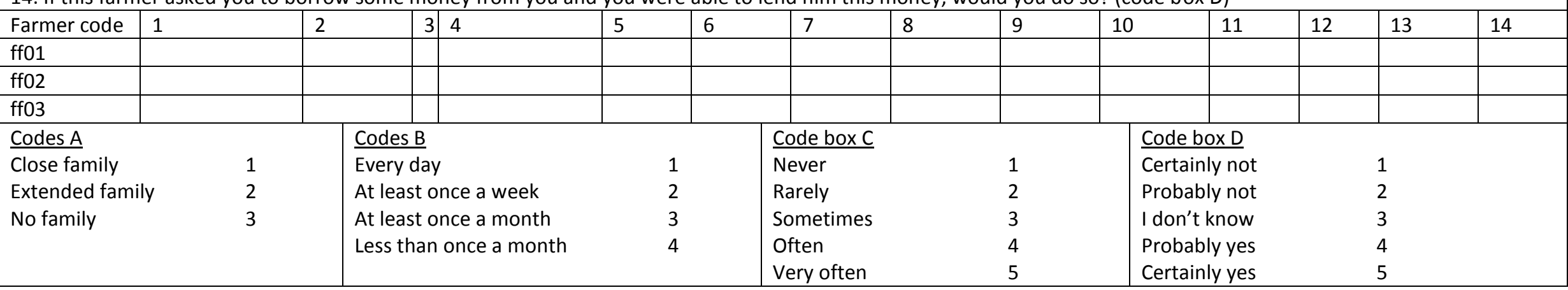

a) Have you ever tried a new finger millet practice / input because of observations on another farmers plot?

No $(\quad) 0$

yes $\quad$ )1

b) If yes, which practices / inputs did you try?

c) Have you ever tried a new finger millet practice / input because of discussions with another farmer?

No $(\quad) 0$

yes ( )1

d) If yes, which practices / inputs did you try? 


\section{Crop- and pasture land}

Please list all cropping (sub)plots and pasture areas of the household. This includes all plots that are cultivated by the household itself, fallow plots, and plots that are rented out or borrowed to other farmers by the household. Start with the largest plot.

Definitions: A plot is a piece of land physically separated from others; a subplot is a subunit of a plot. If you divided a plot into several sub-plots (with different crops grown on the different subplots), then list each subplot in a separate column.

\section{Table 6.1: Cropland- and pasture land}

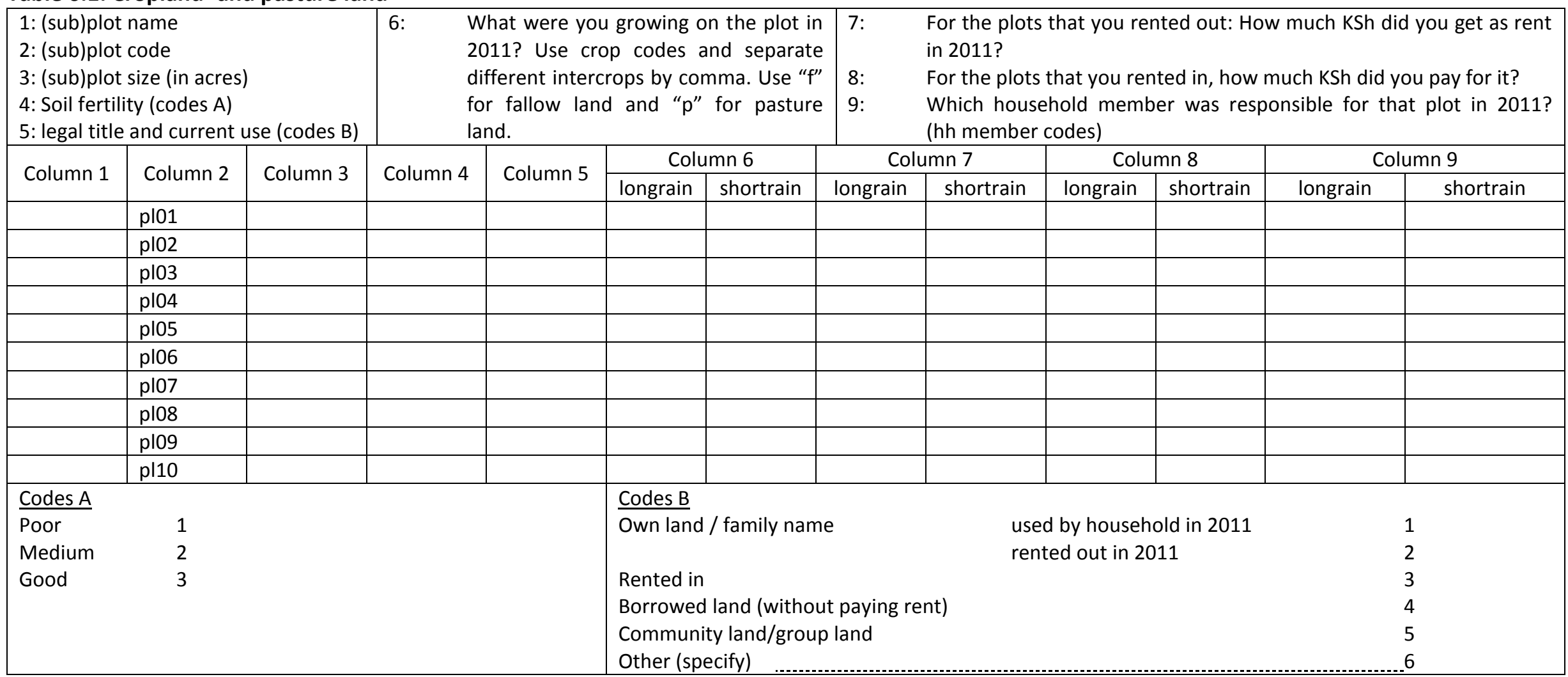

Table 6.2: Fruit trees; If you have any fruit trees on your land, please list them in Table 6.2

\begin{tabular}{|l|l|l|l|l|l|l|}
\hline Name of fruit tree & Number of trees & Name of fruit tree & Number of trees & Name of fruit tree & Number of trees & Name of fruit tree \\
\hline & & & & & & \\
\hline
\end{tabular}




\section{Cropping practices}

Now I would like to have some details on your cropping practices. In Table 7.1, please list all (sub) plots on which you were cultivating finger millet and maize in 2011 and give some information on your activities concerning soil preparation, planting, weeding, and harvesting on those plots.

Table 7.1: Basic cropping practices for finger millet and maize

\begin{tabular}{|c|c|c|c|c|c|c|c|c|c|c|c|c|c|c|c|c|c|c|}
\hline \multirow{3}{*}{$\begin{array}{l}\text { Plot } \\
\text { code }\end{array}$} & \multicolumn{5}{|c|}{ Soil preparation } & \multicolumn{8}{|c|}{ Sowing / planting } & \multicolumn{5}{|c|}{ Weeding / Thinning } \\
\hline & \multirow{2}{*}{$\begin{array}{c}\text { start } \\
\text { (month) }\end{array}$} & \multicolumn{4}{|c|}{ labor input (days) ${ }^{31}$} & \multirow[t]{2}{*}{ crop code ${ }^{32}$} & \multirow{2}{*}{ start (month) } & \multicolumn{2}{|c|}{ quantity } & \multicolumn{4}{|c|}{ labor input (days) } & \multirow{2}{*}{ start (month) } & \multicolumn{4}{|c|}{ labor input (days) } \\
\hline & & 1 & $\begin{array}{c}2 \\
33\end{array}$ & 3 & 4 & & & No. & Unit code & 1 & 2 & 3 & 4 & & 1 & 2 & 3 & 4 \\
\hline \multicolumn{19}{|c|}{ Longrain } \\
\hline & & & & & & & & & & & & & & & & & & \\
\hline & & & & & & & & & & & & & & & & & & \\
\hline & & & & & & & & & & & & & & & & & & \\
\hline & & & & & & & & & & & & & & & & & & \\
\hline & & & & & & & & & & & & & & & & & & \\
\hline & & & & & & & & & & & & & & & & & & \\
\hline \multicolumn{19}{|c|}{ Shortrain } \\
\hline & & & & & & & & & & & & & & & & & & \\
\hline & & & & & & & & & & & & & & & & & & \\
\hline & & & & & & & & & & & & & & & & & & \\
\hline & & & & & & & & & & & & & & & & & & \\
\hline & & & & & & & & & & & & & & & & & & \\
\hline & & & & & & & & & & & & & & & & & & \\
\hline
\end{tabular}

\section{Note: Additional sheets are provided for farms with more plots!}

\section{Table 7.1: Basic cropping practices for finger millet and maize}

\begin{tabular}{|c|c|c|c|c|c|c|c|c|}
\hline \multirow{2}{*}{$\begin{array}{l}\text { Plot } \\
\text { code }\end{array}$} & \multicolumn{4}{|c|}{ application of chemical fertilizer } & \multicolumn{4}{|c|}{ application of pesticides } \\
\hline & Product & Quantity & start (month) & labor input (days) & Product & Quantity & start (month) & labor input (days) \\
\hline
\end{tabular}

31 The labor input is calculated in man-days. Ex.: If 3 persons worked on a plot for 2 days, the labor input is $3 * 2=6$.

${ }^{32}$ Please list the crop codes for all crops that were intercropped with maize or millet on that plot. In the case of maize and finger millet, please add the variety name in brackets.

${ }^{33}$ If several hh members provided the same amount of labor input, put a footnote $(a, b, c, d, \ldots)$ to list all of them on the bottom of this page 


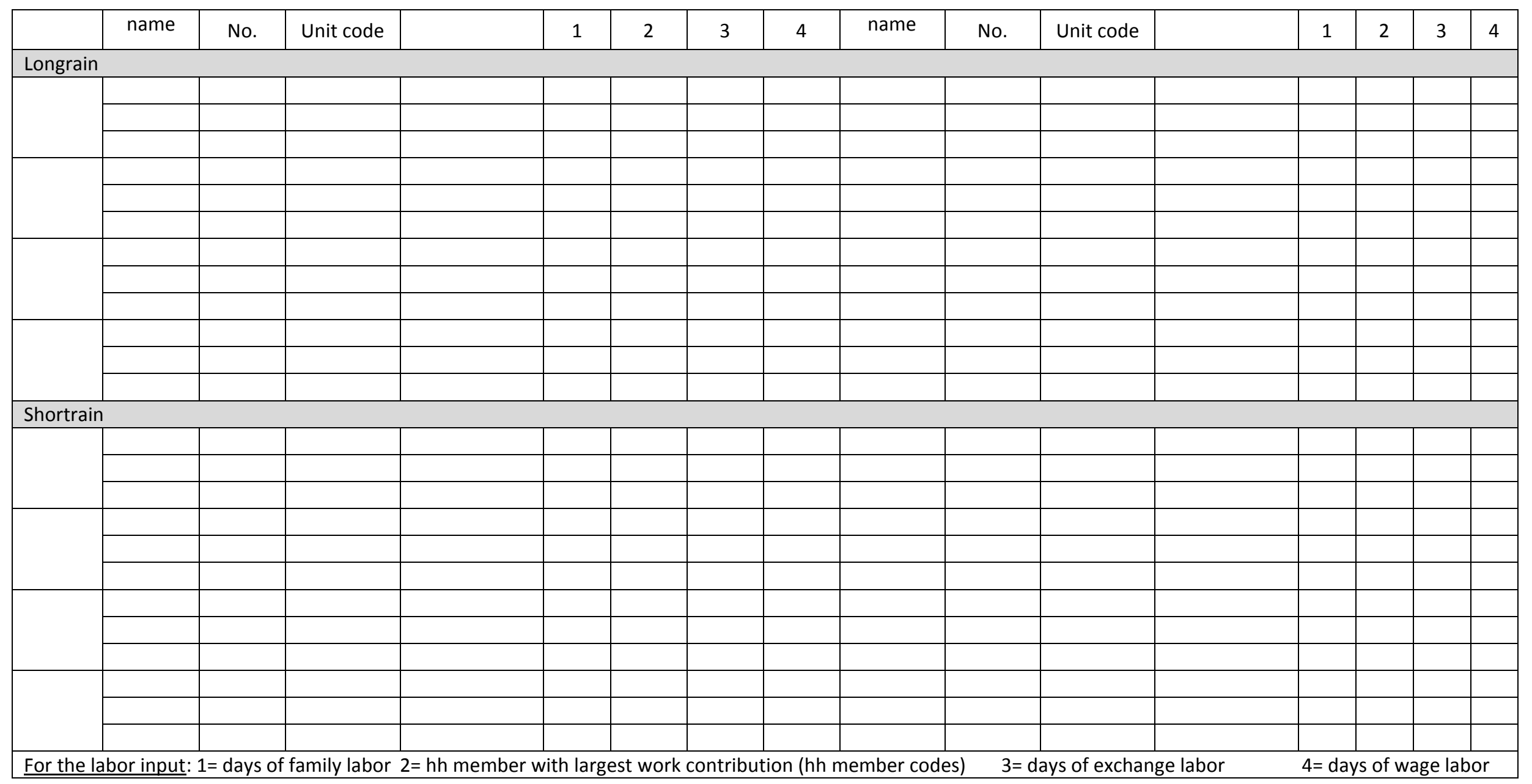


Table7.1: Basic cropping practices for finger millet and maize

\begin{tabular}{|c|c|c|c|c|c|c|c|c|c|c|c|c|c|c|c|}
\hline \multirow{3}{*}{$\begin{array}{l}\text { Plot } \\
\text { code }\end{array}$} & \multicolumn{8}{|c|}{ application of manure } & \multicolumn{7}{|c|}{ Harvesting } \\
\hline & \multirow{2}{*}{$\begin{array}{l}\text { Type of } \\
\text { manure }\end{array}$} & \multicolumn{2}{|c|}{ Quantity } & \multirow{2}{*}{$\begin{array}{c}\text { start } \\
\text { (month) }\end{array}$} & \multicolumn{4}{|c|}{ Labor input (days) } & \multicolumn{2}{|c|}{ Quantity harvested } & \multirow{2}{*}{ start (month) } & \multicolumn{4}{|c|}{ Labor input (days) } \\
\hline & & No. & Unit code & & 1 & 2 & 3 & 4 & No. & Unit code & & 1 & 2 & 3 & 4 \\
\hline \multicolumn{16}{|c|}{ Longrain } \\
\hline & & & & & & & & & & & & & & & \\
\hline & & & & & & & & & & & & & & & \\
\hline & & & & & & & & & & & & & & & \\
\hline & & & & & & & & & & & & & & & \\
\hline & & & & & & & & & & & & & & & \\
\hline & & & & & & & & & & & & & & & \\
\hline & & & & & & & & & & & & & & & \\
\hline & & & & & & & & & & & & & & & \\
\hline & & & & & & & & & & & & & & & \\
\hline & & & & & & & & & & & & & & & \\
\hline & & & & & & & & & & & & & & & \\
\hline & & & & & & & & & & & & & & & \\
\hline \multicolumn{16}{|c|}{ Shortrain } \\
\hline & & & & & & & & & & & & & & & \\
\hline & & & & & & & & & & & & & & & \\
\hline & & & & & & & & & & & & & & & \\
\hline & & & & & & & & & & & & & & & \\
\hline & & & & & & & & & & & & & & & \\
\hline & & & & & & & & & & & & & & & \\
\hline & & & & & & & & & & & & & & & \\
\hline & & & & & & & & & & & & & & & \\
\hline & & & & & & & & & & & & & & & \\
\hline & & & & & & & & & & & & & & & \\
\hline & & & & & & & & & & & & & & & \\
\hline & & & & & & & & & & & & & & & \\
\hline
\end{tabular}

You have given detailed answers on your maize and finger millet production in table 7.1. In Table 7.2, we would like to have some information on your other crops. Please list the plots on which you did not cultivate finger millet or maize in 2011. Important: If there are plots that you did only mention for either the longrain or the shortrain period in the previous table, you will need to mention them for the other cropping period in this table. 
Table 7.2: Cropping calendar for other crops

\begin{tabular}{|c|c|c|c|c|c|c|c|c|c|c|c|c|c|c|c|c|c|}
\hline \multirow{3}{*}{$\begin{array}{l}\text { Plot } \\
\text { code }\end{array}$} & \multicolumn{2}{|c|}{ Soil preparation } & \multicolumn{3}{|c|}{ Sowing / planting } & \multicolumn{2}{|c|}{$\begin{array}{c}\text { Weeding / } \\
\text { Thinning / } \\
\text { cutting of trees } \\
\end{array}$} & \multicolumn{5}{|c|}{$\begin{array}{l}\text { Application of chemical fertilizer } \\
\text { Application of pesticides } \\
\text { Application of manure }\end{array}$} & \multicolumn{5}{|c|}{ Harvesting } \\
\hline & \multirow{2}{*}{$\begin{array}{c}\text { start } \\
\text { (month) }\end{array}$} & \multirow{2}{*}{$\begin{array}{l}\text { labor } \\
\text { input } \\
\text { (days) }\end{array}$} & \multirow{2}{*}{$\begin{array}{l}\text { crop } \\
\text { code }\end{array}$} & \multirow{2}{*}{$\begin{array}{c}\text { start } \\
\text { (month) }\end{array}$} & \multirow{2}{*}{$\begin{array}{l}\text { Labor } \\
\text { input } \\
\text { (days) }\end{array}$} & \multirow{2}{*}{$\begin{array}{c}\text { start } \\
\text { (month) }\end{array}$} & \multirow{2}{*}{$\begin{array}{l}\text { labor } \\
\text { input } \\
\text { (days) }\end{array}$} & \multirow{2}{*}{$\begin{array}{l}\text { Product } \\
\text { name }\end{array}$} & \multicolumn{2}{|c|}{ quantity } & \multirow{2}{*}{$\begin{array}{l}\text { Labor } \\
\text { input } \\
\text { (days) }\end{array}$} & \multirow{2}{*}{$\begin{array}{c}\text { Start } \\
\text { (month) }\end{array}$} & \multirow{2}{*}{$\begin{array}{l}\text { Crop } \\
\text { code }\end{array}$} & \multirow{2}{*}{$\begin{array}{c}\text { Start } \\
\text { (month) }\end{array}$} & \multirow{2}{*}{$\begin{array}{l}\text { Labor } \\
\text { input } \\
\text { (days) }\end{array}$} & \multicolumn{2}{|c|}{ Quantity harvested } \\
\hline & & & & & & & & & No. & $\begin{array}{l}\text { Unit } \\
\text { code }\end{array}$ & & & & & & No. & Unit code \\
\hline \multicolumn{18}{|c|}{ Longrain } \\
\hline & & & & & & & & & & & & & & & & & \\
\hline & & & & & & & & & & & & & & & & & \\
\hline & & & & & & & & & & & & & & & & & \\
\hline & & & & & & & & & & & & & & & & & \\
\hline & & & & & & & & & & & & & & & & & \\
\hline & & & & & & & & & & & & & & & & & \\
\hline & & & & & & & & & & & & & & & & & \\
\hline & & & & & & & & & & & & & & & & & \\
\hline & & & & & & & & & & & & & & & & & \\
\hline & & & & & & & & & & & & & & & & & \\
\hline & & & & & & & & & & & & & & & & & \\
\hline \multicolumn{18}{|c|}{ Shortrain } \\
\hline & & & & & & & & & & & & & & & & & \\
\hline & & & & & & & & & & & & & & & & & \\
\hline & & & & & & & & & & & & & & & & & \\
\hline & & & & & & & & & & & & & & & & & \\
\hline & & & & & & & & & & & & & & & & & \\
\hline & & & & & & & & & & & & & & & & & \\
\hline & & & & & & & & & & & & & & & & & \\
\hline & & & & & & & & & & & & & & & & & \\
\hline & & & & & & & & & & & & & & & & & \\
\hline & & & & & & & & & & & & & & & & & \\
\hline & & & & & & & & & & & & & & & & & \\
\hline
\end{tabular}




\section{Origin of inputs}

In this section, we would like to know more about your procurement of inputs in 2011.

For the seeds / planting material: List all seeds and planting material that does not come from the farm. Use crop codes, add variety names in brackets for finger millet and maize.

For the pesticides / fertilizer: Write name of product.

For the manure: List only manure that does not come from your own farm, write down the type of manure.

Table 8.1: Procurement of inputs

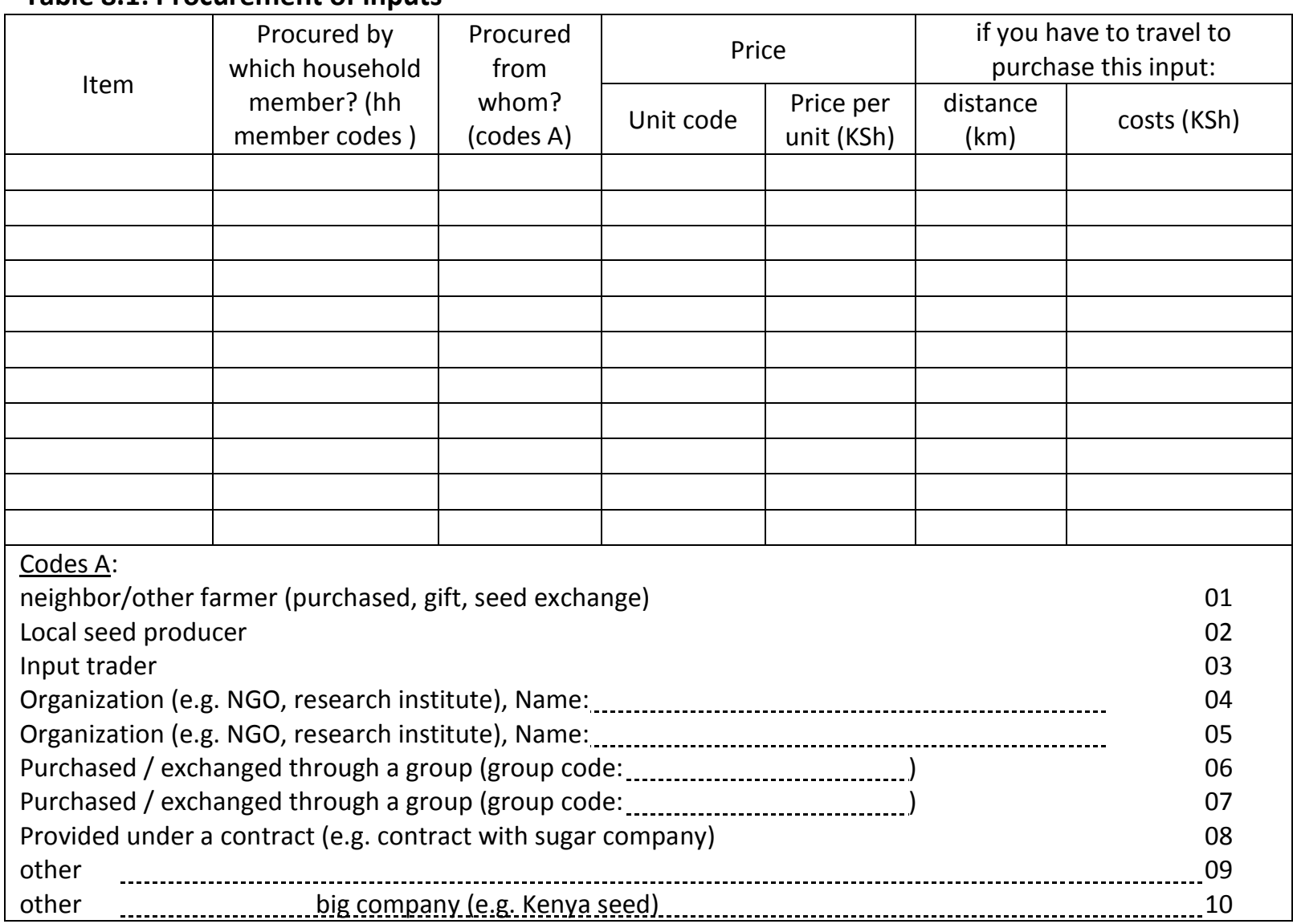

If you used an ox or a tractor for any of your cropping activities, please specify in Table 8.2

Table 8.2: Use of oxen /tractors

\begin{tabular}{|c|c|c|c|c|c|}
\hline & $\begin{array}{l}\text { Used on which } \\
\text { plots? (plot codes) }\end{array}$ & $\begin{array}{l}\text { Used when? } \\
\text { (months) }\end{array}$ & $\begin{array}{l}\text { Used for how } \\
\text { many days? }\end{array}$ & $\begin{array}{l}\text { Accessed how? } \\
\text { (Codes A) }\end{array}$ & daily costs (KSh) \\
\hline \multicolumn{6}{|l|}{ Ox } \\
\hline \multicolumn{6}{|l|}{ Tractor } \\
\hline \multicolumn{6}{|l|}{ Codes A: } \\
\hline \multicolumn{5}{|c|}{ 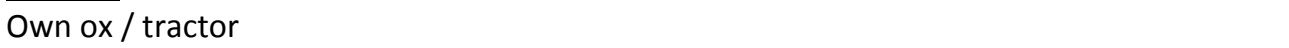 } & 01 \\
\hline \multicolumn{5}{|c|}{ Borrowed from individual } & 02 \\
\hline \multicolumn{5}{|c|}{ Borrowed through a group } & 03 \\
\hline \multicolumn{5}{|c|}{ Provided under a contract (e.g. contract with sugar company) } & 04 \\
\hline \multicolumn{5}{|l|}{ other } & 05 \\
\hline
\end{tabular}

Do you irrigate parts of your land? $\quad$ No ( ) 0 yes ( )1

If yes: On which plots (plot codes:

), which type of irrigation system

costs in

2011 (KSh)

In total, how many days of wage labor did you use in 2011?

On average, how much did you pay for one day of wage labor in 2011? (KSh) 


\section{Finger millet cropping practices and constraints}

\section{Table 9.1: Finger millet cropping practices}

\begin{tabular}{|c|c|c|c|c|c|c|}
\hline $\begin{array}{ll}\text { Column 1: } & \mathrm{Ha} \\
\text { Column 2: } & \mathrm{Ha} \\
\text { Column 3: } & \text { Do } \\
\text { Column 4: } & \text { Fo } \\
\text { Column 5: } & \text { Wr } \\
\text { Column 6: } & \text { Wr }\end{array}$ & $\begin{array}{l}\text { you ever o } \\
\text { you ever le } \\
\text { ou apply thi } \\
\text { ow many y } \\
\text { are the rea } \\
\text { are the rea }\end{array}$ & $\begin{array}{l}\text { erved this } \\
\text { ned more } \\
\text { ractice in } \\
\text { rs have you } \\
\text { ons for you } \\
\text { ns for you }\end{array}$ & $\begin{array}{l}\text { actice in fi } \\
\text { bout this pr } \\
\text { oger millet } \\
\text { applied this } \\
\text { o apply thi } \\
\text { ot to apply }\end{array}$ & $\begin{array}{l}\text { ger millet } p \\
\text { ctice in fin } \\
\text { roduction? } \\
\text { practice? } \\
\text { practice? } \\
\text { this practic }\end{array}$ & $\begin{array}{l}\text { uction? }(\mathrm{No}=0 ; \text { yes }=1) \\
\text { millet production through training / field days } \\
\mathrm{D}=0 ; \text { Yes }=1 ; \text { Not anymore }=2 \text { ) } \\
\text { ribe its main objectives and advantages. } \\
\text { Describe its main disadvantages. }\end{array}$ & tension services etc.? $(\mathrm{No}=0$; yes $=1)$ \\
\hline & Column 1 & Column2 & Column3 & Column 4 & Column 5 & Column 6 \\
\hline $\begin{array}{l}\text { Using an improved } \\
\text { variety }\end{array}$ & & & & & - & \\
\hline Row planting & & & & & & \\
\hline $\begin{array}{l}\text { Thinning during first } \\
\text { weeding }\end{array}$ & & & & & (n) & \\
\hline $\begin{array}{l}\text { Appliance of } \\
\text { chemical fertilizer }\end{array}$ & & & & & & \\
\hline $\begin{array}{l}\text { Micro-dosing of } \\
\text { fertilizer }\end{array}$ & & & & & $\cdots$ & \\
\hline $\begin{array}{l}\text { Appliance of } \\
\text { manure }\end{array}$ & & & & & $\ldots$ & \\
\hline Crop rotation & & & & & (n) & 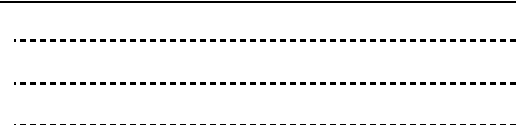 \\
\hline \multicolumn{7}{|c|}{$\begin{array}{l}\text { If you do row planting, how much space do you leave between the rows? } \\
\text { If you thin during weeding, how much space do you leave between the plants? } \\
\text { If you do crop rotation in finger millet production, with which crops do you rotate finger millet? }\end{array}$} \\
\hline
\end{tabular}


Constraints and opportunities of finger millet production

a) In the past five years, have you increased or decreased your finger millet area? Increased $(=1) \quad$ ) Decreased $(=2)(\quad) \quad$ Stayed the same $(=3) \quad(\quad)$

b) Would you like to increase your finger millet area in the coming years? No( $)$ yes( )1

c) What are the three main constraints for an increase in finger millet production area? (e.g. lack of labor, lack of land, priority of other crops, no seeds available).

d)

\begin{tabular}{|c|c|c|c|}
\hline \multicolumn{4}{|c|}{ Constraints (Codes A), start with the most important constraint! } \\
\hline \multicolumn{4}{|c|}{ 1) } \\
\hline \multicolumn{4}{|l|}{ 2) } \\
\hline \multicolumn{4}{|l|}{ 3) } \\
\hline \multicolumn{4}{|l|}{ Codes A: } \\
\hline Lack of labor & 1 & Priority of other crops & 4 \\
\hline Lack of land & 2 & Other & 5 \\
\hline No good seeds available & 3 & Other & 6 \\
\hline
\end{tabular}

e) What are the three main constraints in increasing finger millet yields? Start with the most important constraint (e.g. lack of capital for inputs, blast, striga, birds, lack of access to good seeds, erratic rainfall, lack of fertilizer, poor soils).

\begin{tabular}{|c|c|c|c|}
\hline \multicolumn{4}{|c|}{ Constraints (Codes A), start with the most important constraint! } \\
\hline \multicolumn{4}{|l|}{ 1) } \\
\hline \multicolumn{4}{|l|}{ 2) } \\
\hline \multicolumn{4}{|l|}{ 3) } \\
\hline \multicolumn{4}{|l|}{ Codes A: } \\
\hline Lack of capital for inputs & 01 & Erratic rainfall & 06 \\
\hline Blast & 02 & Lack of fertilizer & 07 \\
\hline Striga & 03 & Poor soils & 08 \\
\hline Birds & 04 & Other & 09 \\
\hline Lack of access to good seeds & 05 & Other & 10 \\
\hline
\end{tabular}

f) If you compare finger millet to maize, what are the five main disadvantages and the five main advantages of finger millet? Use codes $A$ and start with the most important advantage / disadvantage!

\begin{tabular}{|c|c|c|c|}
\hline \multicolumn{2}{|c|}{$\begin{array}{l}\text { Main advantages of finger millet compared } \\
\text { to maize }\end{array}$} & \multicolumn{2}{|c|}{$\begin{array}{l}\text { Main disadvantages of finger millet compared to } \\
\text { maize }\end{array}$} \\
\hline \multicolumn{2}{|l|}{ 1) } & \multicolumn{2}{|l|}{ 1) } \\
\hline \multicolumn{2}{|l|}{ 2) } & \multicolumn{2}{|l|}{ 2) } \\
\hline \multicolumn{2}{|l|}{ 3) } & \multicolumn{2}{|l|}{ 3) } \\
\hline \multicolumn{2}{|l|}{ 4) } & \multicolumn{2}{|l|}{ 4) } \\
\hline \multicolumn{2}{|l|}{ 5) } & \multicolumn{2}{|l|}{ 5) } \\
\hline \multicolumn{2}{|l|}{ Codes A: } & $\begin{array}{l}\text { yield potential } \\
\text { nutritional value }\end{array}$ & \\
\hline labor requirements & 02 & (e.g. for diabetics, pregnant women) & 07 \\
\hline resistance to pests / diseases & & taste & 08 \\
\hline (e.g. striga, blast) & 03 & marketing opportunities / market prices & 09 \\
\hline adaptability to erratic rainfall & 04 & others & 10 \\
\hline adaptability to poor soils & 05 & others & 11 \\
\hline
\end{tabular}




\section{Sales of crops, crop products and crop residues}

In this section, we would like you to list your sales of crops, crop products, and crop residues. Please list your sales of crops, crop residues and processed crop products in Table 10.1. Do not list your finger millet sales, we will ask for them later!

\section{Table 10.1: Sales of crops (other than finger millet) in 2011}

\begin{tabular}{|c|c|c|c|c|c|c|c|c|c|c|c|c|}
\hline \multirow{2}{*}{\begin{tabular}{|l} 
Crop code (if sale of \\
residue put ' $r$ ' in brackets, \\
if sale of processed crop \\
product put ' $p$ ' in brackets)
\end{tabular}} & \multicolumn{3}{|c|}{$\begin{array}{l}\text { Total harvest of that } \\
\text { crop in } 2011 \text { (longrain } \\
\text { plus shortrain!) }\end{array}$} & \multirow[t]{2}{*}{$\begin{array}{l}\text { Months of } \\
\text { sale }\end{array}$} & \multicolumn{2}{|c|}{ Quantity sold } & \multicolumn{2}{|c|}{ Av. selling price } & \multirow{2}{*}{$\begin{array}{l}\text { Mainly sold by } \\
\text { which hh } \\
\text { member? (hh } \\
\text { member codes) }\end{array}$} & \multirow[t]{2}{*}{$\begin{array}{l}\text { Main buyer } \\
\text { (codes } A \text { ) }\end{array}$} & \multirow{2}{*}{$\begin{array}{l}\text { distance } \\
\text { that you } \\
\text { had to } \\
\text { travel }(\mathrm{km})\end{array}$} & \multirow[t]{2}{*}{$\begin{array}{l}\text { travel costs and } \\
\text { other costs of } \\
\text { selling (KSh) }\end{array}$} \\
\hline & No. & \multicolumn{2}{|c|}{ Unit code } & & No. & Unit & $\begin{array}{l}\text { Price } \\
\text { (KSh) }\end{array}$ & $\begin{array}{l}\text { Unit } \\
\text { code }\end{array}$ & & & & \\
\hline & & & & & & & & & & & & \\
\hline & & & & & & & & & & & & \\
\hline & & & & & & & & & & & & \\
\hline & & & & & & & & & & & & \\
\hline & & & & & & & & & & & & \\
\hline & & & & & & & & & & & & \\
\hline & & & & & & & & & & & & \\
\hline & & & & & & & & & & & & \\
\hline & & & & & & & & & & & & \\
\hline & & & & & & & & & & & & \\
\hline & & & & & & & & & & & & \\
\hline & & & & & & & & & & & & \\
\hline & & & & & & & & & & & & \\
\hline & & & & & & & & & & & & \\
\hline & & & & & & & & & & & & \\
\hline \multicolumn{13}{|l|}{ Codes A } \\
\hline \multirow{7}{*}{\multicolumn{2}{|c|}{$\begin{array}{l}\text { neighbor / other farmer / family } \\
\text { local trader } \\
\text { market } \\
\text { local processor (e.g. local brewer) }\end{array}$}} & 1 & \multicolumn{9}{|c|}{ Institution (e.g. hospital, orphanage, NGO, research institute), name } & 05 \\
\hline & & 2 & \multicolumn{9}{|c|}{ Institution (e.g. hospital, orphanage, NGO, research institute), name } & 06 \\
\hline & & 3 & \multicolumn{9}{|c|}{ large company (e.g. exporting / processing company, supermarket chain), name. } & 07 \\
\hline & & 4 & \multirow{2}{*}{\multicolumn{9}{|c|}{$\begin{array}{l}\text { large company (e.g. exporting / processing company, supermarket chain), name } \\
\text { Through a group (Group code: }\end{array}$}} & 08 \\
\hline & & & & & & & & & & & & 09 \\
\hline & & & \multicolumn{9}{|c|}{ Through a group (Group code: } & 10 \\
\hline & & & \multicolumn{9}{|c|}{ Other } & 11 \\
\hline
\end{tabular}




\section{Finger millet marketing practices and constraints}

You've listed all your sales of crops, crop products and crop residues in the last section. In this section, we would like to have some more details on your finger millet marketing arrangements. Please list all your buyers of finger millet, finger millet residues, and finger millet products (e.g. finger millet beer, finger millet cakes).

\section{Table 11.1: Finger millet marketing}

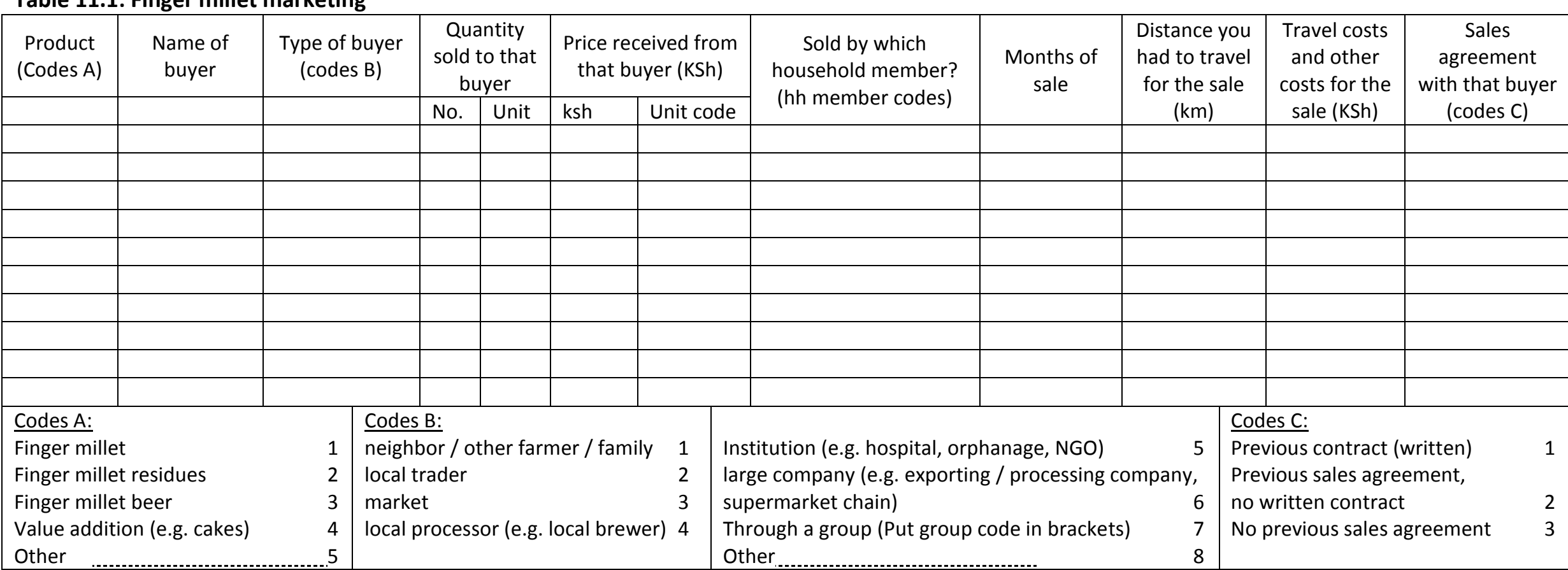

If you have a written contract or a previous sales agreement for finger millet or a finger millet product, please specify (no=0; yes=1):

\begin{tabular}{|c|c|}
\hline The contract guarantees an minimum price & $\begin{array}{l}\text { The contract includes specific quality requirements from your } \\
\text { part }\end{array}$ \\
\hline The contract has a fixed price agreement & Other: \\
\hline The guarantees a minimum selling quantity & Other: \\
\hline
\end{tabular}

Do you have any contracts or previous sales agreements for other products?

If yes, for which products?

no $(10 \quad$ yes $(\quad) 1$


To know more about how satisfied you are with your finger millet marketing possibilities, please write down the name of your main finger millet buyer and indicate how much you agree with the following statements in Table 11.2.

Name of the buyer:

\section{(Enumerators read answers loud!)}

Table 11.2 Satisfaction with marketing options

\begin{tabular}{|l|l|l|l|}
\hline & $\begin{array}{l}\text { I completely } \\
\text { agree }\end{array}$ & $\begin{array}{l}\text { I partly } \\
\text { agree }\end{array}$ & $\begin{array}{l}\text { I do not } \\
\text { agree }\end{array}$ \\
\hline This buyer is generally trustworthy. & & & \\
\hline The buyer pays good prices. & & & \\
\hline The buyer does never delay his / her payment. & & \\
\hline $\begin{array}{l}\text { The buyer tries to cheat when measuring the finger millet } \\
\text { quantity. }\end{array}$ & & & \\
\hline $\begin{array}{l}\text { The buyer tries to reduce the selling price by claiming that the } \\
\text { quality of my product is bad. }\end{array}$ & & & \\
\hline $\begin{array}{l}\text { The buyer tries to charge me too much for the transport or } \\
\text { other services. }\end{array}$ & & & \\
\hline I am generally satisfied with this buyer. & & \\
\hline $\begin{array}{l}\text { I am generally not satisfied with this buyer but do not have } \\
\text { better marketing options }\end{array}$ & & \\
\hline $\begin{array}{l}\text { The buyer buys finger millet in too small quantities, it would } \\
\text { be better for me to sell in larger quantities }\end{array}$ & & \\
\hline
\end{tabular}

\section{Post-harvest handling}

We are now interested in the costs and the labor requirements of your post-harvest handling of maize and millet (threshing, milling, dehulling, winnowing, shelling). Please estimate your total costs and labor requirements in Table 12. 1.

Table 12.1: Post-harvest handling

\begin{tabular}{|l|l|l|l|l|l|l|l|}
\hline & $\begin{array}{l}\text { Quantity of } \\
\text { maize / finger } \\
\text { millet in 2011 }\end{array}$ & $\begin{array}{l}\text { Labor input for all post- } \\
\text { harvest handling activities } \\
\text { (days) }\end{array}$ & $\begin{array}{l}\text { Costs for all post-harvest } \\
\text { handling activities, e.g. for } \\
\text { transport to mill, hiring } \\
\text { machines (KSh) }\end{array}$ \\
\hline & No. & Unit & 1 & 2 & 3 & 4 & \\
\hline Maize & & & & & & & \\
\hline Finger millet & & & & & & & \\
\hline $\begin{array}{l}\text { For the labor input: } \\
\text { 1= days of family labor } \\
\text { 3= days of exchange labor }\end{array}$ \\
2= hh member with largest work contribution (hh member codes) \\
4= days of wage labor
\end{tabular}




\section{Livestock production}

Please give us some information on your livestock holdings and the in- and outputs of your livestock production in 2011.

Table 13.1: Livestock

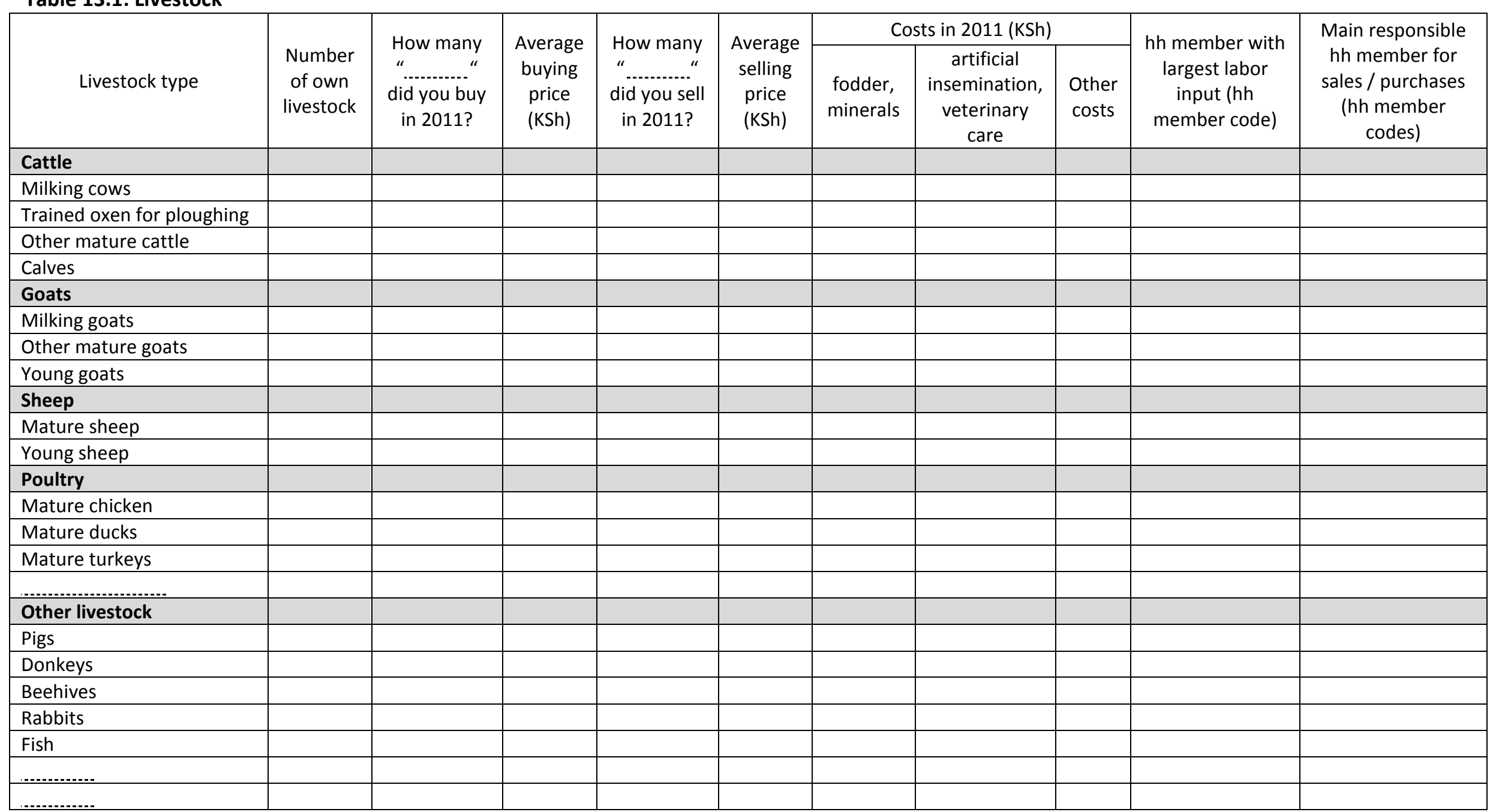


Table 13.2: livestock products and sales in 2011

\begin{tabular}{|c|c|c|c|c|c|c|}
\hline \multirow{2}{*}{ Livestock product } & \multicolumn{2}{|c|}{$\begin{array}{l}\text { Average number of units } \\
\text { produced per month }\end{array}$} & \multicolumn{2}{|c|}{$\begin{array}{l}\text { Average number of } \\
\text { units sold per month }\end{array}$} & \multirow{2}{*}{$\begin{array}{l}\text { Average } \\
\text { selling price } \\
\text { per unit } \\
\text { (KSh) }\end{array}$} & \multirow{2}{*}{$\begin{array}{l}\text { hh member who sold } \\
\text { the largest share of } \\
\text { this product (hh } \\
\text { member codes) }\end{array}$} \\
\hline & No. & Unit code & No. & Unit code & & \\
\hline \multicolumn{7}{|c|}{ 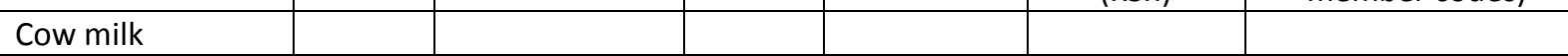 } \\
\hline \multicolumn{7}{|l|}{ Goats milk } \\
\hline \multicolumn{7}{|l|}{ Eggs (all poultry) } \\
\hline \multicolumn{7}{|l|}{ Honey (kg) } \\
\hline \multicolumn{7}{|l|}{ Wool } \\
\hline \multicolumn{7}{|l|}{ Skin } \\
\hline \multicolumn{7}{|l|}{ Manure } \\
\hline Others & & & & & & \\
\hline Others & & & & & & \\
\hline
\end{tabular}

Have you rented out animals (e.g. oxen for ploughing) in 2011?

No $(=01) \quad(\quad) \quad$ Yes $(=2)(\quad) \quad$ for ......... days and ........................ KSh per day (average)

\section{Access to services}

Table 14.1: Access to credits

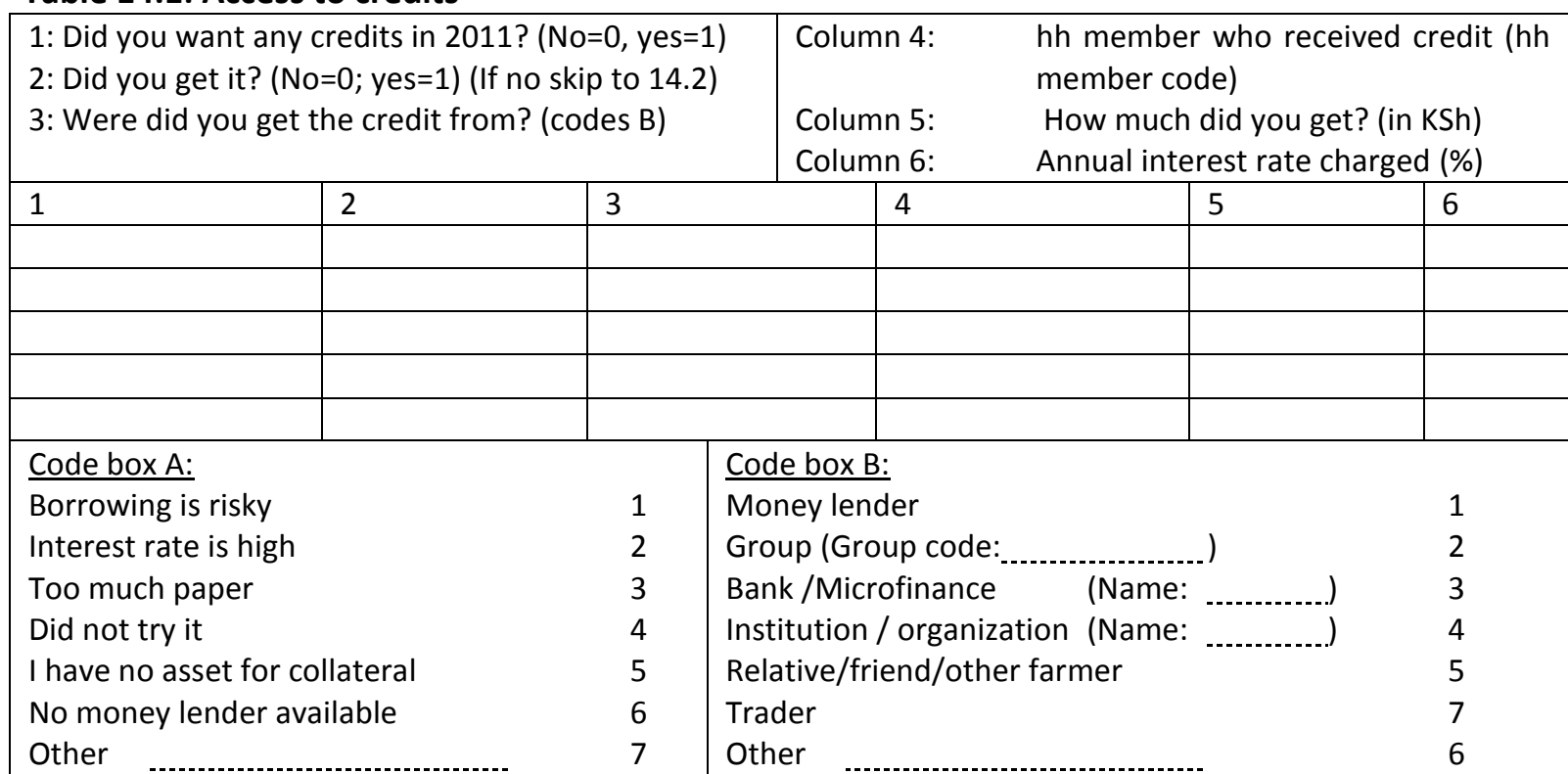

\section{2: Cell phones}

a) Does your household use any cell phone? No ( ) 0 yes ( )1 (If no skip to 14.3)

b) Which hh members have an own cell phone? (hh member codes).

c) What do you use your cell phone for?

\begin{tabular}{|l|l|l|l|}
\hline Do you use a cell phone for communication with... & No & Yes & If yes, how often? (Codes A) \\
\hline$\ldots$ other farmers? & & & \\
\hline$\ldots$ seed and other input traders? & & & \\
\hline$\ldots$ millet traders/buyers? & & & \\
\hline$\ldots$ extension services, NGOs, GOs? & & & \\
\hline$\ldots$ an agricultural information service? & & & \\
\hline$\ldots$ a financial transaction service & \multicolumn{3}{|l|}{} \\
\hline Codes A: & At least once a month \\
Every day & Less than once a month \\
At least once a week & 2
\end{tabular}


If you don't use an agricultural information service, skip to section 14.3.

If you use an agricultural information service:

Name of the service:

Since when do you use it? (year)

Which household members are using it? (use hh member codes)

Type of information obtained by the service:

market prices

market prices specifically for finger millet

weather forecasts

information on current pests and diseases

information on current pests and diseases specifically for finger millet

Other

Other

\section{3: Extension and trainings}

Did your household receive any type of extension or training in the past five years?

No ( $)$ yes ( )1 (Shift to section 15 if no).

Please list all services received, these might also include field days or farmer field schools.

Table 14.3: Access to extension services and trainings

1: Type/purpose of extension service or training received in the past 5 years

2: Received from whom? (codes A)

3: Related to finger millet production? $(\mathrm{No}=0, \mathrm{Yes}=1)$

4: Related to maize production? ( $\mathrm{No}=0, \mathrm{Yes}=1$ )

5: Received by which hh member(s)? (hh member codes)

6: Received when?

7: How many days?

8: Costs (KSh)

\begin{tabular}{|c|c|c|c|c|c|c|c|}
\hline \multirow{2}{*}{1} & \multirow{2}{*}{2} & \multirow{2}{*}{3} & \multirow{2}{*}{4} & \multicolumn{2}{|c|}{6} & \multirow{2}{*}{7} & \multirow{2}{*}{8} \\
\hline & & & & Month & Year & & \\
\hline \multirow{2}{*}{\multicolumn{7}{|c|}{ (1) }} & \\
\hline \multirow{2}{*}{\multicolumn{8}{|c|}{ (1) }} \\
\hline & & & & & & & \\
\hline \\
\hline \multicolumn{8}{|c|}{$\ldots$} \\
\hline \multirow{2}{*}{\multicolumn{8}{|c|}{ Codes A: }} \\
\hline & & & & & & & \\
\hline \multicolumn{8}{|c|}{$\overline{\text { Received }}$ as individual farmer from } \\
\hline \multicolumn{4}{|c|}{ Received as individual farmer from } & \multicolumn{4}{|r|}{2} \\
\hline \multicolumn{3}{|c|}{ Received through group (group code: } & ..) from & \multicolumn{4}{|c|}{3} \\
\hline \multicolumn{3}{|c|}{ Received through group (group code: } & from & & & & 4 \\
\hline
\end{tabular}

If you did receive any trainings related to finger millet, have you changed your finger millet production system due to this training, e.g. tried a new variety, started row-planting, started to apply fertilizer?

No( $) 0 \quad$ yes ( )1

If yes, please specify: 


\section{Non-farm household income}

Please give us some information on your non-agricultural household income in 2011.

Table 15.1: Non-farm household income

\begin{tabular}{|c|c|c|c|}
\hline hh member (hh member codes) & $\begin{array}{c}\text { Type of income } \\
\text { (codes A) }\end{array}$ & $\begin{array}{c}\text { Income per month } \\
\text { (KSh) }\end{array}$ & $\begin{array}{c}\text { Total income in } 2011 \\
\text { (KSh) }\end{array}$ \\
\hline & & & \\
\hline & & & \\
\hline & & & \\
\hline & & & \\
\hline & & & \\
\hline & & & \\
\hline \multicolumn{4}{|l|}{ Codes A } \\
\hline \multicolumn{3}{|l|}{ Farm labour wages } & 1 \\
\hline \multicolumn{3}{|l|}{ Non-farm labour wages } & 2 \\
\hline \multicolumn{4}{|l|}{ Non-farm business NET income } \\
\hline \multicolumn{3}{|c|}{ (e.g. grain milling/trading, shop, handicraft, charcoal making, sales of firewood) } & 3 \\
\hline \multicolumn{3}{|c|}{ Pension income } & 4 \\
\hline \multicolumn{3}{|c|}{ Remittances (sent from non-resident family and relatives living elsewhere) } & 5 \\
\hline \multicolumn{3}{|l|}{ Marriage Gifts } & 6 \\
\hline \multicolumn{3}{|l|}{ Rental property (other than land) } & 7 \\
\hline \multicolumn{3}{|l|}{ Other: $\ldots$} & 8 \\
\hline \multicolumn{3}{|l|}{ Other: } & 9 \\
\hline
\end{tabular}

\section{Housing}

Please give us some information on your physical household assets concerning housing, transportation means,
a) Size of the house $\left(\mathrm{m}^{2}\right)$
b) Number of rooms in the house
c) Main construction material of the exterior wall
d) Main construction material of the roof
e) Main construction material of the floor
f) Does the house have electricity?
g) Do you have a landline telephone?

h) Is the house your own property, rented from someone, or borrowed from someone?

i) What type of sanitary facilities do you use (e.g. private or shared pit latrine)?

j) What is your primary source of drinking water (e.g. pump, community well, river/stream)?

k) What do you use as cooking facility (e.g. open fire, improved fireplace, charcoal/ wood/ kerosene stove)? 


\section{Other physical household assets}

Table 17.1: Which other physical household assets do you own?

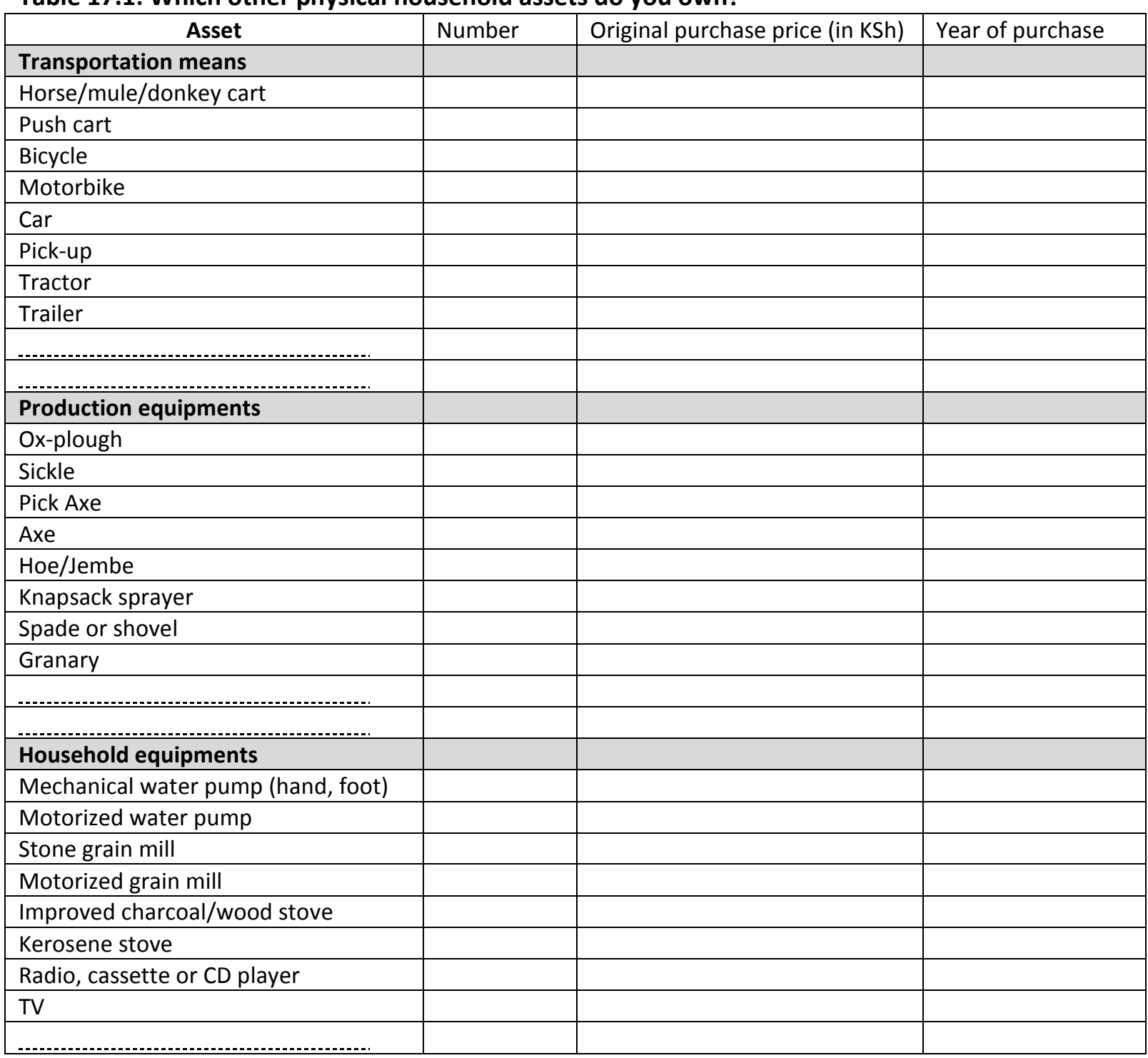

\section{Household's current situation}

If you compare your household's current income and asset situation with the household's situation 10 years ago, has it become poorer or wealthier in the past 10 years?

What do you think, what made your household poorer or wealthier in the past 10 years? 


\section{Food security}

In this last section of the questionnaire, we would like to learn about your household's situation in terms of food security. First of all, we would like to know about your consumption of staple crops throughout the last year.

Table 19.1: Staple crop consumption

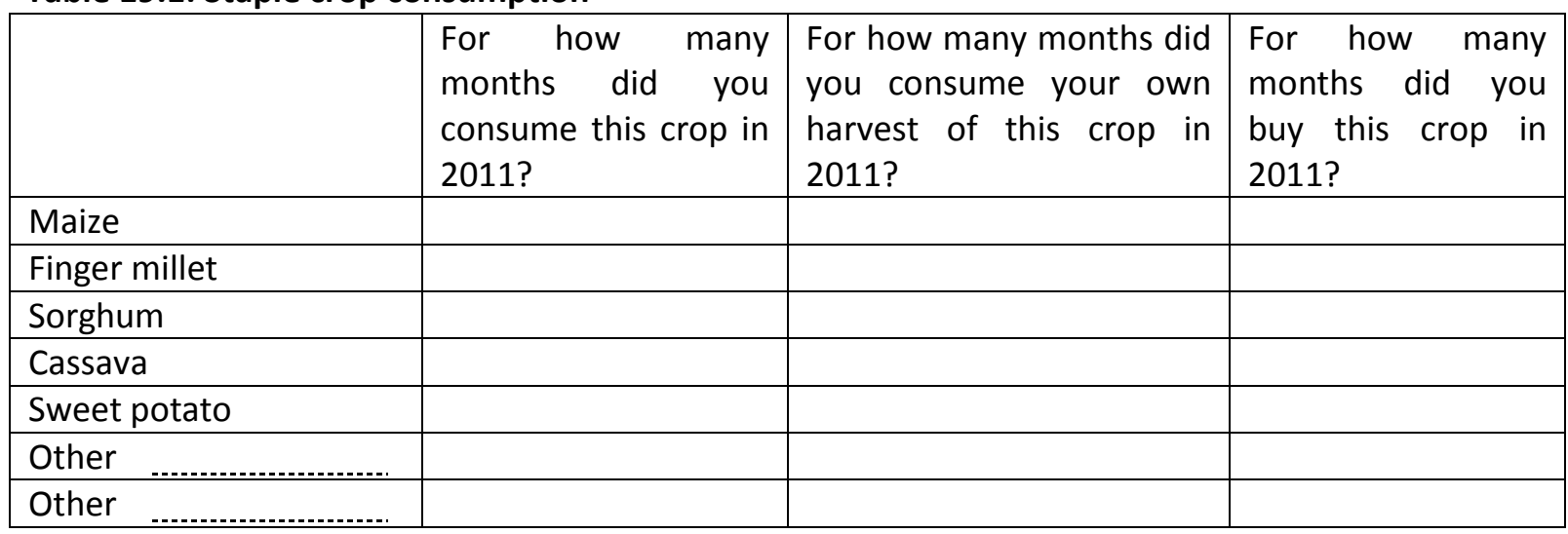

Which month(s) was / were the worst month in terms of access to enough food in 2011?

Table 19.2: Which of the following measures did you have to take during the mentioned month(s)? (Enumerators read answers loud!)

\begin{tabular}{|l|l|l|l|l|l|}
\hline $\begin{array}{l}\text { Because food is not enough, or money to buy food is } \\
\text { not enough, we had to ... }\end{array}$ & $\begin{array}{l}\text { Every } \\
\text { day }\end{array}$ & $\begin{array}{l}3-6 \\
\text { times a } \\
\text { week }\end{array}$ & $\begin{array}{l}1-2 \\
\text { times a } \\
\text { week }\end{array}$ & $\begin{array}{l}\text { Less than } \\
\text { once a } \\
\text { week }\end{array}$ & Never \\
\hline ...rely on less preferred and less expensive foods? & & & & & \\
\hline ...borrow food, or borrow money to buy food? & & & & & \\
\hline ...purchase food on credit? & & & & & \\
\hline $\begin{array}{l}\text {...rely on help from relative or friend outside } \\
\text { household (including remittances)? }\end{array}$ & & & & \\
\hline ...limit portions at mealtimes? & & & & & \\
\hline $\begin{array}{l}\text {...ration the little money you have to household } \\
\text { members to buy street foods? }\end{array}$ & & & & \\
\hline ...limit your own intake to ensure child gets enough? & & & & & \\
\hline ...reduce number of meals eaten in a day? & & & & & \\
\hline ...skip whole days without eating? & & & & & \\
\hline
\end{tabular}


In this last table, we would like to know more about your food consumption in the past 7 days. For each of the categories (e.g. cereals), write down the 5 crops that you have consumed most in the past 7 days.

Table 19.3: Food consumption during the past 7 days

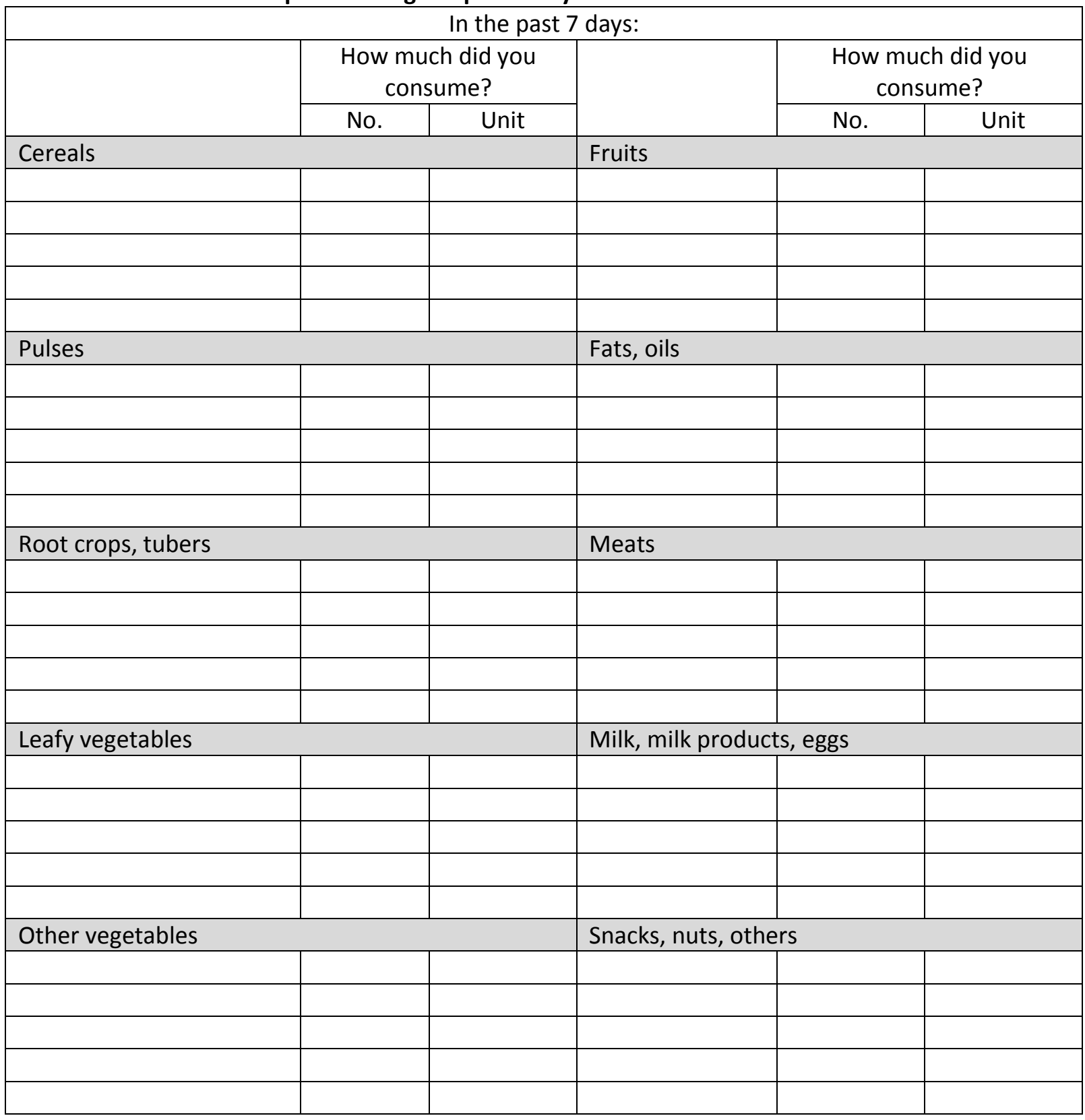


Unit Codes / crop codes

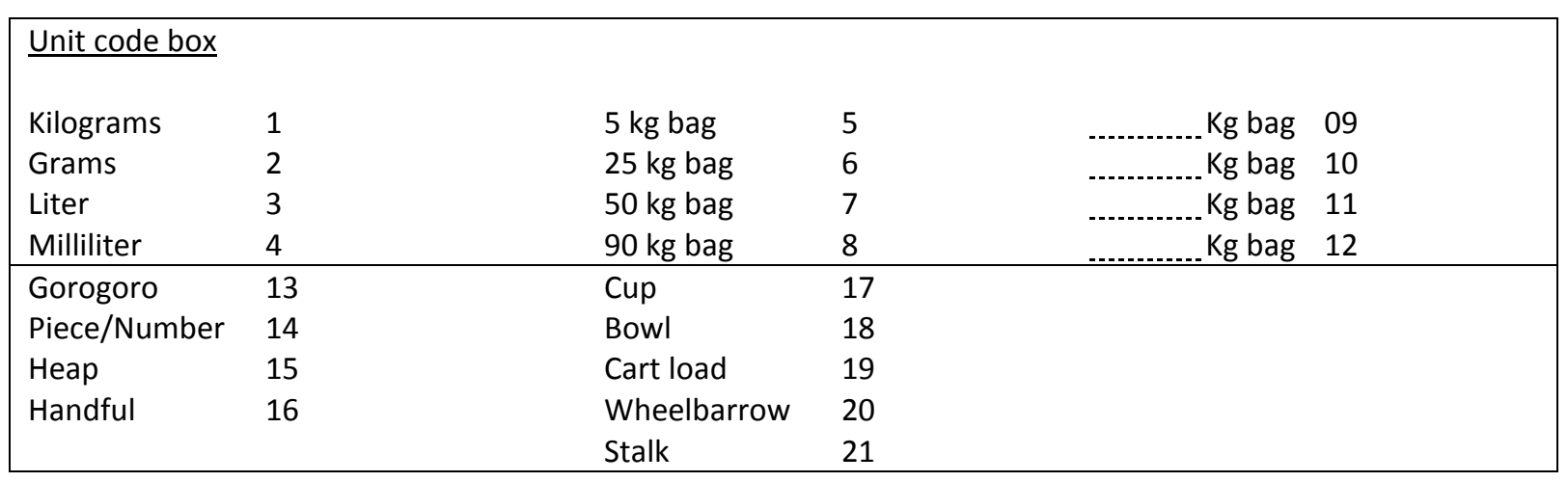

\begin{tabular}{|c|c|c|c|c|c|}
\hline \multicolumn{6}{|l|}{ Crop code box } \\
\hline \multicolumn{2}{|l|}{ Cereals } & \multicolumn{2}{|l|}{ Pulses } & \multicolumn{2}{|c|}{ Root crops, tubers, vegetables } \\
\hline Maize & 01 & Groundnut & 11 & Cassava & 23 \\
\hline Finger Millet & 02 & Soybean & 12 & Sweet potato & 24 \\
\hline Sorghum & 03 & Other beans & 13 & Onion & 25 \\
\hline Other millets & 04 & Pigeonpea & 14 & Pepper & 26 \\
\hline \multirow[t]{2}{*}{ Rice } & 05 & Cowpea & 15 & Tomato & 27 \\
\hline & 06 & Chickpea & 16 & Kale & 28 \\
\hline & 07 & Other peas & 17 & Carrot & 29 \\
\hline & 08 & & 18 & & 30 \\
\hline & 09 & & 19 & & 31 \\
\hline \multirow[t]{3}{*}{ (....................... } & 10 & & 20 & .. & 32 \\
\hline & & & 21 & & 33 \\
\hline & & & 22 & $\ldots$ & 34 \\
\hline \multicolumn{2}{|l|}{ Oil crops } & \multicolumn{2}{|c|}{ Perennial crops } & \multicolumn{2}{|c|}{ Fodder legumes } \\
\hline Sunflower & 24 & Sugar cane & 32 & Lablab & 44 \\
\hline \multirow[t]{11}{*}{ Oil palms } & 26 & Coffee & 33 & Clover & 45 \\
\hline & 27 & Tobacco & 34 & Vetch & 46 \\
\hline & 28 & Banana & 35 & Alfalfa & 47 \\
\hline & 29 & Orange & 36 & Sesbania & 48 \\
\hline & 30 & Mango & 37 & & 49 \\
\hline & \multirow[t]{6}{*}{31} & Passion fruit & 38 & & 50 \\
\hline & & & 39 & & 51 \\
\hline & & & 40 & & 52 \\
\hline & & & 41 & & 53 \\
\hline & & & 42 & & \\
\hline & & & 43 & & \\
\hline
\end{tabular}

